(2⿳⺈冂大

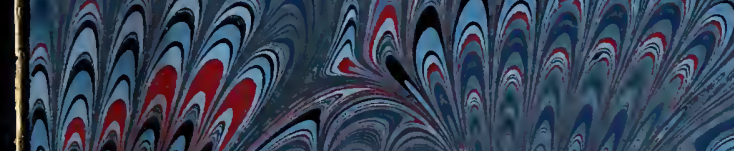

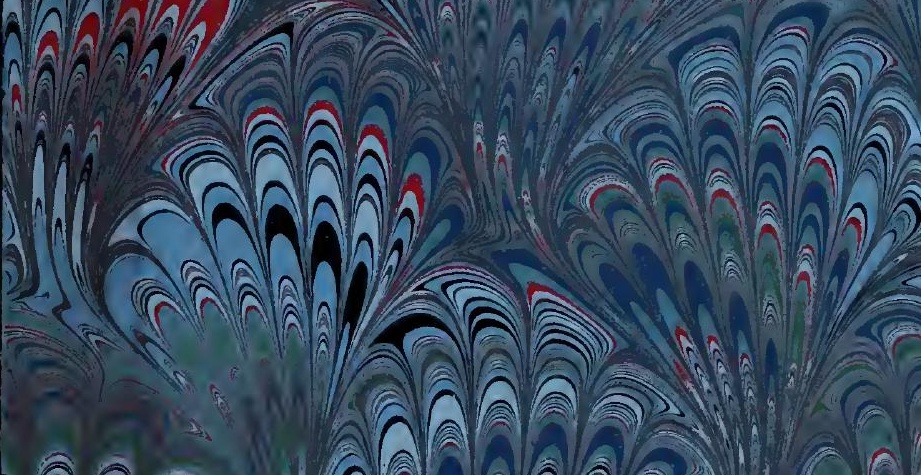

ลล่ล จิ)

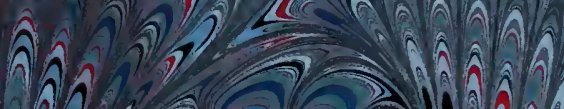

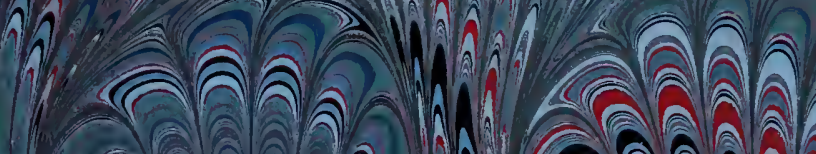

M

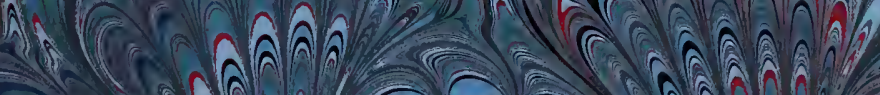
$\sqrt{\text { (2) }}$ (

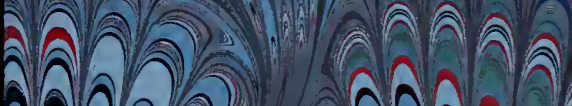

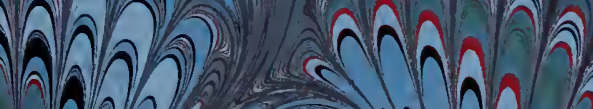
(6) 1. 2 an 2 Whan 











\title{
MONOGRAPH Y
}

OF THE

\section{F A M I Y U N I O I D}

\author{
OR NAIADES OF LAMARCK,
}

(FRESH WATER BIVALVE SHELLS,)

OF

NORTH AMERICA,

ILLUSTRATED BY FIGURES DRAWN ON STONE FROM NATURE.

$$
\text { BY T. A. CONRAD, }
$$

CURAToR of THE ACADEMY OF NATURAL SCIENCES OF PHILADELPHIA, hoNoRARY MEMBER OF THE GEOLOGICAL SOCIETY OF PENNSYLVANIA.

PHILADELPHIA :

J. DOBSON, 108 CHESNUT STREET.

1836. 
A2196

E. F. DoRSEY, Printer,
12 Library Street. 
CHARLES A. POULSON, Es a. Member of the Acadcmy of Natural Sciences of Philadelphia, \&॰c.

THIS BOOK IS DEDICATED,

AS A SLIGHT TRIBUTE OF ESTEEM,

BY HIS OBLIGED FRIEND,

THE AUTHOR. 



\section{MONOGRAPH Y}

OF THE

\section{F A M L Y U NTON I D E.}

\section{UNIO.}

GENERIC CHARACTER.

Shell equivalved, inequilateral: cardinal teeth two in each valve, irregular, generally striated, simple or biparted; an elongated lamelliform tooth on the posterior hinge margin of the right valve, and two similar teeth on the corresponding margin of the left valve: muscular impressions two principal ones in each valve.

\section{OBSERVATIONS.}

Mr. Say justly remarks, that, "in North America, the shells of this genus excel those of any other country in magnitude, beauty, and diversity of species." The rivers of Tennessee have furnished the most beautiful specimens of many species common to the western waters. The Ohio or Mississippi has 
not hitherto furnished a single species existing in tide waters which flow into the Atlantic; and the only shell of this character is the Alasmodonta marginata, $\mathrm{S}_{\mathrm{AY}}$.

The shells of this genus may be divided into two groups, the "winged" and "not winged," as Mr. Sowerby has proposed for the whole family of UNionide. 'The former are included in the genus Symphynota, of $\mathrm{Mr}$. Lea, which we cannot adopt, because, as Ferussac justly remarks, "in the same family generic characters should be taken from the same parts;" thus the other genera are formed from the absence or arrangement of the hinge teeth, whilst $\mathbf{S y m p h y n o t a ,}$ without any regard to the hinge, is constructed from a testaceous connexion of the valves, which Ferussac observes is "almost an organic character among the Acephala which have the mantle completely closed near the hinge margin, at least in young shells."

Dr. Kirtland has made some interesting remarks on the sexes of this family, in which he has proved them to be distinct, in the opinion of many conchologists; and the sex can be ascertained by the form of the shell. Almost every species has two prominent varieties of form, one of which is shorter and more ventricose than the other, which is happily explained by the observations of the intelligent author of the essay referred to.*

*Vide Silliman's Journ. vol. xxvi. p. 117 . 


$$
\begin{gathered}
59^{4} \\
c^{16}
\end{gathered}
$$



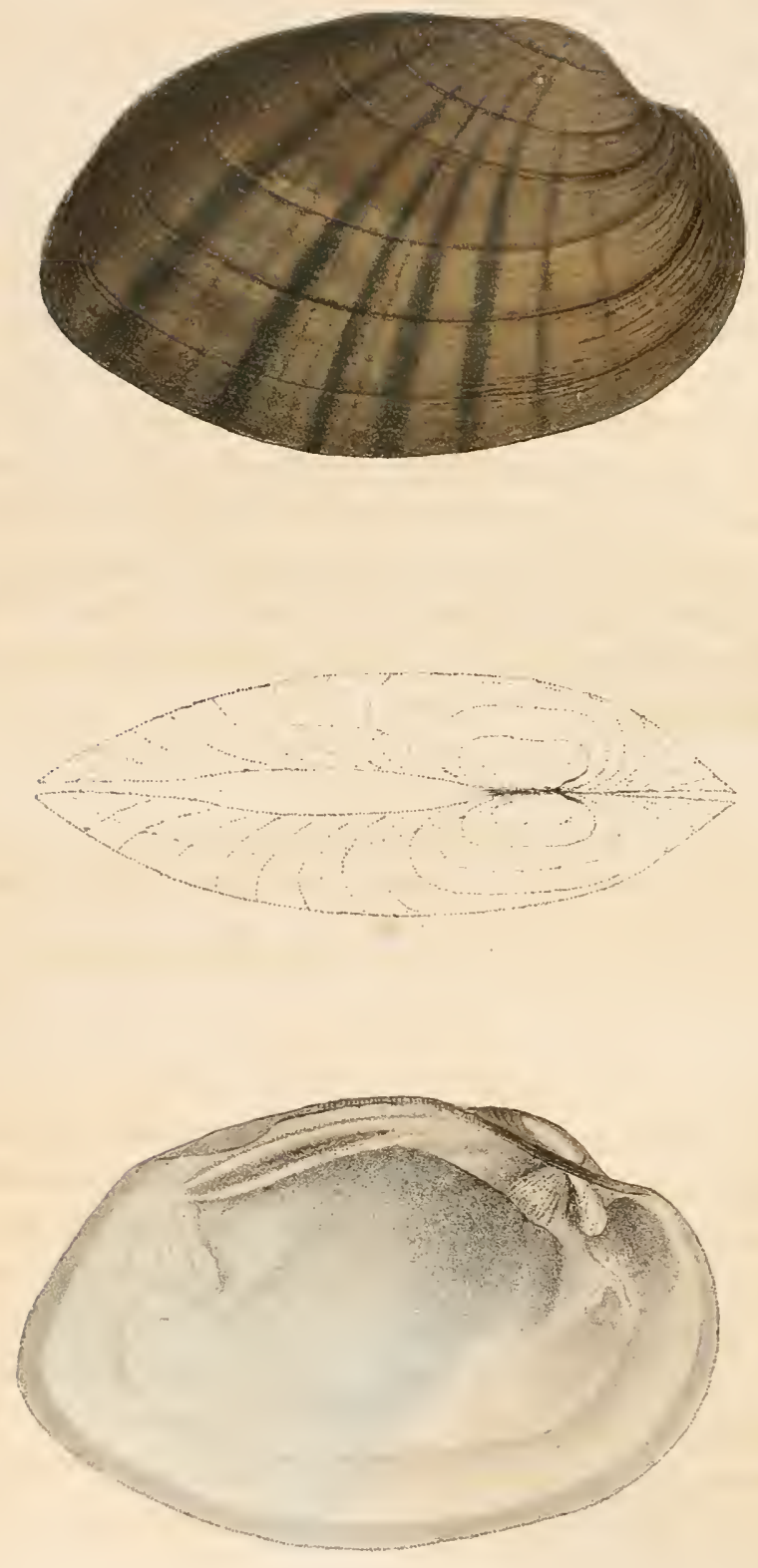

Unio fasicalus, Raf. 


\section{UNIO FASCIATUS.}

\section{Plate I.}

\section{DESCRIPTION.}

Shell elliptical, compressed, yellowish olive, with broad dark green rays, and a few intermediate narrow rays; umbo slightly compressed, little prominent; anterior side short; ligament margin scarcely curved, slightly declining; posterior margin obliquely truncated; umbonial slope abruptly rounded; submargin slightly furrowed; basal margin protruding a little near and behind the middle; within white; cardinal teeth thick, direct; margin thin, showing the exterior rays.

\section{SYNONYMES.}

U. Fasciatus, Raf. Ann. gen. des Sc. Pliys. vol. v. p. 28. Poulson's translation, p. 20. Say, Amer. Concl. No. 6. Ferussac, Mag. de Zool.

U. carinatus, Burnes. Silliman's Journal, vol. vi. p. 126.

Cab. A. N. S. No. 1020.

\section{OBSEPVATIONS.}

This shell has been considered a variety of cariosus by some conchologists, but it is invariably more ponderous and compressed, with very different markings and cardinal teeth. It is most nearly related to the crassus, $\mathrm{S}_{\mathbf{A} Y}$, but can be distinguished by its more elliptical outline, much broader and darker rays, and by the beaks being less nearly terminal. Ferussac gives carinatus, Barnes, as a synonyme to crassus, $\mathrm{S}_{\mathrm{AY}}$. Common in the western waters. The 
figure is from a specimen from the Scioto, given me by my friend, Dr. William Blanding.

\section{UNIO OVA'TUS.}

\section{Plate II.}

DESCRIPTION.

Shell subtriangular, rather thin, compressed anteriorly, inflated over the umbonial slope, which is profoundly angulated and subrectilinear; posterior slope flattened or slightly concave, much wrinkled; umbo inflated, prominent, sloping anteriorly, distant from the anterior margin; surface glabrous, olive-yellow; within bluish; cardinal teeth double in each valve, very oblique, compressed, elevated.

\section{SYNONYMES.}

U. ovatus, Say. Nicholson's Ency. (3d Amer. ed.) art. Conch. pl. ii. fig. 7. Lam. An. sans vert. vol. vi. p. 75. Cab. A. N. S. No. 1225.

\section{OBSERVATIONS.}

The great depression of the posterior slope distinguishes this species from the cardium, RAF. Old shells are produced posteriorly. It varies considerably in form; some specimens are compressed, others very ventricose, with rather broad radii over the whole disk. This variety is so dissimilar to the specimen figured, that I propose to designate it by a distinct name, terming it variety ornatus; it is common in the rivers of South Alabama. The species is common in the western waters. 

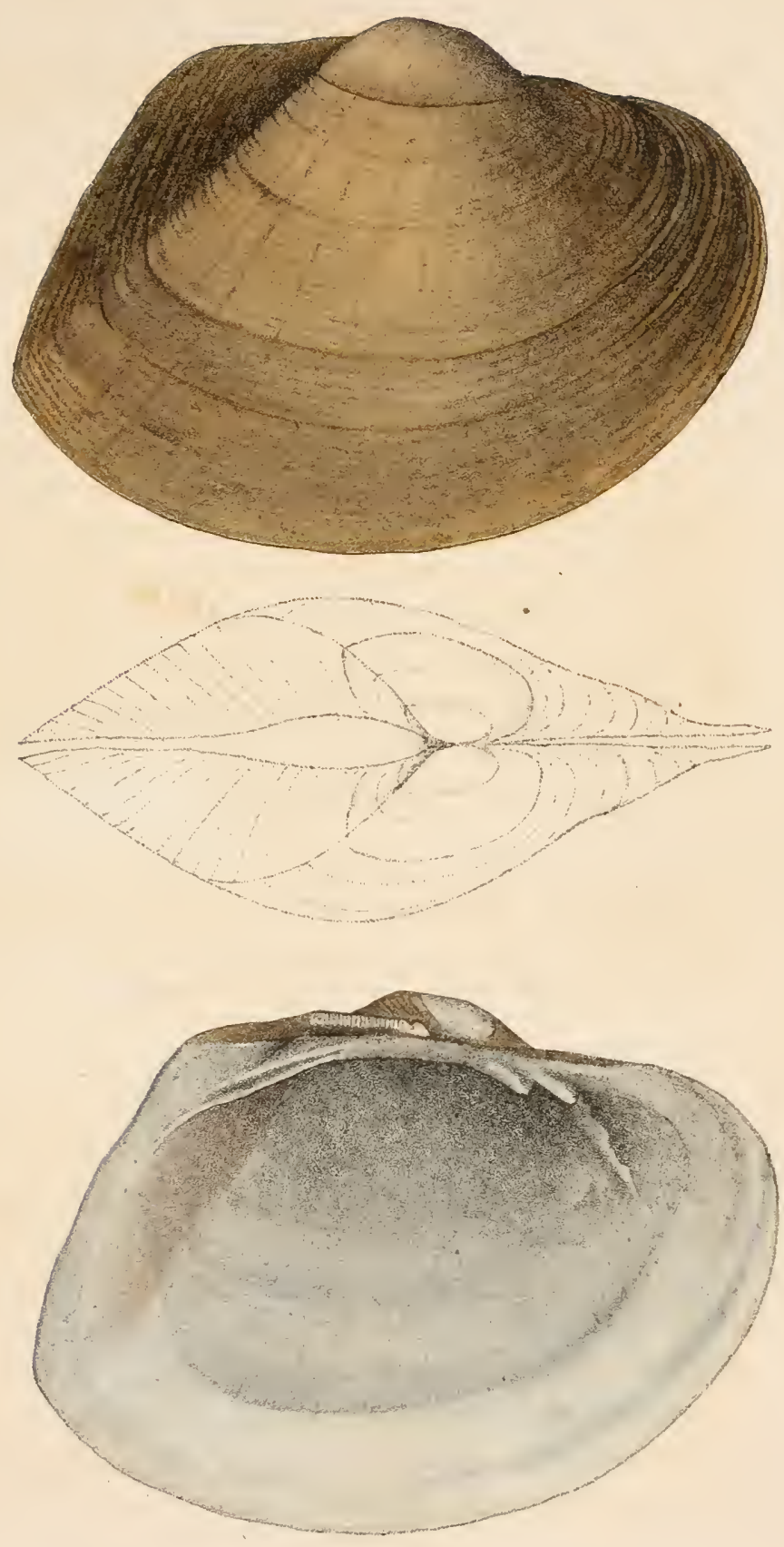

Unio ovatus, is ay. 



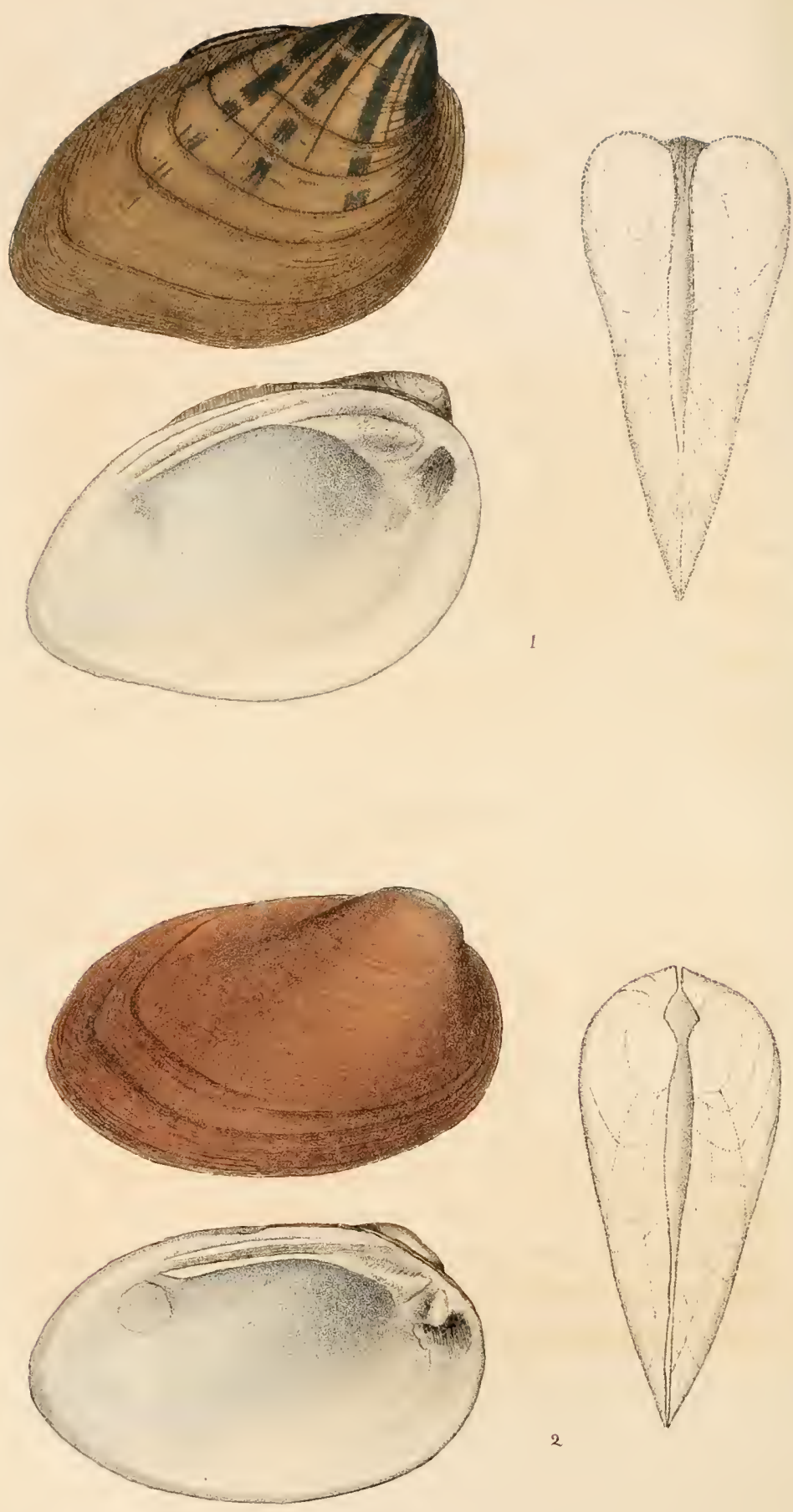

2

1. Unio claus, Lam, 2. Unio decisus, Lea. 


\section{UNIO CLAVA.}

Plate III.-Fig. 1.

DESCRIPTION.

Shell cuneiform, very oblique; posterior side produced, compressed, with an oblique furrow rapidly widening from the umbo; ligament margin arcuate, very oblique; umbo elevated, narrowed, inclining forwards; beaks curved to a point, terminal; epidermis wrinkled, olive-yellow or brownish, with interrupted rays over the umbo, disappearing with age; within white, very iridescent posteriorly; cardinal tooth in the left valve nearly parallel with the ligament margin.

SYNONYMES.

U. clava, Lam. An. sans vert. vol. vi. p. 74 .

U. scalenius, Raf. Ann. gen. des Sc. Phys. vol. v. p. 43. pl. ixxxi. fig. 24, 25. Poulson's trans. p. 47.

U. Modioliformis, Say.

Cab. A. N. S. No. 1117.

OBSERVATIONS.

A beautiful species when perfect, and common in the western rivers. With age the posterior side becomes greatly produced and compressed, and generally furnished with irregular indentations. Allied to $U$. oviformis, nob. and decisus, LEA. 


\title{
UNIO DECISUS.
}

\author{
Plate III.-Fig. 2.
}

DESCRIPTION.

Shell cuneiform, oblique; anterior margin obtusely rounded; posterior side produced, somewhat compressed, with a very oblique indistinct furrow, and irregular indentations, frequently obsolete; extremity angular; beaks nearly terminal, eroded; umbonial slope rectilinear, subangulated; epidermis finely wrinkled inferiorly, reddish-brown with obsolete brown narrow rays; within white.

\section{SYNONYMES.}

U. Decisus, Lea. 'Trans. Amer. Philos. Soc. new series, vol. iv. p. 92, pl. xii. fig. 23.

U. taitianus, $i b$. vol. v. p. 39 , pl. iv. fig. 11 . variety.

Cab. A. N. S. No. 1733.

\section{OBSERVATIONS.}

This species much resembles the preceding, but can always be distinguished by its broader and less oblique umbo, uniform absence of green rays, and by its rectilinear umbonial slope, but more especially by the posterior extremity, which is never so nearly on a line with the base as in the former shell, which with age is greatly produced and compressed, whilst the present species, when old, never becomes so; the cardinal teeth, also, are very different. Common in the Alabama river, and has hitherto been found only in the state of Alabama. 


\title{
UNIO REFLEXUS.
}

\author{
Plate IV.-Fig. 1.
}

DESCRIPTION.

Shell suboval, thick anteriorly; middle of the disks with a single row of distant elevated tubercles, about four in number; umbo not very prominent, submedial; umbonial slope subcarinated; posterior side slightly furrowed and emarginate at base; posterior slope flattened, with transverse undulations; posterior extremity truncated; within white; cardinal teeth large, direct, much sulcated.

Var. A. disks covered with small tubercles.

Var. B. epidermis blackish, nacre purple.

\section{SYNONYMES.}

U. Reflexus, Raf. Ann. gen. des Sc. Phys. vol. v. p. 40. Poulson's trans. p. 40. Say, Amer. Concls. No. 6. Ferussac, Mag. de Zool.

U. cornutus, Barnes. Silliman's Journ. vol. vi. p. 122. Cab. A. N. S. No. 1750 .

OBSERVATIONS.

Allied to the $\boldsymbol{U}$. flexuosus, but approaches nearest to $\boldsymbol{U}$. gibbosus, $\mathbf{R}_{\mathrm{AF}}$. yet may always be distinguished from that species by its suboval outline, and the regularity and prominence of its tubercles. The two varieties $I$ found in the Alabama river. The figure represents a tuberculated specimen. The species preserves its distinctive characters in very 
remote localities, specimens from south Alabama perfectly resembling others from the waters of Indiana.

\title{
UNIO FLEXUOSUS.
}

\author{
Plate IV.-Fig. ¿.
}

DESCRIPTION.

Shell subtriangular, bifurcated, swelling and subnodulous in the middle; posterior side with a wide oblique furrow; umbonial slope obtusely carinated; umbo flattened, prominent; epidermis with numerous slender rays; within white, cardinal teeth direct, sulcated; lateral teeth short and thick.

\section{SYNONYMES.}

U. flexuosus, Raf. Ann. gen. des Sc. Phys. vol. v. p. 40.

U. foliatus, Hildreth. Silliman's Journ. vol. xiv. p. 248, fig. 16.

Cab. A. N. S. No. 1050.

\section{OBSERVATIONS.}

A specimen of this shell in Mr. Poulson's cabinet was labelled by Rafinesque, whose description, under the name we have adopted, entirely accordis with the species before it has attained its profound bifurcation.

This singular species, when young, is smooth, and simply emarginate behind the middle. It approaches nearest to $\boldsymbol{U}$. gibbosus, $R_{A F}$. Not uncommon in the western rivers. 

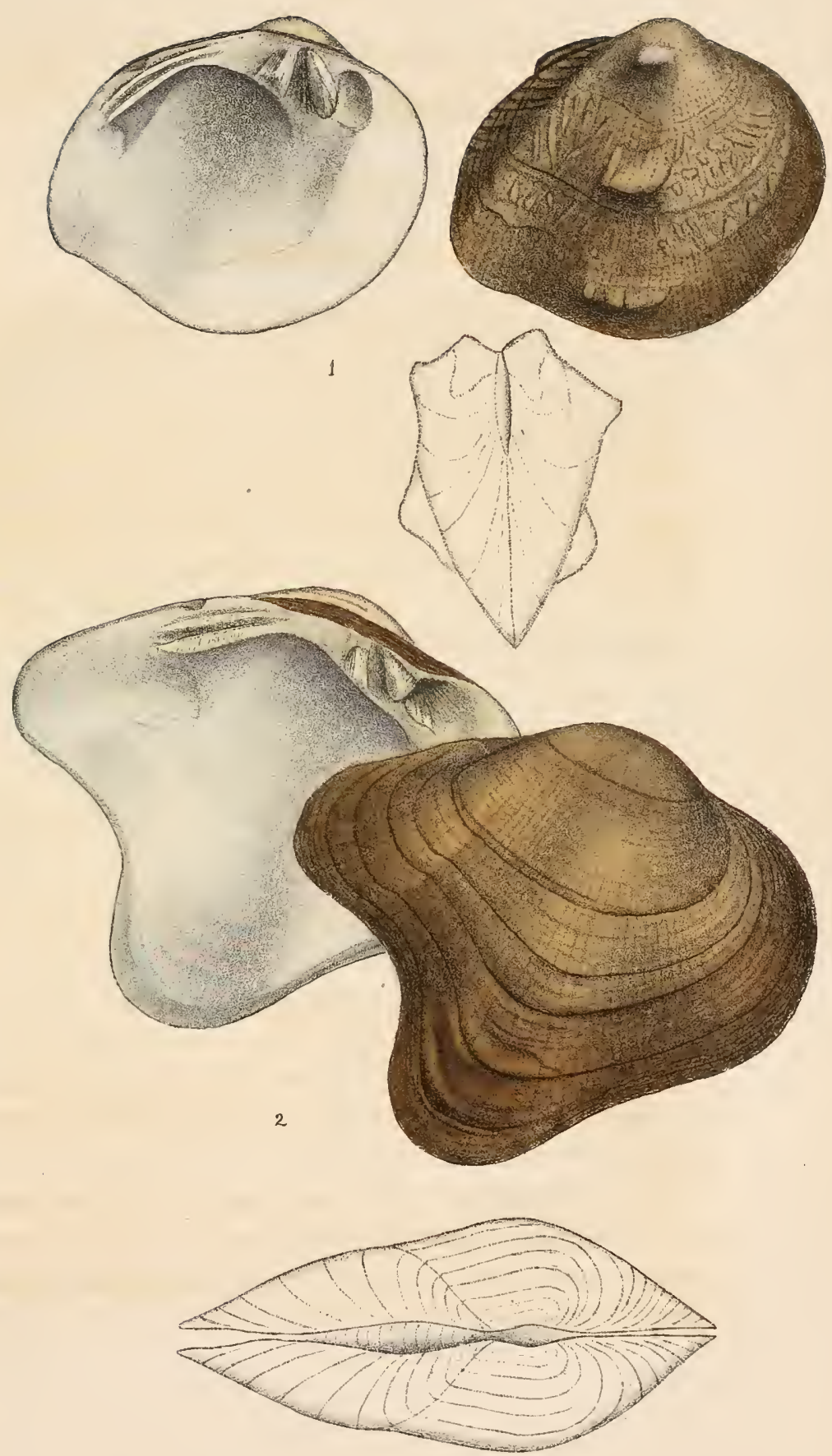

1. Unio reftosus, kuf.x

2. Uniof fient:o sms R aff 



\title{
UNIO PHILLIPSII.
}

\author{
Plate V.-Fig. 1.
}

DESCRIPTION.

Shell subovate, with concentric furrows; anterior side smooth; disk with a single row of irregular tubercles in the centre, some of which are elongated and grooved; posterior side narrowed, with a wide furrow and a few small tubercles; umbonial slope straight, carinated and tuberculated; posterior slope concave, indistinctly tuberculated; ligament slope rectilinear, oblique; extremity direct, emarginate; basal margin swelling centrally, emarginate behind; umbo prominent, rather broad, flattened at the summit; beaks retuse; epidermis yellowish-brown, with indistinct filiform rays over the umbo; within white; cardinal teeth rather small, direct, double in each valve.

\section{OBSERVATIONS.}

This handsome species is allied to $\boldsymbol{U}$. quadrulus, RAF., but is very distinct, the young shell having broad smooth and retuse beaks, whilst the young of the quadrulus has the beaks narrowed, tuberculated, pointed and curved forwards. The specimen figured is from the Wabash, and is in the cabinet of $\mathrm{Mr}$. John Phillips, who called my attention to it as a distinct species, and I have dedicated to him a small tribute of respect for his talents and scientific zeal. 


\title{
UNIO METANEVRUS.
}

\author{
Plate V.-Fig. 2. \\ DESCRIPTION.
}

Shell suboval, thick, ventricose; anterior side tuberculated, except near the margin, which is smooth; disk with an oblique furrow; umbonial slope very prominent, broad and rounded, with numerous tubercles, some of which are very large; posterior slope wide, concave, or angular, with oblique slightly recurved series of rib-like tubercles; umbo slightly prominent; beaks retuse; ligament margin oblique, rounded at the extremity; posterior margin emarginate; epidermis yellowish-brown, with interrupted green rays; within white, much thickened anteriorly.

\section{SYNONYMES.}

U. metaxevra, Raf. Aun. gen. des Sc. Phys. vol. v. p. 39. Ferussac, Mag. de Zool.

U. No dosus, Barnes. Silliman's Journal, vol. vi. p. 124, pl. vi. fig. 7 .

Cab. A. N. S. No. 1754.

OBSERVATIONS.

A common species in the western and southern rivers, easily recognised, when in perfection, by its swelling umbonial slope: very old specimens much resemble $\boldsymbol{U}$. stapes, Les, but are much larger. 

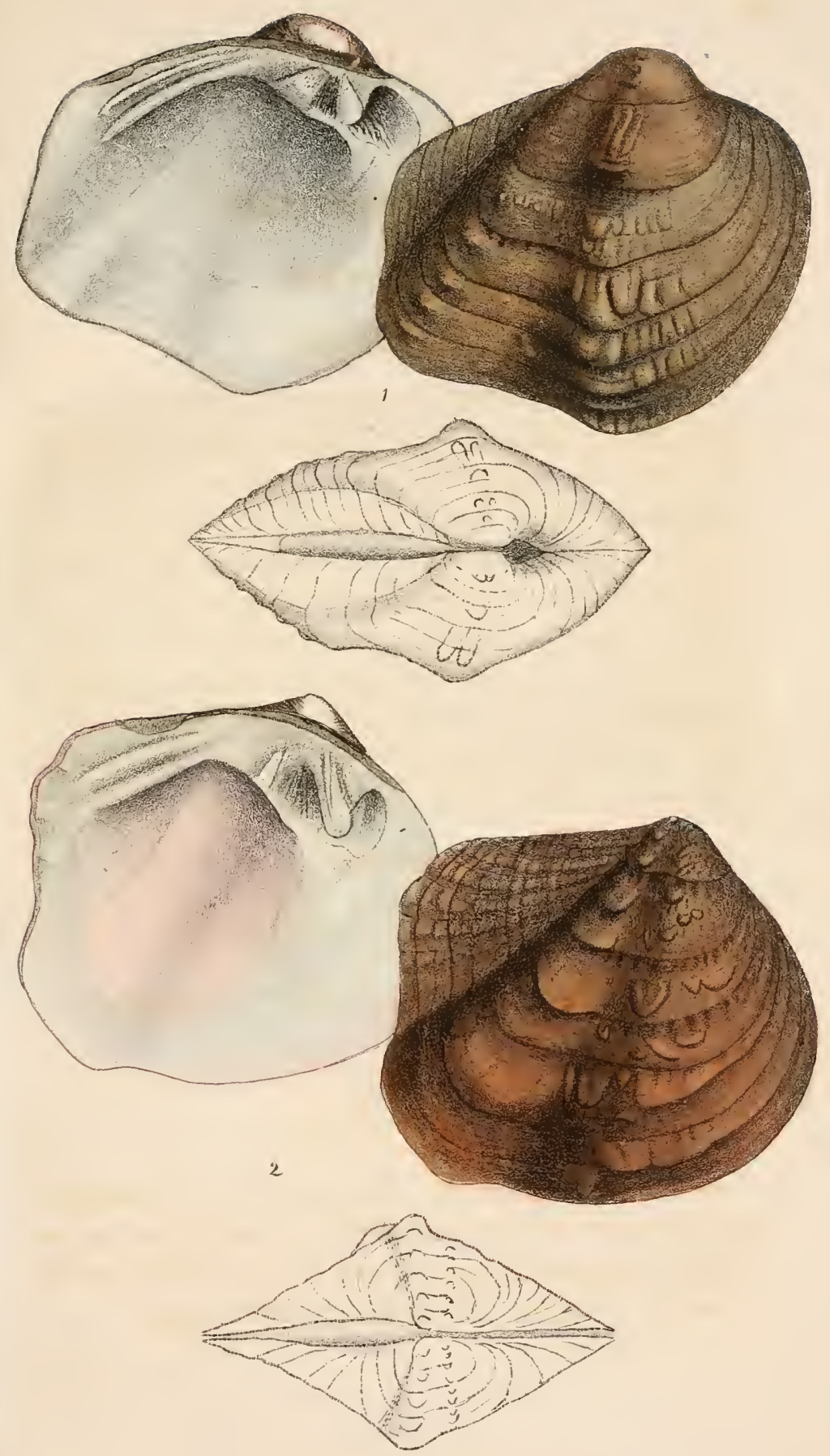

1. Inio Pfillipsii, con. 2. Unio Metaneurus, Raf. 



\title{
UNIO MORTONI.
}

\author{
Plate VI.-Fig. 1.
}

DESCRIPTION.

Shell suborbicular, not thick, ventricose; disk flattened, or slightly furrowed from beaks to base, covered with irregular tubercles; anterior margin subtruncated; posterior margin straight, direct; ligament margin subarcuate, oblique, forming an angle with the posterior margin; umbo with an oblique furrow, prominent; beaks rather retuse, decorticated; umbonial slope angular, slightly arcuate; posterior slope flattened; epidermis yellowish brown, with fine crowded wrinkles; within white; anterior margin not thickened; cardinal teeth compressed, very prominent, oblique.

Cab. A. N. S. No. 1874.

\section{OBSERVATIONS.}

This pretty species is common in Bayou Teche, Louisiana; but I have seen it from no other locality; it approaches nearest to the quadrulus, $\mathbf{R}_{\mathrm{AF}}$., but differs greatly in size, convexity, and want of a distinct furrow from beak to base. It is dedicated to my friend Dr. S. G. Morton, whose exertions have furnished a splendid collection of American and foreign fresh water shells to the Academy of Natural Sciences. 


\title{
UNIO FRAGOSUS.
}

\author{
Plate VI.-Fig. 2.
}

\section{DESCRIPTION.}

Shell suborbicular, ventricose, with an indistinct narrow furrow, and two approximate series of very prominent irregular tubercles, anterior ones largest; umbonial slope angular; posterior slope slightly concave, with a few narrow rib-like tubercles, more prominent near the margin; posterior margin direct, slightly emarginate; ligament slope straight, slightly oblique; umbo narrow, prominent; beaks much incurved, pointed, tuberculated; epidermis brown, with two or three broad, widely interrupted green rays.

\section{OBSERVATIONS.}

This fine species approaches quadrulus, $\mathbf{R}_{\mathrm{AF}}$., but is much more ventricose, has more prominent tubercles, and is very distinct. I am indebted to Dr. Blanding for the splendid specimen represented by the figure; it is from the Scioto river, Ohio. 


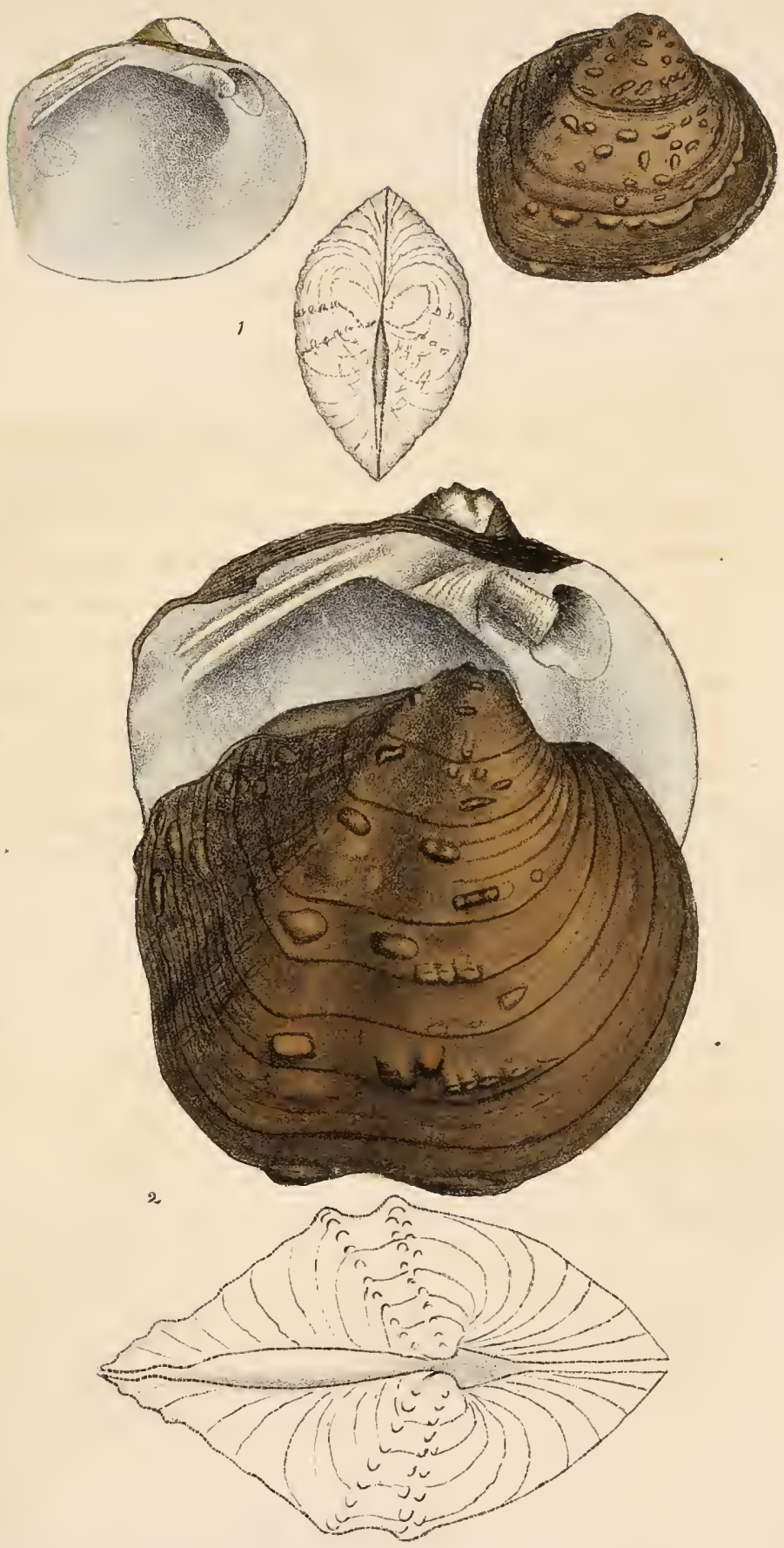

1. Unio Mortoui, Con. 2. Unio fraggsus, Conrad. 



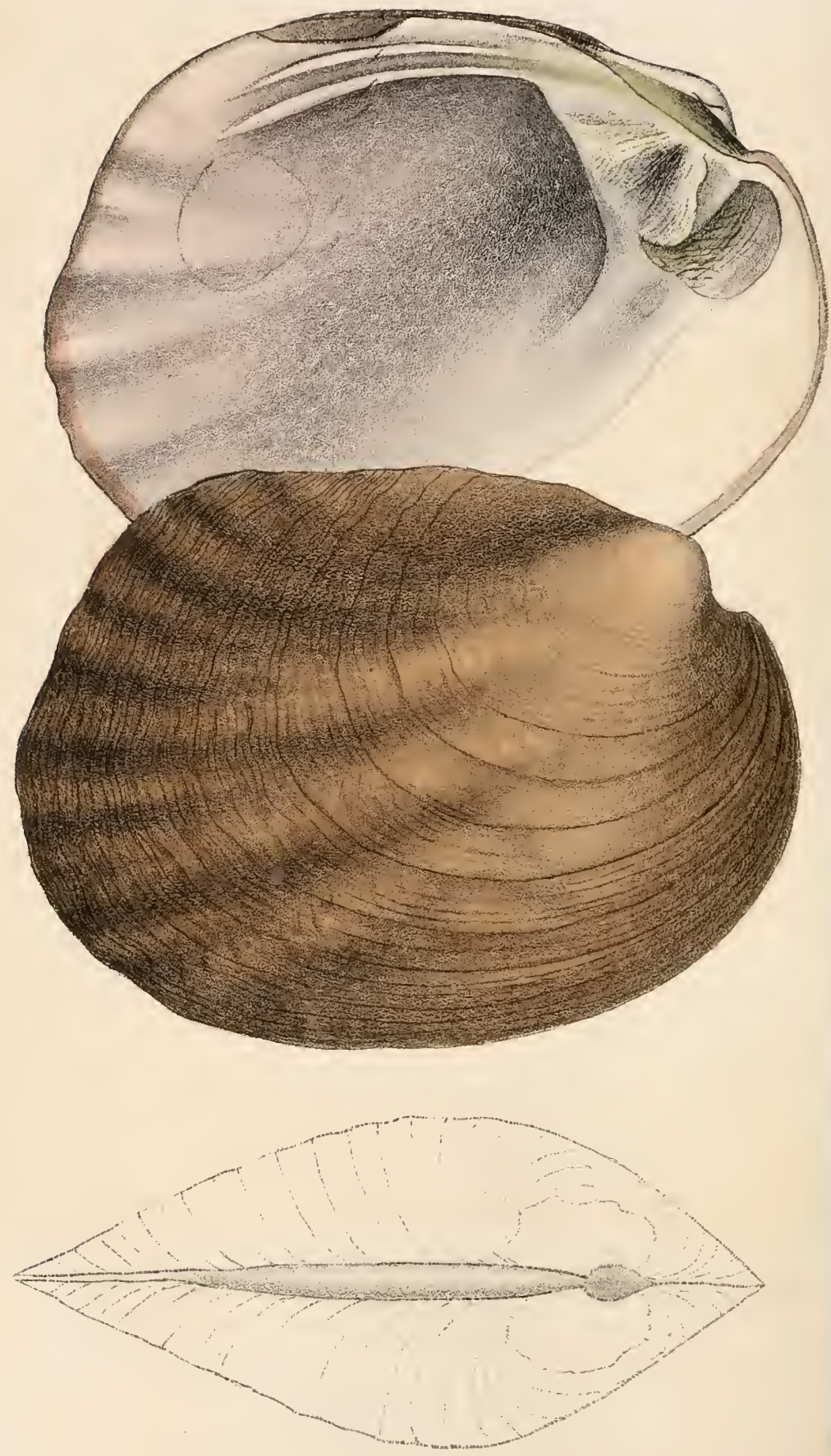

Ulio rinsfulus, Rnf. 


\section{UNIO COSTATUS.}

\section{Plate VII.}

\section{DESCRIPTION.}

Shell suboval, slightly ventricose anteriorly; disk with profound oblique undulations, numerous and recurved behind the umbonial slope; umbo narrow, slightly prominent, oblique, nearly terminal; ligament margin elevated, nearly straight; epidermis yellowish brown, sometimes blackish brown, much wrinkled posteriorly; within white, iridescent posteriorly, waved on the margin; cardinal teeth very thick.

\section{SYNONYMES.}

U. costatus, Raf. Ann. gen. des Sc. Phys. vol. v. p. 49. pl. lxxxii. fig. 13, 14. Poulson's trans. p. 57. Say, Amer. Conch. No. 6. Ferus. Mag. de Zool.

U. undulatus, Barnes. Silliman's Journ. vol. vi. p. 121, pl. 2.

OBSERVATIONS.

This shell very nearly approaches $U$. plicatus, $\mathrm{S}_{\mathrm{AY}}$, and some varieties can scarcely be distinguished from it. It has, in general, more undulations, a much less prominent umbo, is less ventricose, and has often a yellowish epidermis, which is not the case with the plicatus. Not uncommon in the western waters, and in the Alabama river; very large and fine in the rivers of Tennessee. 
This species in some of its varieties so nearly resembles $\boldsymbol{U}$. heros, of $\mathrm{S}_{\mathrm{AY}}$, when the latter is old and eroded on the umbones, that $\mathrm{Mr}$. $\mathrm{S}_{\mathrm{AY}}$ at one time considered them identical; the young shell of the heros, however, was found to be so entirely dissimilar to the young of the costatus, that the specific difference was obvious to the most careless observer, and Mr. $\mathrm{S}_{\mathrm{AY}}$ in his synonymy retains his species. This circumstance should induce those naturalists who live in favourable situations to study the young of every species, for as Mr. Lea has justly observed, they are the most certain guides to specific distinctions; when the umbones and beaks are perfect, most species will exhibit very nearly the prominent characters of the very young shells, and hence the necessity of procuring cabinet specimens of the most perfect description, if we would effectually trace the species and make ourselves acquainted with their affinities. 



\title{
UNIO PARVUS.
}

\author{
Plate IX. - Fig. 1.
}

DESCRIPTION.

Shell oblong or elliptical, with prominent concentric lines, and slightly contracted from beak to base; inflated posteriorly and the basal margin dilated and rather abruptly ascending to the extremity, which is narrow, obtuse, and much above the line of the base; umbo when not decorticated, profoundly sulcated; umbonial slope undefined; posterior slope with a submarginal, slightly prominent line; ligament margin not oblique; posterior margin obliquely truncated above; within white; cardinal teeth very erect.

\section{SYNONYMES.}

U. Parves, Barnes. Silliman's Journal, vol. vi. p. 174. Cab. A. N. S. No. 1872.

OBSERVATIONS.

A small species, without any prominent character, yet very distinct. It approaches nearest to $U$. lienosus, nob. but that species is always more or less radiated and generally pink or purple in the interior; the parvus is white within and rarely rayed. Inhabits western rivers generally from Bayou Teche in Louisiana to Fox river in the North Western Territory.

An elegant specimen from the Scioto river is dark olive-green and distinctly rayed; and the acutely angulated ridges on the beaks are very perfect. 

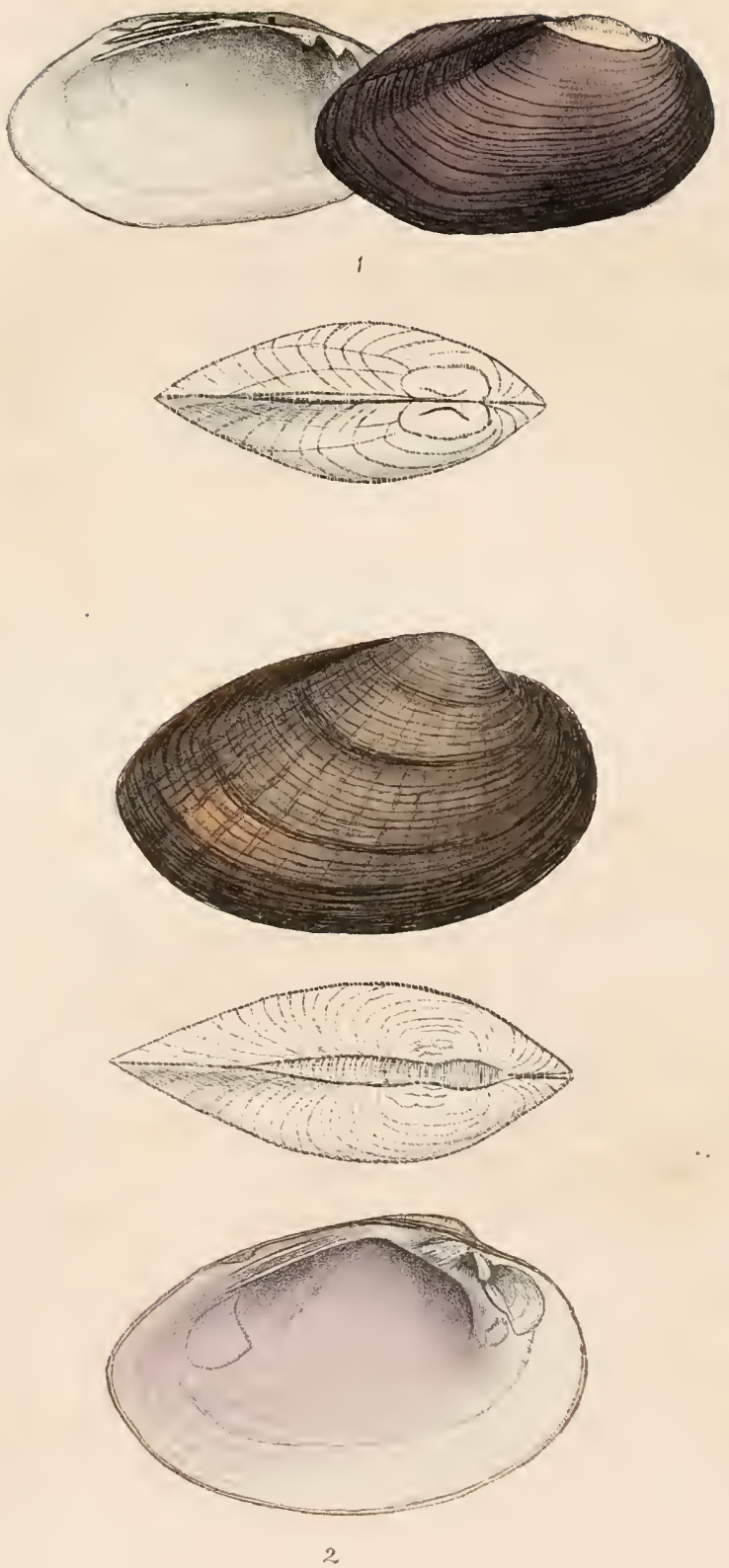

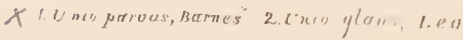





\section{UNIO GLANS.}

Plate IX.-Fig. 2.

DESCRIPTION.

Shell ovate-elliptical, thickened anteriorly; surface with numerous concentric lines; anterior side short; posterior side subcuneiform; umbo slightly prominent; beaks undulated; umbonial slope undefined; epidermis generally dark brown, sometimes rayed; within dark purple, except on the anterior margin; cardinal teeth prominent, direct.

\section{SYNONYMES.}

U. glans, Lea. 'Trans. Amer. Philos. Soc. new series, vol. iv. pl. viii. fig. 12.

Cab. A. N. S. No. 1168.

\section{OBSERVATIONS.}

This does not appear to be an abundant species, yet it is occasionally found in the waters of Ohio, Tennessee and Alabama. In the latter state I met with it only in the tributaries of the Tennessee river. The purple nacre and white anterior margin will always distinguish this species from any other, which resembles it in form. Another peculiarity is the posterior tooth of the left valve pointing to the posterior extremity, which causes the teeth to diverge greatly. It most resembles $\boldsymbol{U}$. lienosus, nob. and $\boldsymbol{U}$. parvus, Barnes. The figure represents the largest and best specimen $I$ have seen, and the only one that is distinctly rayed; it is from the Harpeth river, Tennessee. 


\title{
UNIO SILIQUOIDEUS.
}

\author{
Peate X.-Fig. 1.
}

DESCRIPTION.

Shell ovate-oblong or elliptical, ventricose, moderately thick; surface glabrous, olive-yellow, with numerous green rays varying much in size; anterior side not very short, margin regularly rounded; ligament margin straight, not declining; posterior extremity angulated; umbonial slope undefined; beaks with flexuous undulations; within bluish-white; cardinal teeth oblique, lateral teeth slightly decurved posteriorly.

\section{SYNONYMES.}

U. sıliquoideus, Barnes. Silliman's Journ. vol. vi. p. 269.

U. Inflatus, 16 . p. 267.

Cab. A. N. S. No. 1055.

\section{OBSERVATIONS.}

The species which most resembles this appears to be the radiatus, which for comparison we figure upon the same plate. Young specimens differ constantly from the radiatus in having a straw-coloured highly polished epidermis, and much undulated beaks; are more inflated, have the anterior side longer and the margin more regularly rounded. The sexual varieties are far more strongly marked, some specimens having almost the form of $\boldsymbol{U}$. cariosus, whilst the radiatus offers comparatively slight differences of outline. Old shells become thick and much inflated, and 
resemble in form the $\boldsymbol{U}$. teres, $\mathrm{R}_{\mathrm{AF}}$. common in the western rivers. I did not observe it in Alabama.

$\mathrm{Mr}$. Say, in his synonymy of the western species, has given the siliquoideus as a synonyme of $\boldsymbol{U}$. cariosus, considering it a mere variety of that species, and more strangely merges the radiatus in the same. We have seen abundance of both the latter and cariosus, in the Schuylkill and Delaware, but never any varieties of either which could for one moment have led us to confound the two species. Mr. Lea informs us that a specimen of the siliquoideus in the Garden of Plants at Paris, is labelled lutcola of Lamarck; this name we should have adopted if Ferussac had not referred Lamarck's specimen of luteola to cariosus, of $\mathrm{S}_{\mathrm{AY}}$, which we presume to be correct, as that distinguished naturalist is well acquainted with those species which are common in the United States.

In Bayou Teche there occurs a beautiful species allied to this if it be not a variety; it is distinguished by a darker epidermis, with distant and dark green rays of nearly uniform size. We have not seen many specimens, but a figure of it will be given when its characters shall be determined and its affinity with the siliquoideus clearly ascertained. 


\title{
UNIO RADIATUS.
}

\author{
Plate X.-Fig. 2.
}

DESCRIPTION.

Shell oblong-ovate, thin, slightly compressed on the anterior side; surface with fine wrinkled lines and distinct furrows; olive, with numerous green rays, varying in size; anterior side short and narrowed; margin abruptly rounded; posterior side dilated; ligament margin elevated, slightly curved; anterior basal margin slightly contracted; umbonial slope undefined; posterior extremity subtruncated; within yellowish or salmon coloured, and thickened anteriorly; bluish and highly iridescent posteriorly.

\section{SYNONYMES.}

U. radiata, Lam. An. sans vert. vol. vi. p. 73 .

Barnes. Silliman's Journ. vol. vi. p. 265.

Mya radiata, Spengl. Gmel.

U. virginiana, Lam. An. sans. vert. vol. vi. p. 79 .

U. oblongata, Wood. Suppl. Index. Test.

Cab. A. N. S. No. 1116.

\section{OBSERVATIONS.}

A common species in the tide waters of the middle states, and very abundant in those of Virginia, but it has not been found in any of the tributaries of the Mississippi, except the Ouisconsin river, where, according to Mr. Barnes, it was obtained by Mr. Schoolcraft. This naturalist remarks that it inhabits Saratoga lake. 

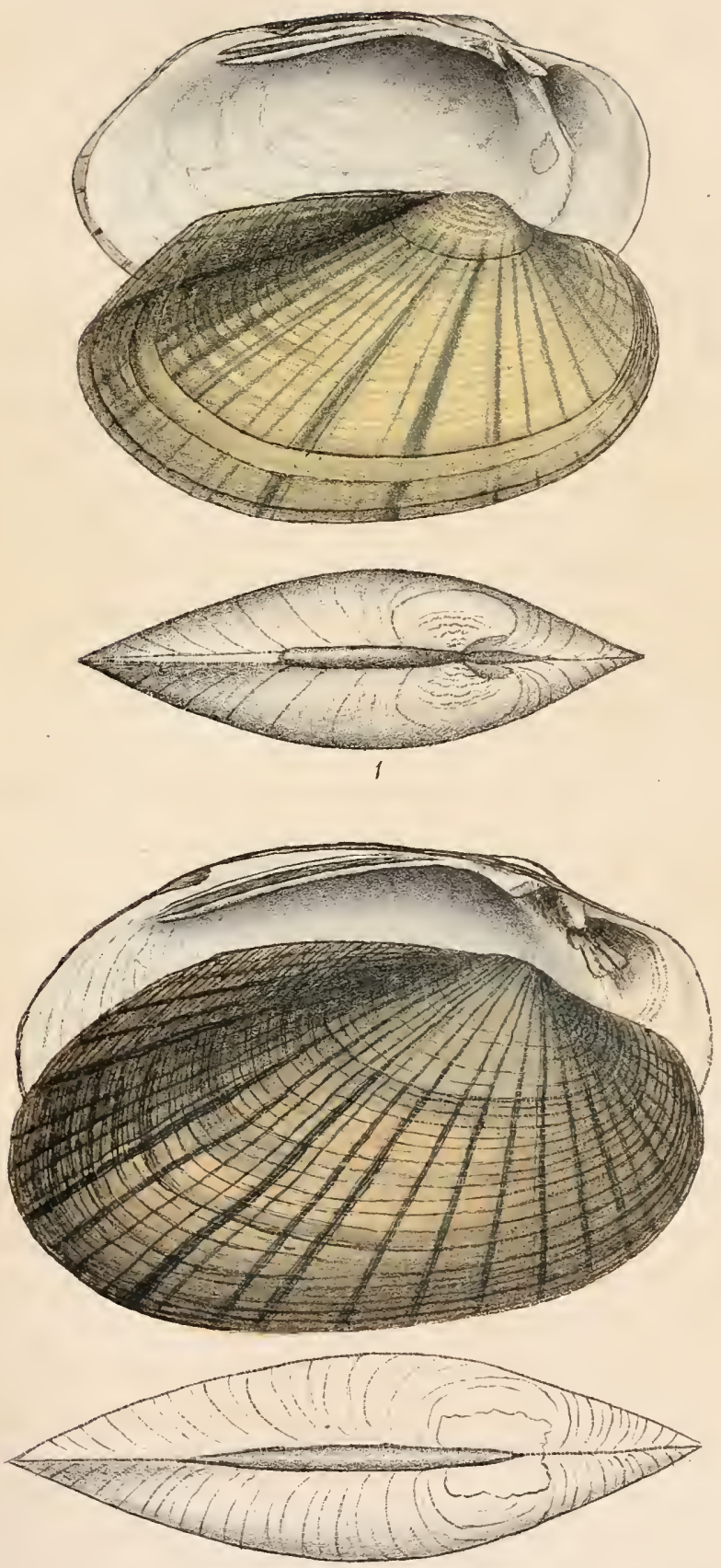

1. Lnio siliquoideus, Barnes. 2. Enio radiatus," Lamatek. 



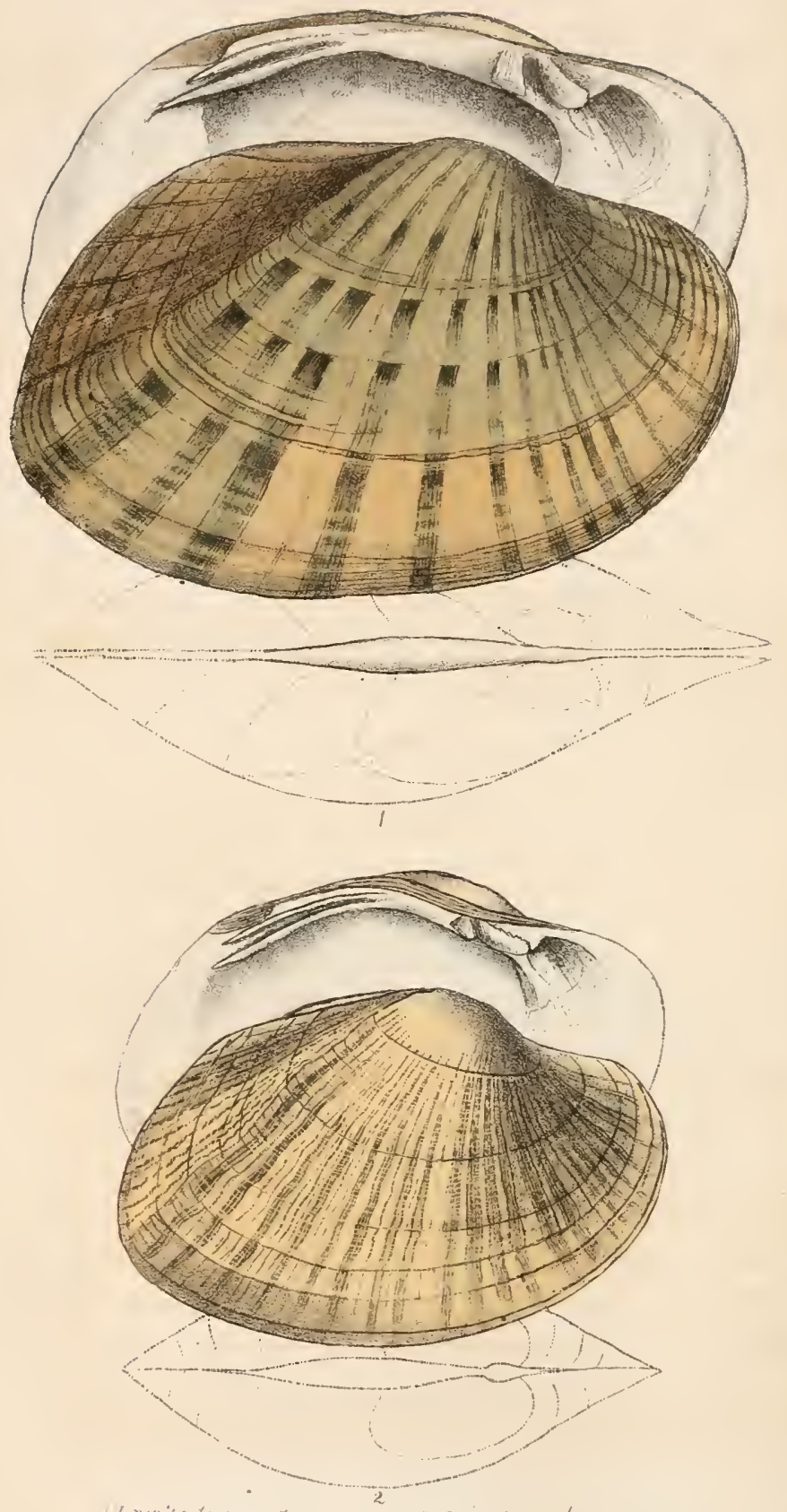

Inio pecteressus, c'

2. Enis firsecoíns. $k$ af 


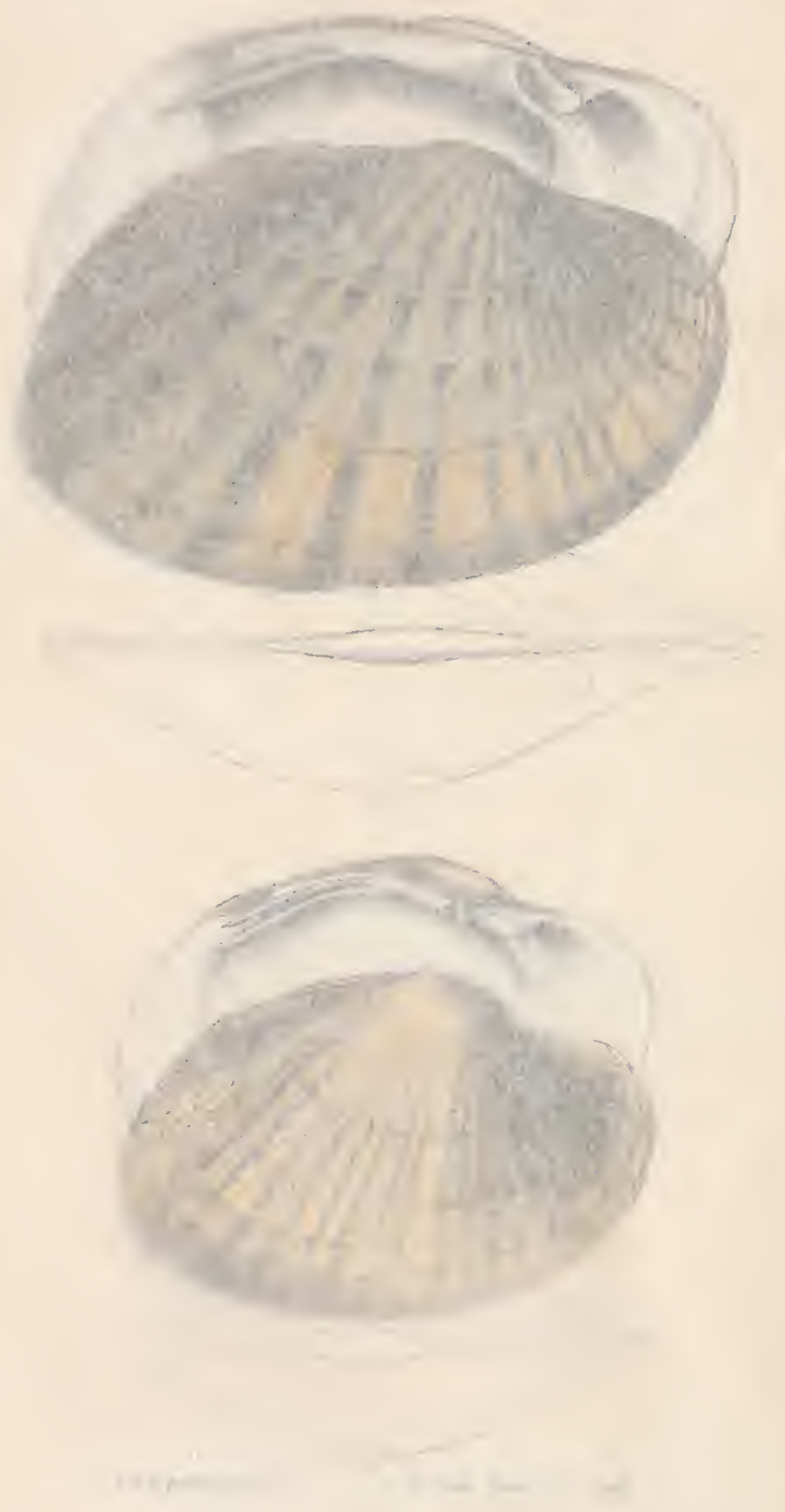




\title{
UNIO PECTOROSUS.
}

\author{
Plate XI.-Fig. 1.
}

DESCRIPTION.

Shell elliptical, inflated, moderately thick, yellowish or olive, with unequal green rays, the larger rays having distant dark spots; anterior side compressed, extremity acutely rounded; ligament margin parallel with the base; umbonial slope angular; umbo broad, prominent, summit obtusely rounded; beaks distant from the anterior extremity; within white, with a wide greenish margin; cardinal teeth thick, prominent, direct; cardinal plate dilated.

\section{SYNONYME.}

U. pectorosus, Nob. New fresh water shells, p. 37. pl. vi.fig. 1 . May, 1834.

U. Perdix, Lea. Trans. Amer, Philos. Soc. new series, vol. v. p. 72. pl. xi. fig. 31. Sept. 1834.

Cab. A. N. S. No. 2102.

\section{OBSERVATIONS.}

This shell has so nearly the outline of $\boldsymbol{U}$. fasciolus, that I have figured both on the same plate for comparison. It differs from that species in the rays, dilated cardinal plate, \&c. It is allied to $U$. ovatus, Say, but is much more elongated. The specimen represented has double cardinal teeth in each valve, but the character is not permanent. It is in the splendid collection of Mr. Poulson, and was found in the Harpeth river, Tennessee. I obtained a few specimens 
on the bank of Elk river, Alabama, in which the epidermis was dark and the rays obscure. Mr. Lea compares it with the crassus, Say, but we cannot find any point of resemblance.

\title{
UNIO FASCIOLUS.
}

\author{
Plate XI.-Fig. 2.
}

DESCRIPTION.

Male. Shell elliptical, inflated, yellowish, with numerous unequal flexuous green rays; anterior margin regularly, not obtusely rounded; posterior extremity angulated; ligament margin slightly declining; umbo wide, prominent; beaks retuse, distant from the anterior extremity; umbonial slope obtusely rounded; within white; cardinal teeth prominent, diverging; margin horn-coloured, shewing the exterior rays.

Female. Short ovate; posterior side dilated; umbo narrower and more oblique; ligament margin elevated.

\section{SYNONYMES}

U. Fasciolus. Raf. An. gen des Phys. Sec. vol. 5. p. Poulson's trans. p. 28. Say. Amer. Conch. No. 6.

U. multiradiatus, Lea. Trans. Amer. Philos. Soc. new series. vol. 3. p. 48. pl. ix. fig. 15 .

Cab. A. N. S. No. 1429.

OBSERVATIONS.

Distinguished by its numerous unequal green undulated rays; without these the female might be 



$$
0
$$

엉 
mistaken for $\boldsymbol{U}$. cariosus. Old shells are very thick and ponderous, and Mr. Poulson has a fine specimen of this description. Had the Baron de Ferussac seen this, we think he would not for a moment have deemed it a variety of $\boldsymbol{U}$. subovatus. Mr. Phillips has two fine specimens, male and female; the former is represented.

\section{UNIO CONGAR EUS.}

Plate XiI.-Fig. 1.

DESCRIPTION.

Shell elliptico-rhomboidal, thin, somewhat flattened at the sides; epidermis olive or reddish-brown, with numerous green rays, sometimes obsolete; umbones flattened, broad; summits obtusely rounded, slightly prominent; umbonial slope profoundly angulated; ligament slope slightly oblique; posterior slope much depressed, with oblique, irregular, undulated lines; within white, highly iridescent; cardinal teeth oblique; lateral teeth elongated, slightitly curved.

\section{SYNONYME.}

U. cosgareus, Lea. Trans. Amer. Philos. Soc. new series, vol. 4. p. 72. pl. vi. fig. 4. Cab.A. N. S. No. 2101.

OBSERVATIONS.

Inhabits the eastern waters of South Carolina. I found it also at Augusta, Georgia, in great numbers. 
It certainly approaches $U$. niger, Raf.; the young of the latter resembling it so much, as to lead to the inference that they may be varieties of one species, occasioned by difference of locality. Specimens from Augusta resemble the niger more than those from the Congaree river; and in Flint river, Georgia, is a variety of the latter, differing only from the congarceus in being rather larger and more ponderous.

\title{
UNIO MASONI.
}

\author{
PLATE XII.-Fig. 2.
}

DESCRIPTION.

Shell suboval, thin; umbones broad, inflated, disks slightly flattened near the umbonial slope; beaks distant from the anterior margin; ligament margin elevated; umbonial slope angulated; epidermis olivaceous, polished, wrinkled inferiorly; summits decorticated; within white, cardinal teeth oblique, rather thick.

\section{SYNONYME.}

U. Masoxi, Nob. New fresh water shells, p. 34. pl. 5. fig. 2. Cab. A. N. S. No. 2100.

\section{OBSERVATIONS.}

Inhabits Savannah river, at Augusta. When the description was originally published, I had seen only 


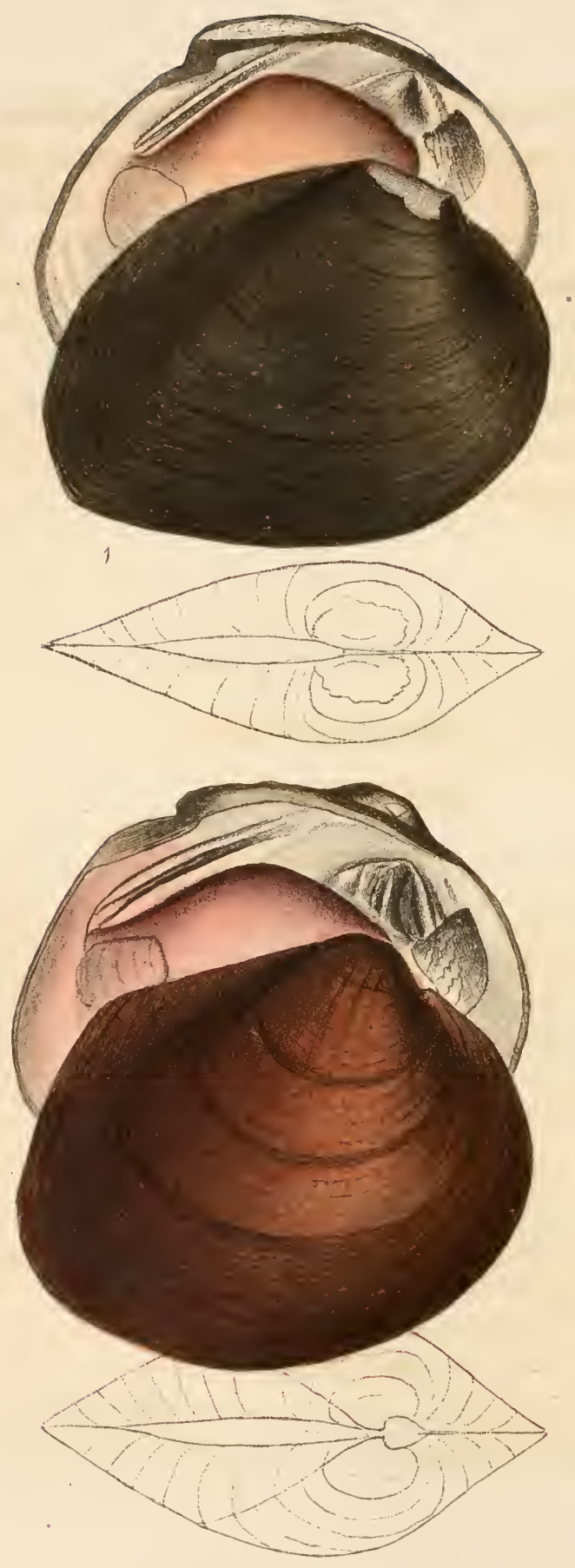

I"nio cueneneus Hildrrifh. U catillus, C. Jun. 1.50 
the young shell, but subsequently, in examining a number of specimens of $\boldsymbol{U}$. congaraus from the same locality, an adult specimen was discovered, which has served for the figure and description. It is in $\mathrm{Mr}$. Phillips's cabinet. The outline of the young shell is represented for comparison with that of $\boldsymbol{U}$. congaraus. Mr. Poulson's cabinet.

It is dedicated to Mr. William Mason, whose discoveries have much advanced our knowledge of American conchology.

\section{UNIO COCCINEUS.}

\section{Plate XIII.-Fig. 1.}

\section{DESCRIPTION.}

Shell oblique, subtriangular, compressed, slightly waved; epidermis blackish-brown, with crowded wrinkles; anterior side very short; posterior side subcuneiform, much compressed, extremity truncated; umbo slightly flattened; basal margin not much arcuated posteriorly; posterior margin slightly sinuous, oblique, rounded above; umbonial slope abruptly rounded; summits prominent, eroded; within salmon colour, rarely white; cardinal teeth double in each valve, direct.

\section{SYNONYME.}

U. coccineus, Hildreth.

Cab. A. N. S. No. 2104. 
'This shell, in having a slightly undulated disk, approaches the myliloides, Raf., but is very distinct. It is well known in the collections by the name we have adopted, but we are informed that Dr. Hildreth has not published his description of it. I have figured a fine specimen from Mr. Hyde's cabinet. This naturalist observes that the species inhabits Mahoning river, near Pittsburg, and that of the very many specimens he has received, none has perfect beaks.

\section{UNIO CATILLUS.}

\section{PLATE XIII.-FIG. 2.}

DESCRIPTION.

Shell oval orbicular, slightly oblique, moderately thick, convex, dark chestnut-brown, with crowded wrinkles; anterior margin obtusely rounded or subtruncated; posterior margin rectilinear, nearly direct, extremity rounded; umbonial slope rounded; umbones inflated, narrow, prominent; ligament margin rectilinear, oblique, angular posteriorly; summits slightly flattened; beaks much incurved, pointed, slightly tuberculated; lunule short ovate; within rosaceous; cardinal tecth thick, direct, profoundly sulcated; lateral tooth of the left valve very thick, that of the right valve compressed, and rising from a very broad plate or base projecting on either side; cardinal plate profoundly dilated.

C'ab. .A. N. S. No. 2103. 
This species has been sent from the west, under the name of coccincus, but is so very distinct that $I$ should not otherwise have compared it with that species. It approaches nearest to the politus of Say, and obliquus, Lam., but the peculiarity of the teeth and greatly dilated cardinal plate, as well as many other characters, forbid a union with either. Mr. Hyde informs me that a great number of specimens in his possession, from the Scioto river, shew the interior to be generally of a rose colour or purple, occasionally nearly white, and rarely salmon. Of the latter Mr. Hyde possesses a specimen more beautifully coloured than any Unio I have seen-it will be figured in a future number. The figure is from a specimen in the cabinet of Mr. Phillips.

\section{UNIO PRODUCTUS.}

Plate XIV.-Fig. 1.

DESCRIPTION.

Shell narrow-elliptical, produced, moderately thick, slightly ventricose, somewhat contracted near the middle; anterior side short, dilated, margin obtusely rounded; basal margin sinuous; posterior side rostrated; extremity rounded, mucl above the line of the base; ligament margin parallel with the line of the base; umbonial slope obtusely carinated; umbo decorticated, not elevated above the dorsal line; within 
purplish; cardinal teeth thick, direct; lateral teeth thick.

OBSERVATIONS.

On a passing glance this shell would certainly be mistaken for $\boldsymbol{U}$. nasutus, but the thickness of the shell, the dilated anterior side, and thick, direct, lateral teeth, will sufficiently distinguish it. The disk posteriorly has several small plicæ or undulations similar to those of $\boldsymbol{U}$. grayamus, Lea, but as only one specimen can be examined this character may prove inconstant.

In the cabinet of Mr. Phillips. I found it on the shore of Savannah river, at Augusta, and supposed it to be a variety of nasutus, but comparing it with that species from South Carolina and Florida, it was found to differ materially, and to form a link between it and the rectus.

\title{
UNIO LANCEOLATUS.
}

\author{
Plate XIV.Fig. 2.
}

DESCRIPTION.

Shell narrow-elliptical, thin, ventricose, yellowish, smooth and polished; disks slightly flattened; anterior side somewhat compressed, not very short, margin regularly rounded; umbonial slope regularly rounded, inflated; posterior side produced, extremity 

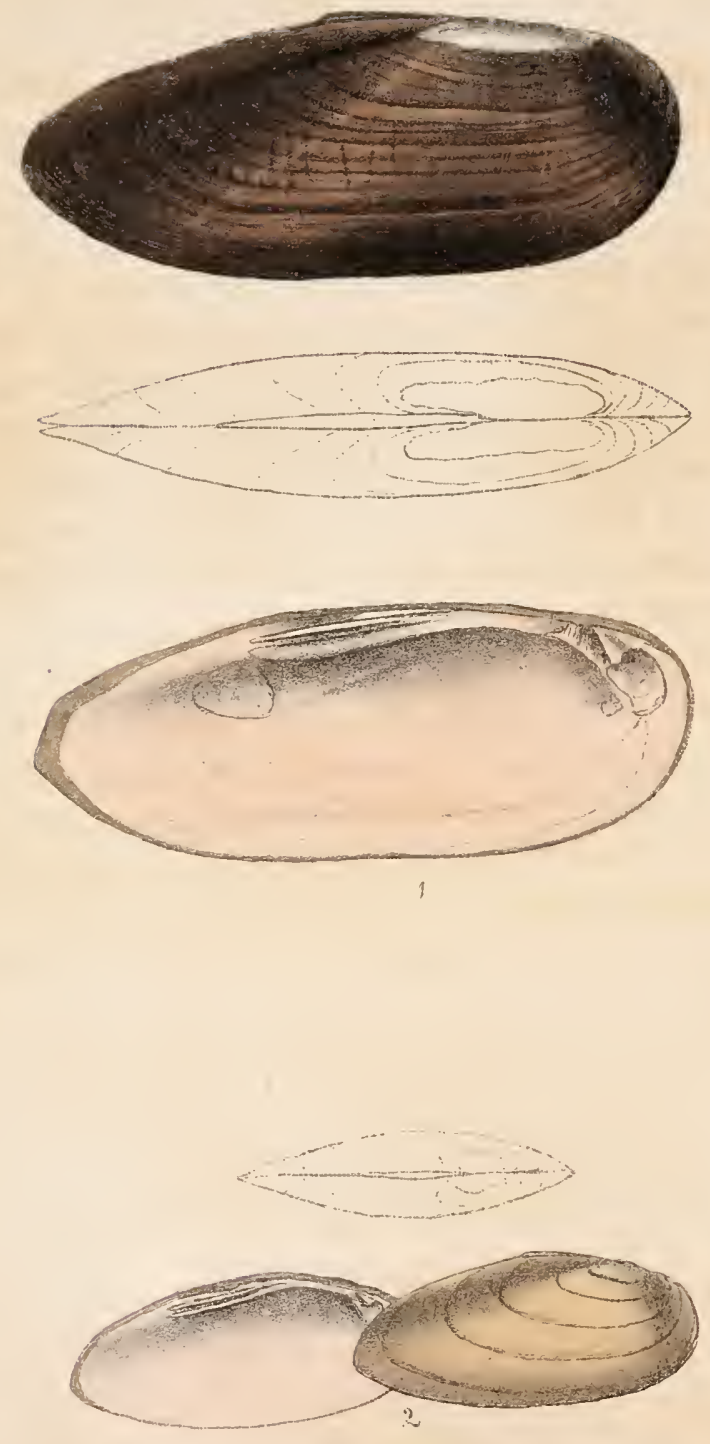

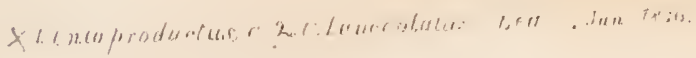






angulated; beaks not prominent; ligament margin short, elevated; within pale salmon colour; lateral teeth slightly recurved.

SYNONYME.

U. lanceolatus, Lea. Trans. Amer. Philos. Soc., new series, vol. iii. pl. 3. fig. 2.

Cab. A. N. S. No. 1105.

OBSERVATIONS.

Inhabits Tar river, N. C., Mr. Lea. Mr. Hyde has received specimens from the Rappahannoc at Fredericksburg, Va. It approaches nearest in outline to $\boldsymbol{U}$. productus and nasutus, but cannot be easily confounded with either.

\section{UNIO RECTUS.}

Plate XV.

DESCRIPTION.

Shell profoundly elongated, thick; anterior side short; posterior side rostrated, cuneiform; extremity angular, compressed; umbo inflated, but not prominent, obtusely rounded; disks slightly contracted in the middle; ligament margin nearly rectilinear; epidermis dark green or olive-brown, smooth, frequently with broad green rays; within pink in the middle; cardinal teeth small, direct, double in each valve.

SYNONYMES.

U. Rectus, Lam. An. sans vert. vol. vi. p. 74.

$\mathrm{E}$ 
U. Latissima, Raf. An.gen. des Sc. Phys. vol. 5. p. 31. Poulson's trans. p. 25.

U. prefongus, Barnes. Silliman's Jour. vol. vi. p. 261.

Cab. A. N. S. No. 1112.

\section{OBSERVATIONS.}

This shell resembles in outline $U$. nasutus, Say, $U$. lanceolatus, Lea, and U.tcres, Raf. With the latter it has most affinity. It is a common western species, found as far north as the Ouisconsin, and inhabits the Alabama river near Claiborne. The figure was taken from a fine male specimen in Mr. Poulson's cabinet.

\section{UNIO CRASSUS.}

\section{Plate XVI.}

\section{DESCRIPTION.}

Male. Shell ovate, thick, yellowish, with brown rays, obsolete inferiorly; umbo broad, flattened; beaks obtuse, nearly terminal; umbonial slope angulated; posterior side cuneiform; posterior dorsal margin arcuate; basal margin dilated behind the middle; posterior extremity angular; within salmon colour or white, with a horn-coloured margin; cardinal teeth direct, thick, very prominent, subtrifid.

Fcmale. Shell oval quadrate, ventricose, posterior side dilated; posterior margin widely truncated, direct; umbo oblique and terminal. 


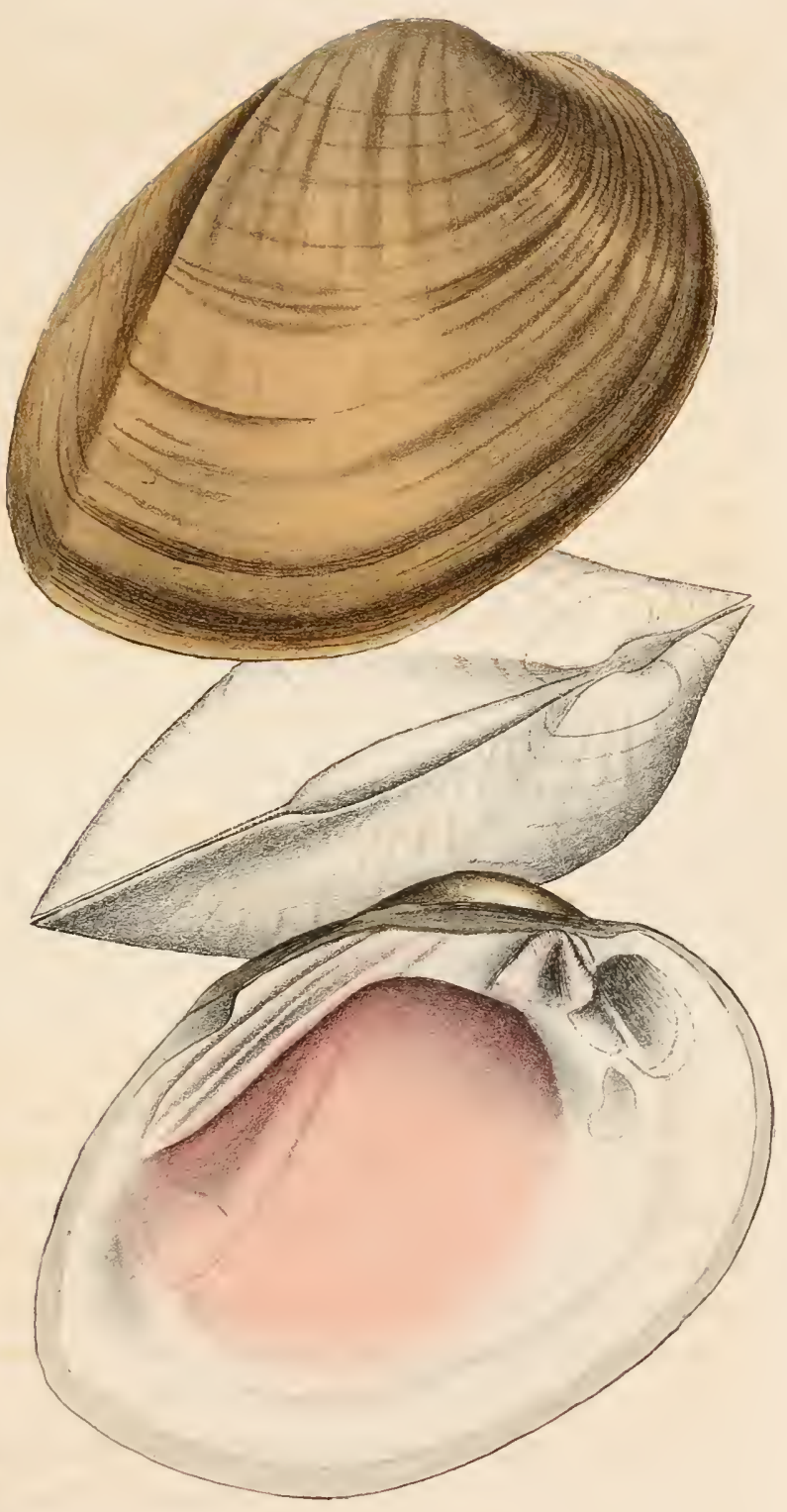

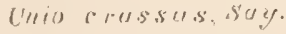



U. crassus, Say. Nich. Enc. (Amer. ed.) art. Conch. pl. i. fig. 8. old male.

U. crassidens, var. c. Lam. An. sans vert. vol. vi. p. 71 .

U. ligamentina, ib. p. 72.

U. ellipticus, Bames. Silliman's Jour. vol. vi. p. 259. male.

U. suborbiculatus, Hildreth. Silliman's Jour. vol. xiv. female.

U. abruptus, Say. Amer. Conch. pl. 17, female, var. A. male.

U. CycLps, Raf. Contin. of Monog. p. 2, female.

Cab. A. N. S. No. 358.

\section{OBSERVATIONS.}

Closely related to $\boldsymbol{U}$.fasciatus, Raf., but can be distinguished from that species by fewer and narrower rays, generally distinct only over the umbones; by a lighter coloured more polished epidermis; more prominent teeth, and the prevalence of a salmon coloured interior. Common in the rivers of Ohio, Indiana, and Illinois, but appears to be rare in the more southern states. I could not find it in the rivers of Alabama. The specimen figured was presented by Dr. Blanding.

\section{UNIO VIRIDIS.}

\section{Plate XVII.-Fig. 1.}

\section{DESCRIPTION.}

Shell elliptical or subovate, ventricose, thin; disks slightly flattened anteriorly, much inflated over the umbonial slope; lines of growth prominent; ligament margin elevated; posterior slope dilated; posterior 
extremity truncated, direct; epidermis with green rays, obsolete anteriorly, distinct and very unequal posteriorly; umbo slightly prominent; beaks with angular furrows, pointed; within white, iridescent; cardinal teeth compressed, oblique, that of the left valve double or trifid; lateral teeth of the left valve imperfectly divided.

\section{SYNONYME.}

U. viridis, Raf. An. gen. des Sc. Phys. vol.v. p. 27. Poulson's trans. p. 19.

Cab. A. N. S. No. 2105.

\section{OBSERVATIONS.}

The first specimen of this species which came under my observation, was found in the Schuylkill river, near Philadelphia, by Mr. Hyde, who kindly offered me the use of it, as I supposed it to be undescribed. Comparing it, however, with a single valve from the Kentıcky river, in Mr. Poulson's cabinet, it proved to be of the same species with that specimen which was labelled viridis by Rafinesque. Mr. Hyde has received specimens from a small stream near Lancaster, and from the Juniata river. One from the latter locality has been selected for the figure and description. It is allied to $\boldsymbol{U}$. heterodon, but cannot be confounded with that species. 


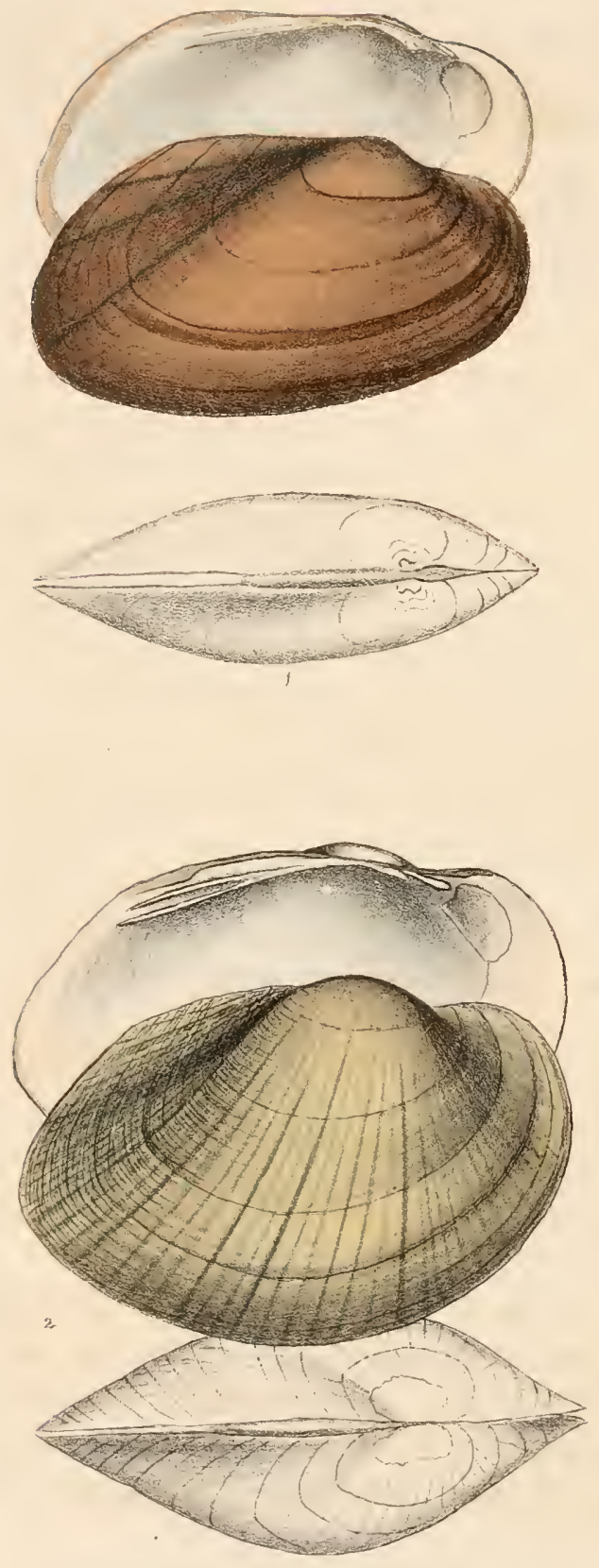

$\lambda$

1. Cnum whedis Raf. 2. Unin nchereens, say, 

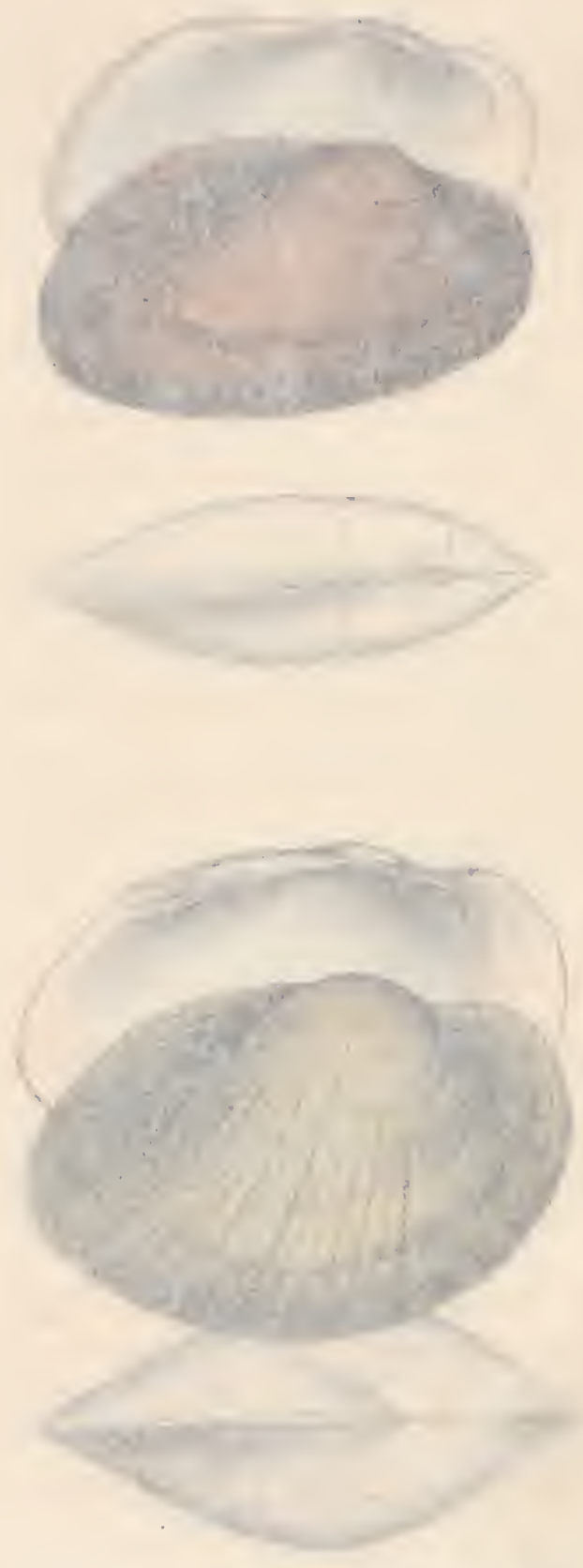


\title{
UNIO OCHRACEUS.
}

\author{
Plate XVII.-Fig. 2.
}

DESCRIPTION.

Shell elliptical, inflated, thin; epidermis smooth and polished, rugose posteriorly, yellowish, with narrow green unequal rays; anterior side narrowed, and the superior margin elevated and connate; ligament margin not oblique; umbo inflated; posterior extremity angular; umbonial slope angular; basal margin profoundly arcuate; within white, rarely pale rose or salmon; cardinal teeth very oblique, much compressed, bifid in the right valve; single or imperfectly divided in the left; lateral teeth arcuate.

Var. A. Reddish brown; rays obsolete or wanting; within rosaceous.

\section{SYNONYMES.}

U. ochraceus, Say. Nich. Enc. (Amer. ed.) art. Conch. pl. ii. fig. 8.

Symphynota ochracea, Lea. Trans. Amer. Philos. Soc., new series, vol. iii. p. 69.

Var. A. Mytilus fluviatilis, Gmel. Lister, tab. 157. fig. 12. Cab. A. N. S. No. 1063.

\section{OBSERVATIONS.}

Very common in the Schuylkill and Delaware rivers, and inhabits most tide waters north of Savannah river. Variety A. is very abundant in James river, Virginia, where I found vast numbers of shells brought ashore by seines used in the shad fishery in 
the month of March. So accurately does the above mentioned variety agree with Lister's figure and description, that I cannot doubt the identity. The species is, perhaps, most closely allied to $U$. cariosus, its common associate in the Delaware and Schuylkill. The specimen figured has a double cardinal tooth in each valve.

\section{UNIO NASUTUS.}

\section{Plate XVIII.-Fig. 1.}

DESCRIPTION.

Shell elongated, compressed, thin; disks slightly flattened; anterior side short; posterior side rostrated, tapering, angular at the extremity; umbo not prominent; beaks small, eroded; umbonial slope profoundly oblique, angulated; ligament margin rectilinear, elevated; posterior superior margin profoundly oblique and slightly concave; within bluish, iridescent, rarely purple or salmon; cardinal teeth compressed and oblique, double in each valve.

\section{SYNONYMES.}

U. nasurus, Suy. Nich. Enc. (Amer. ed.) art. Conch. pl. iv. fig. 1.

U. rostrata, I I alenc.

Lister, tab. 151. fig. 6.

Cab. A. N. S. No. 1123.

OBSERVATIONS.

A common species in the tide waters from Florida 


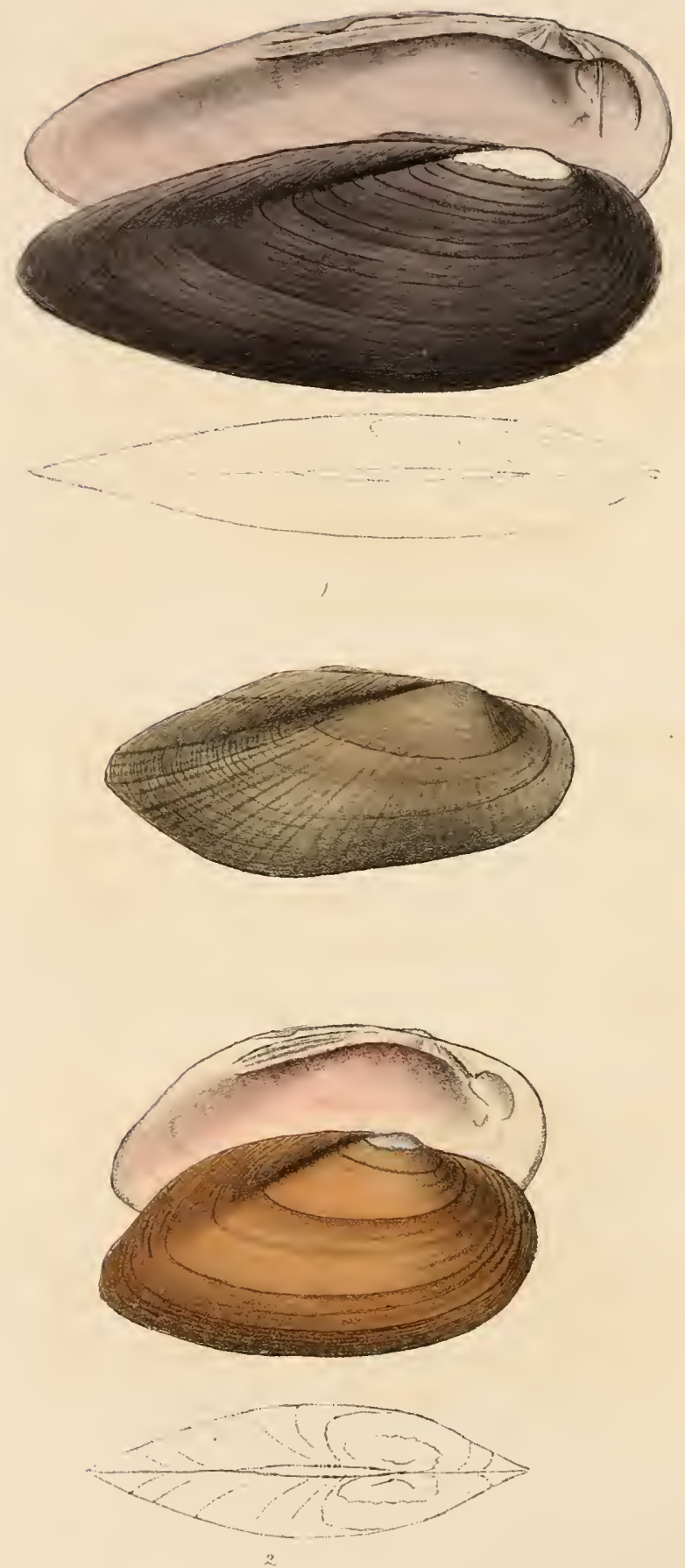
to the eastern states. I found it in great abundance in the Potomac river, near Washington, where the specimens are exceedingly elongated. The smaller specimen figured is a female variety from James river, Virginia, where they are generally ornamented with rays; the other figure represents a rare purple variety from Chester river, Maryland: it is in the cabinet of Mr. Phillips. In old shells the teeth are often thick and direct.

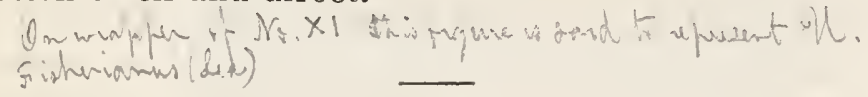

\section{UNIO ICTERINUS.}

\section{Plate XVIII.-Fig. 2.}

\section{DESCRIPTION.}

Shell elliptical, moderately thick; anterior margin regularly rounded; posterior margin descending obliquely, and subtruncated at the extremity; umbo not prominent; summit decorticated; umbonial slope very oblique, angulated; epidermis smooth and polished, olive yellow; within salmon coloured; cardinal tooth in the left valve trifid, in the right, single.

\section{SYNONYME.}

U. icterinus, Nob. New fresh water shells, p. 41. pl. vi. fig. 5 . Cab. A. N. S. No. 2106.

\section{OBSERVATIONS.}

I found the species in the Savannah river, at Augusta. It resembles $\boldsymbol{U}$. lanceolatus in epidermis and colour. Its proper place, we think, is between nasulus and declivis, Say. 


\title{
UNIO CARIOSUS.
}

\author{
Plate Xix.
}

\section{DESCRIPTION.}

Shell subovate, ventricose, thick anteriorly; epidermis yellowish or straw coloured, very smooth and polished, with a few narrow dark green rays posteriorly, more numerous on the posterior slope; umbo prominent, decorticated; umbonial slope angulated; ligament margin elevated; ligament prominent; basal margin swelling posteriorly; witlin white; cardinal teeth double in each valve, prominent, oblique.

\section{SYNONYMES.}

U. cariosus, Say. Nich. Enc. (Amer. ed.) art. Conch. pl. iii. fig. 2. female.

U. luteola, Lam. An. sans vert. vol. vi. p. 79.

U. ovatus, Valenc.

Cab. A. N. S. No. 1022.

OBSERVATIONS.

This is one of the most abundant species in the tide waters of the middle states, but I found it comparatively rare in the Potomac and James rivers. In varieties of form it much resembles $\boldsymbol{U}$. crassus, and both male and female are represented, in order to convey a clear idea of sexual differences, which are so striking in a large proportion of the species. It is very often destitute of rays, and I have seen only one specimen in which the rays extended over the disk to the anterior margin. 

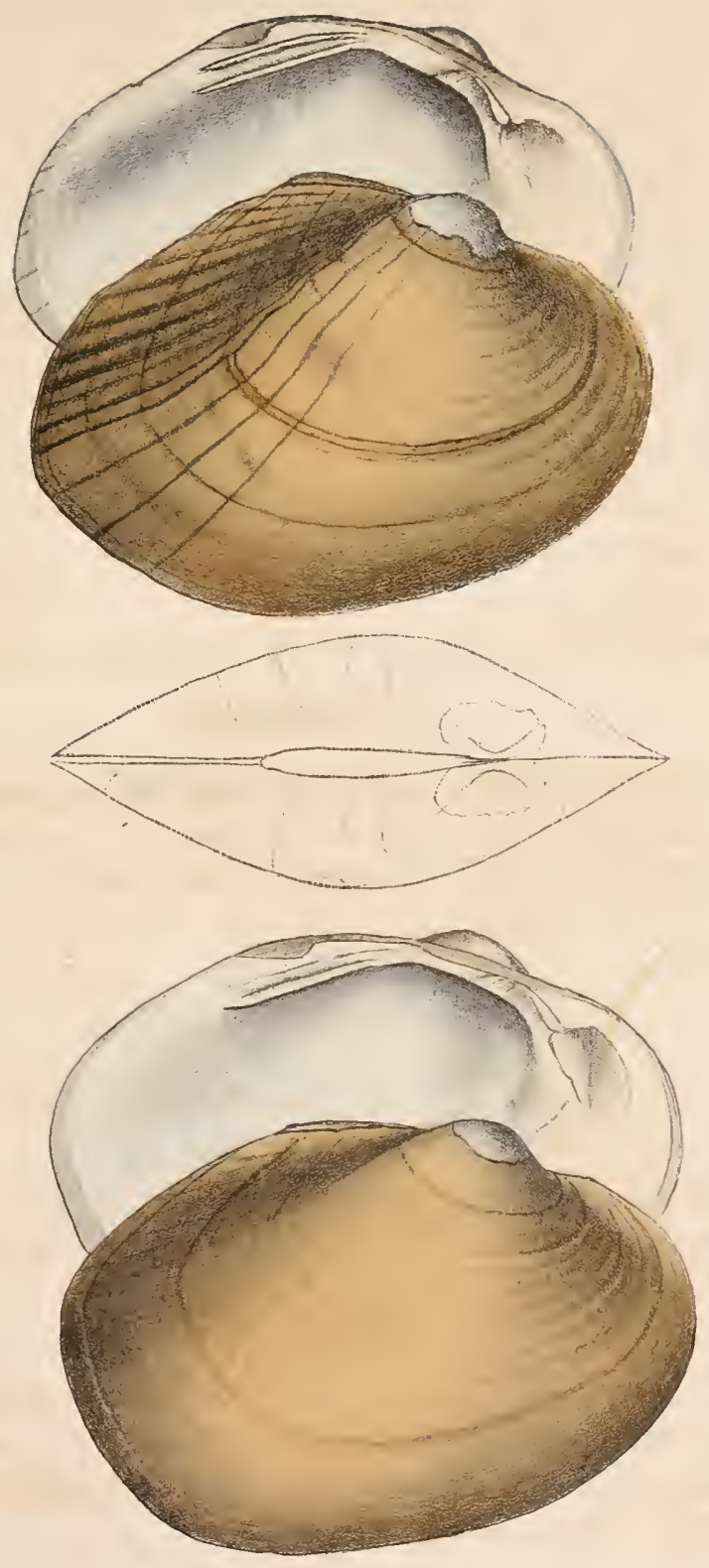




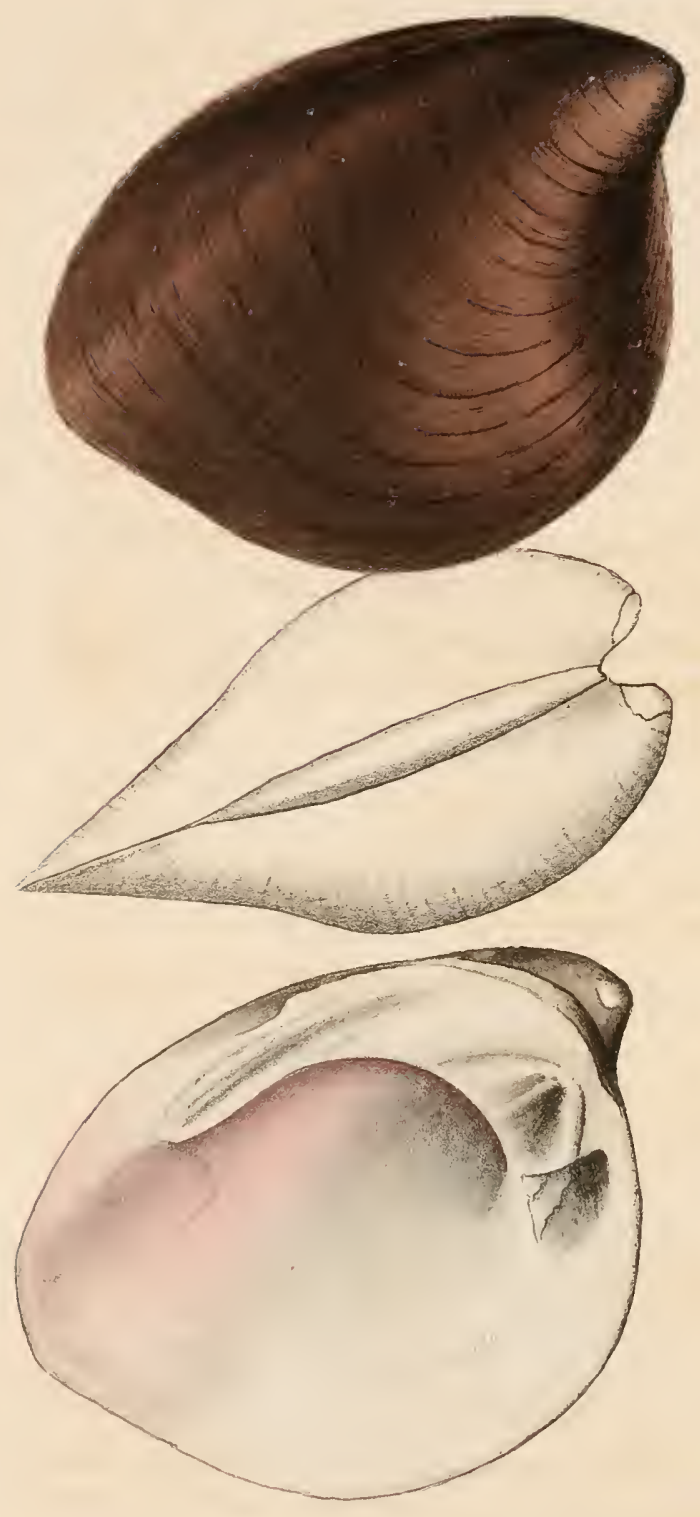

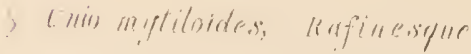




\title{
UNIO MYTILOIDES.
}

\author{
Plate XX.
}

\section{DESCRIPTION.}

Shell elevated, subtriangular; epidermis reddishbrown, with crowded wrinkles; posterior side with a broad furrow; anterior side gibbous; umbo tapering, curved, narrowed at the summit, which is much elevated; lunule obtusely cordate; within white, purple, and iridescent towards the posterior extremity; cardinal teeth large, very thick, prominent, sulcated; posterior muscular impressions impressed, the smaller one profoundly.

\section{SYNONYMES.}

U. mytileides, Raf. Ann. gen. des Sc. Phys. vol.v.p. 47. pl. 82. fig. 8. Poulson's trans. p. 53.

U. RUBRA, $R u f$.

U. pyramidatus, Lea. Trans. Amer. Philos. Soc., new series, vol. iv. p. 109, pl. xvi. fig. 39.

U. caridiacea, Say of Guérin.

Cab. A. N. S. No. 2017.

\section{OBSERVATIONS.}

This common species, since its first discovery in the western waters, has always been known by the name we have adopted. It is nearly allied to $\boldsymbol{U}$.cor, Nob., and $\boldsymbol{U}$. undatus, Barnes, but is very distinct, although its varieties are intricate and perplexing. Young specimens are very short and greatly elevated, and frequently rayed; old shells are compressed, cu- 
neiform, and produced posteriorly; the rays confined to the umbo and obsolete. Inhabits the Alabama and Black Warrior rivers.

\section{UNIO DILATATUS.}

\section{Plate XXI.}

\section{DESCRIPTION.}

Shell ovato-elliptical, thick and ponderous, slightly sinuous; posterior side produced, compressed, cuneiform; umbo broad, flattened, summit obtusely rounded; anterior lunule large, elliptical; umbonial slope angulated, not very distant from the margin; basal margin slightly contracted near the middle; within obliquely sulcated from the umbo towards the posterior basal margin; colour purple, with a bluish margin; cardinal teeth thick, direct; lateral teeth very thick, and terminating rather abruptly.

\section{SYNONYMES.}

U. Dilatatus, Ruf. Ann. gen. des Sc. Phys. vol.v.p. 31. Poulson's trans. p. 25. SAx, Amer. Conch. No. 6. Ferr. Mag. de Zool.

U. Nasutus, Lam. An. sans vert, vol. vi. p. 75 .

U. gibbosus, Barnes. Silliman's Journ. vol. vi. p. 262.

Cab. A. N. S. No. 1072 .

OBSERVATIONS.

In outline this species approaches $\boldsymbol{U}$. fasciolaris, but "differs in the much less dilated cardinal plate, in having the anterior [posterior] smaller muscular im- 


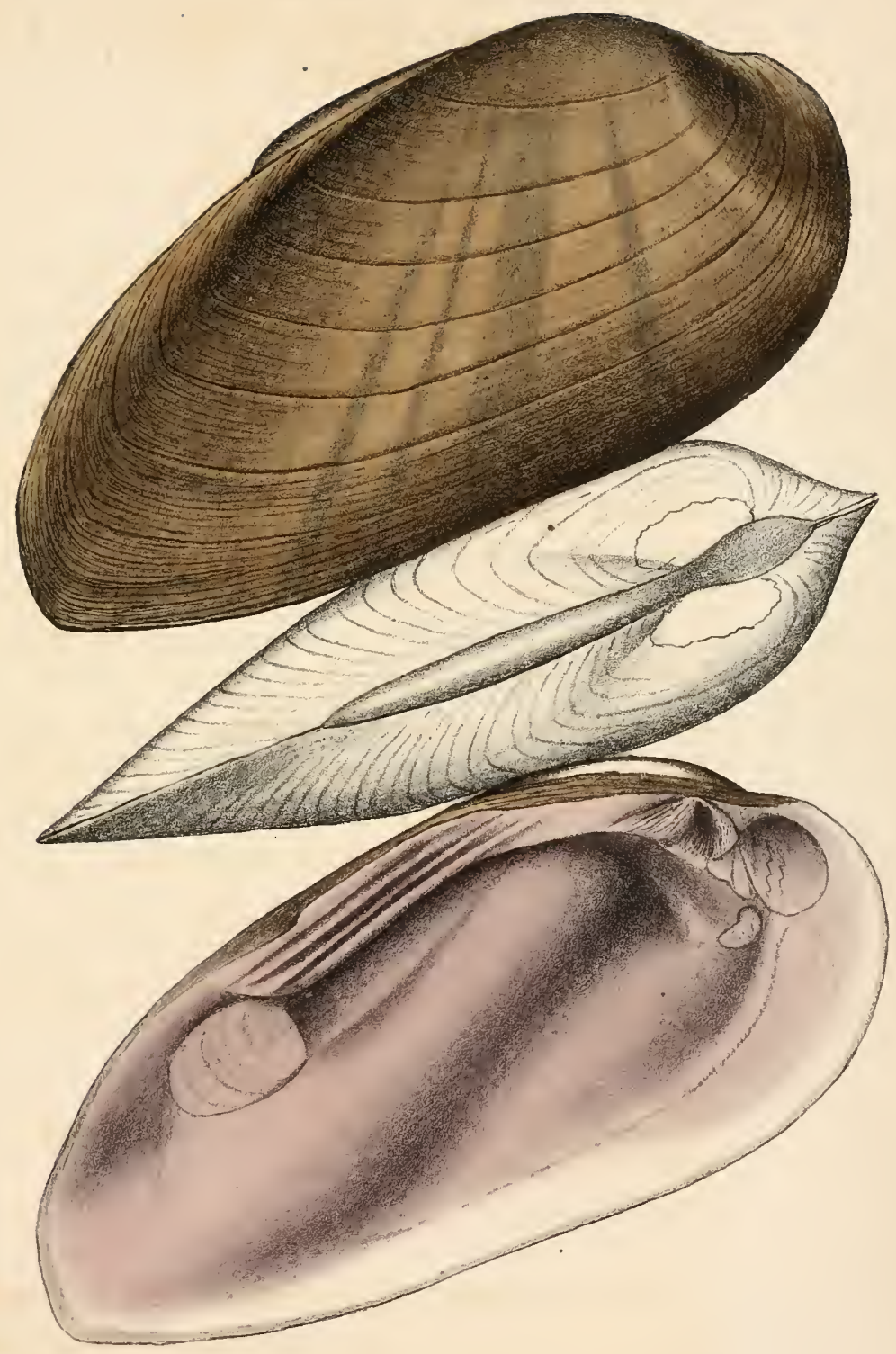

- T'nis dilutatus, Rafinesoue. 



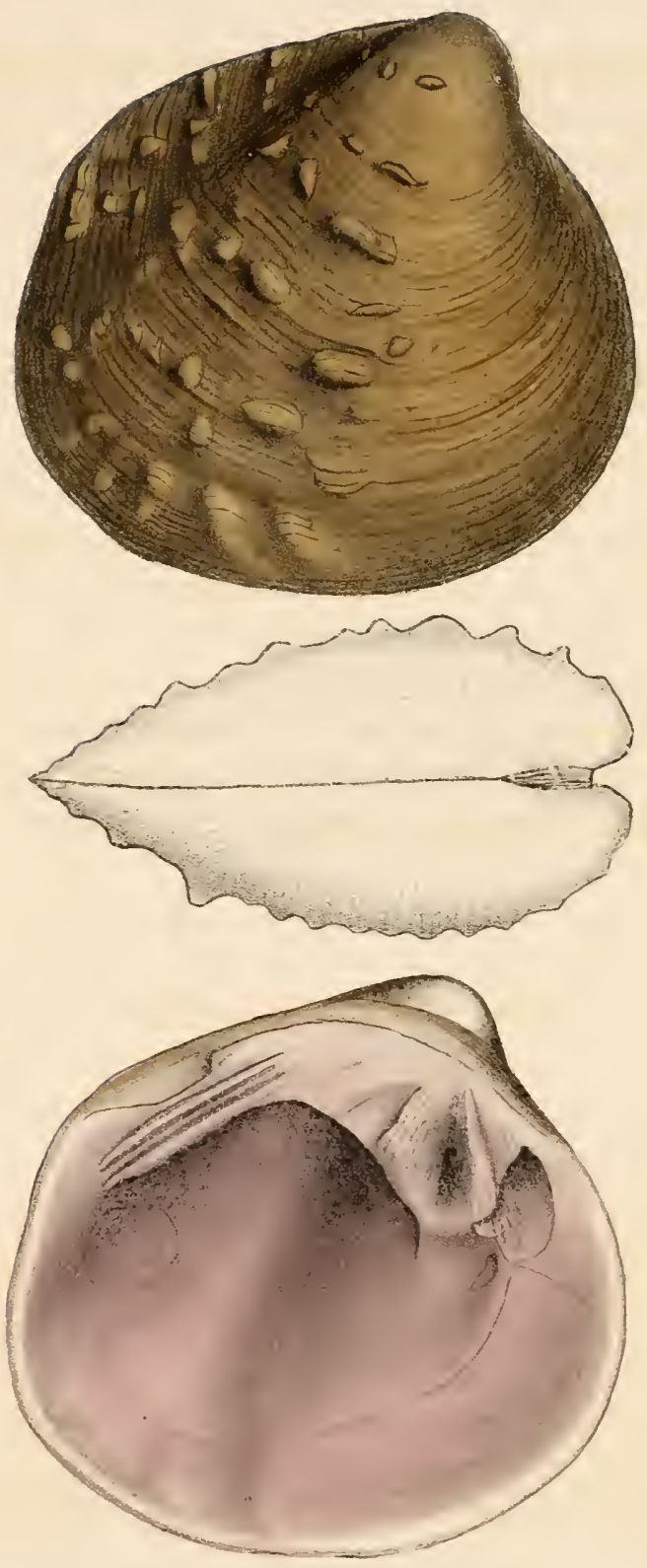

Inis tuberrulatus. $\checkmark$ Raf. 
pression situated immediately beneath the tip of the lamelliform teeth, in having the anterior [posterior] lunule much more depressed, with slightly elevated lines crossing the wrinkles." "* It also differs in having a purple interior, varying from an intense shade of that colour, approaching an indigo blue, to a pale reddish-purple. The great thickness of the superior portion of the shell causes the eavity of the umbo to be very shallow.

Common in the tributaries of the Ohio, Upper Mississippi, and Missouri. In Alabama, I found it only in the Tennessee and its tributaries. It is a common species in the mountainous region of North Carolina and Virginia, where, from a poverty of calcareous matter, it is always comparatively small. $\boldsymbol{U}$. cuprea and $\boldsymbol{U}$. atroviolacea, $\mathrm{R}_{\mathrm{AF}}$., appear from the descriptions to be mere varieties of $\boldsymbol{U}$. dilatatus.

\section{UNIO TUBERCULATUS.}

\section{Plate XXII.}

DESCRIPTION.

Shell subquadrangular, convex, thick; disk covered with irregular tubercles, except towards the anterior margin; tubercles largest near the centre of the disk; anterior margin obtusely rounded; posterior margin direct, emarginate; anterior lunule elliptical, profound; umbo narrow, very prominent; beaks pointed, approximate, but generally eroded or worn in maturity;

$$
\text { * Say. Amer. Conch. pl. } 22 .
$$


umbonial slope angulated; basal margin arcuate; epidermis green olive, with green capillary rays over the umbo; within chocolate colour; cardinal teeth very large, direct, prominent, trifid in the right valve; cavity of the beak very profound.

SYNONYMES.

U. tuberculatus, Raf. \$nn. gen. des Sc. Phys. vol. v. p. 42. Say. Amer. Conch. No. 6. Ferr. Mag. de Zool.

U. verrucosus, Bames. Silliman's Journ. vol. vi. p. 125, pl. 5, fig. 6.

U. tuberculosa, Valenc.

Cab.A. N. S. No. 1430.

OBSERVATIONS.

Some varieties of this species closely resemble $U$. bullatus exteriorly, but independent of other characters, the chocolate coloured interior, which, though sometimes pale, never wholly disappears, will at once distinguish the present species from all its congeners. It is a very variable shell; some specimens from the Harpeth river, 'Tennessee, being much dilated and compressed, and the ligament margin so much elevated as to give the posterior side an alated appearance. Other specimens are far more elevated in proportion to their length, and the posterior sulcus and emargination profound. 'These great differences may be sexual characters, but require an anatomical investigation of the animal to settle that point.

Common in the western rivers, and inhabits Lake Erie and the Ouisconsin, according to Mr. Barnes. It is not found in Alabama south of the Tennessee river and its tributaries. 

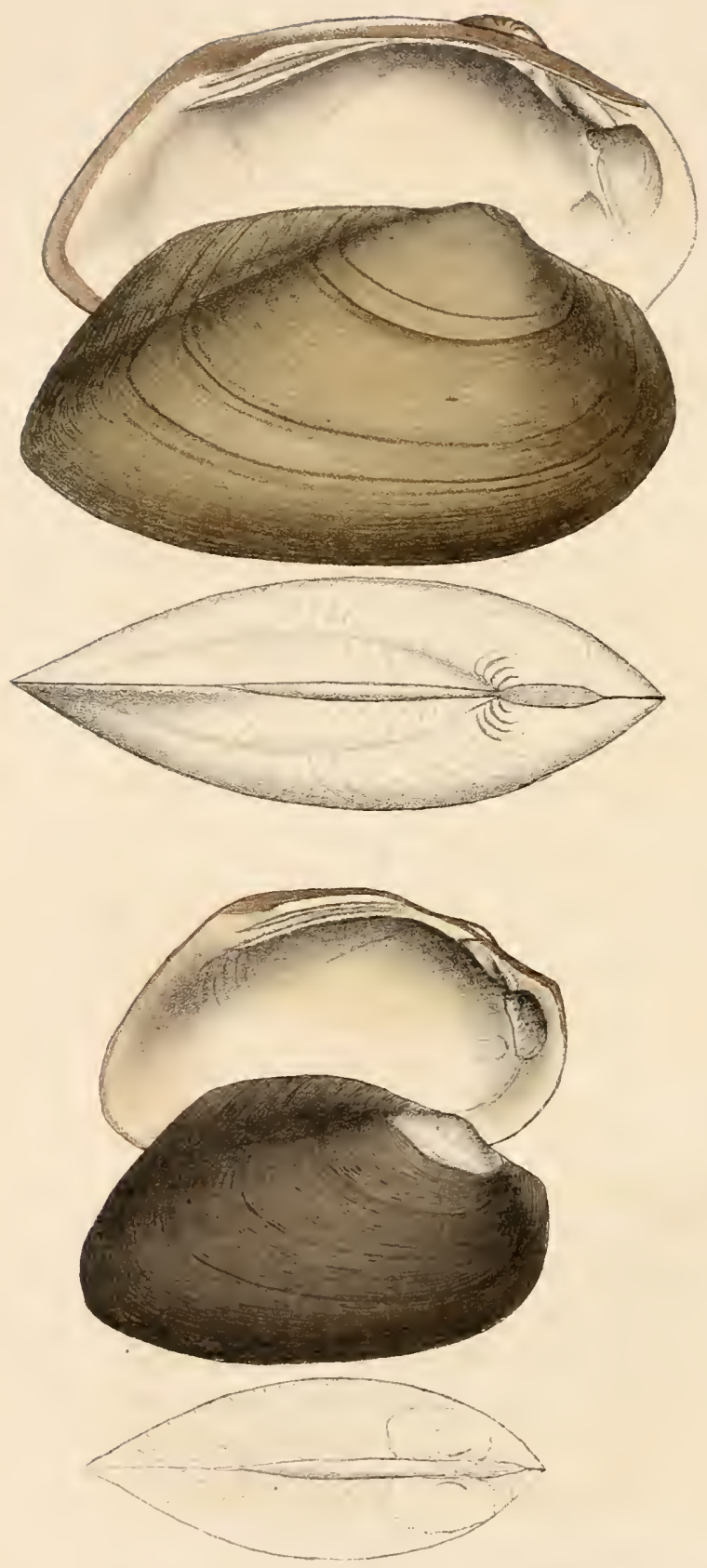

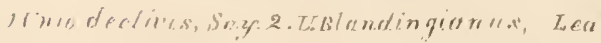




\title{
UNIO DECLIVIS.
}

\author{
Plate XXIII.-Fig. 1.
}

DESCRIPTION.

Shell trapezoidal, moderately thick; anterior margin obtusely rounded; beaks slightly elevated, with oblique undulations; hinge margin rather elevated and compressed, angulated at tip; posterior margin rectilinear, descending obliquely to a prominent rostrum of the posterior basal margin at the extremity of the umbonial slope; umbonial slope abruptly rounded, and bounded on its posterior side by two slightly impressed lines; basal margin arcuate; surface deeply wrinkled; within tinged with purplish; cardinal teeth oblique; lateral teeth distant from the cardinal teeth.

SYNONYMES.

U. Declivis, Say. Trans. Journ. vol. iv. p. 527, Amer. Conch. pl. 35.

U. geometricus, Lea. Trans. Amer. Philos. Soc. new series, vol. v. p. 38 , pl. 4, fig. 10.

Cab. A. N. S. No. 1875 .

OBSERVATIONS.

This species resembles a variety of the complanatus in its general form, and its teeth and posterior angle are somewhat similar to those of nasutus. It is very distinct from either. The figure is from a fine specimen which $\mathbf{I}$ found in a small creek in Greene county, Alabama, where the species is abundant, but usually more compressed than the one I have selected for representation. I was unable to find a specimen in 
any of the large rivers. It is common in Bayou Teche, Louisiana, and has been found in the Ohio canal near Louisville, whence Mr. Hyde has received it.

\title{
UNIO BLANDINGIANUS.
}

\author{
Plate XXIII.-Fig. 2.
}

DESCRIPTION.

Shell subtrapezoidal, rather thin, ventricose; anterior margin very obtusely rounded; ligament margin much elevated, slightly arcuate, angulated at tip, posterior margin long, oblique and rectilinear; extremity subtruncated or obtusely rounded; beaks slightly elevated, eroded; umbonial slope rounded, very distant from the margin; epidermis finely wrinkled; within purplish, with green stains; cardinal teeth small, single in the right valve and compressed; widely bifid, and rather obtuse in the left; lateral teeth distant from the cardinal teeth, and arcuate; anterior muscular impressions marginal.

\section{SYNONYME.}

U. Blandragranus, Lea. Trans. Amer. Philos. Soc. new series, vol. v. p. 101, pl. xv. fig. 44.

Cab. A. N. S. No. 1859.

OBSERVATIONS.

A species allied to complanatus and declivis, but differing from both in the elevated ligament margin and inflated disks. The anterior lunule resembles 
21
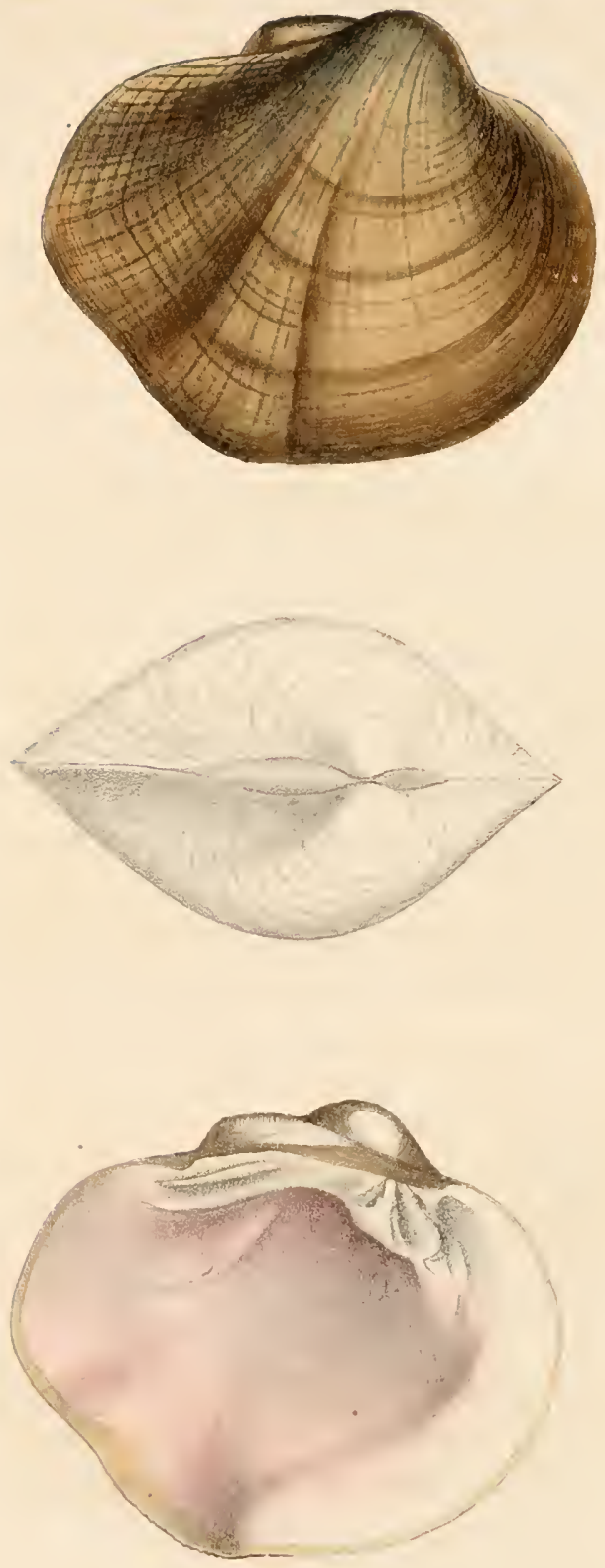

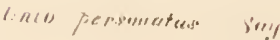

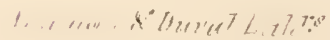


that of the preceding species. It was obtained in East Florida, from an Indian, by Dr. Blanding, and to this worthy naturalist the species has been properly dedicated.

\title{
UNIO PERSONATUS.
}

\author{
Plate XXIV.
}

DESCRIPTION.

Shell sublenticular; length rather more than the height; anterior margin forming with the basal margin a regular curve to the termination of the umbonial slope; posterior side narrowed; posterior margin subtruncated; umbo rounded, very prominent, submedial; umbonial slope swelling near the base, gaping and denticulate on the margin; epidermis with numerous capillary rays, profound and undulated on the posterior side; within pink; cardinal teeth direct, thick, prominent; lateral teeth slightly recurved; cavity of the beak not profound.

\section{SYNONYMES.}

U. personatus, Suy. New Harmony Disseminator, p. 509, 1829. U. capillaris, Lea. Trans. Amer. Philos. Soc. new series, vol. v. p. 29, pl. 2, fig. 2, 1832.

Cab. A. N. S. No. 1382.

\section{OBSERVATIONS.}

It would seem from the observations of Dr. Kirtland, that all those Uniones which have the peculiar denticulated and dilated base, are female shells; and 
if so, we are unacquainted with the male personatus. The exterior somewhat resembles $U$. lavigatus, and the cardinal teeth are very like those of $U$. nexus; Say's description applies only to the immature shell. For the use of the splendid specimen here represented and described, we are indebted to G. W. Featherstonhaugh, Esq., who procured it from Cumberland river, Tennessee. Mr. Say's specimens were from the Wabash.

\section{UNIO CORDATUS.}

\section{Plate XXV. \\ DESCRIPTION.}

Shell subtriangular, not oblique, length and height nearly equal; beaks distant from the anterior margin, prominent, incurved and pointed; anterior lunule very broad and obtusely obovate, beneath which is a flattened cordate space with the opposite margin rectilinear; inferior portion of the anterior margin regularly rounded to the middle of the basal margin, which is emarginate and ascending posteriorly; sinus of the posterior side not oblique, slightly arcuate; posterior margin rounded above, angulated at its junction with the basal margin; epidernis fuscous, witl green interrupted rays over the umbo; within white.

\section{SYNONYME.}

U. condatus, Raf. Ann. gen. des Sc. Phys. vol,v.p. 46. Poulson's tians. p. 52.

Cab. A. N. S. No. 2018. 


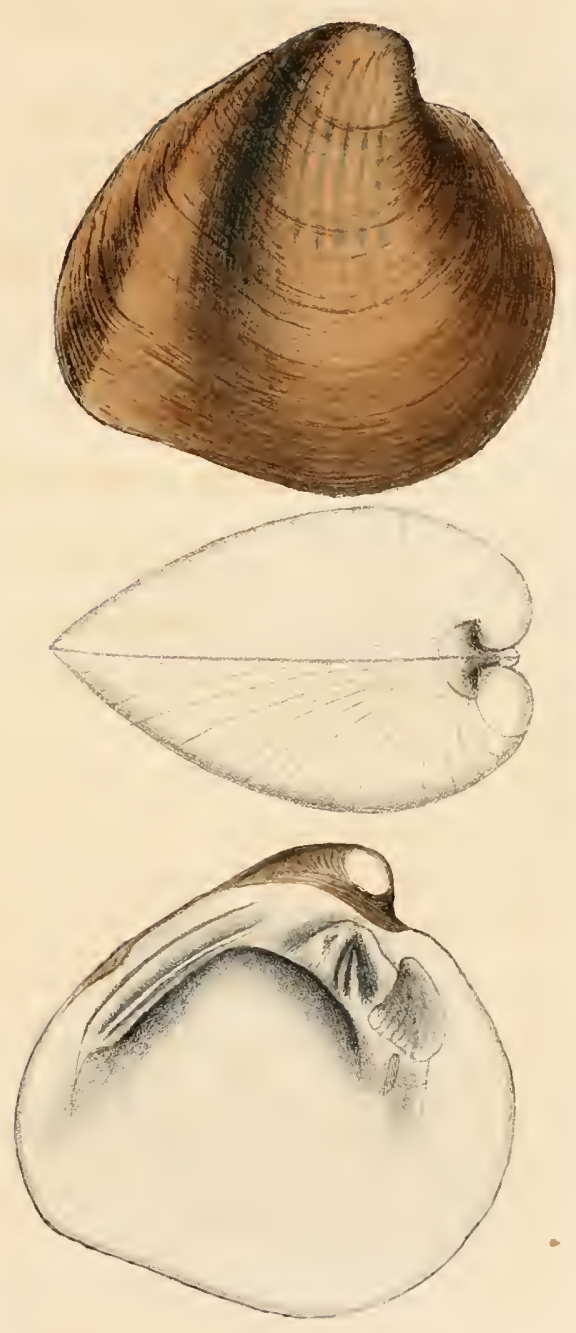

film rortal"d, firfinesyue. 




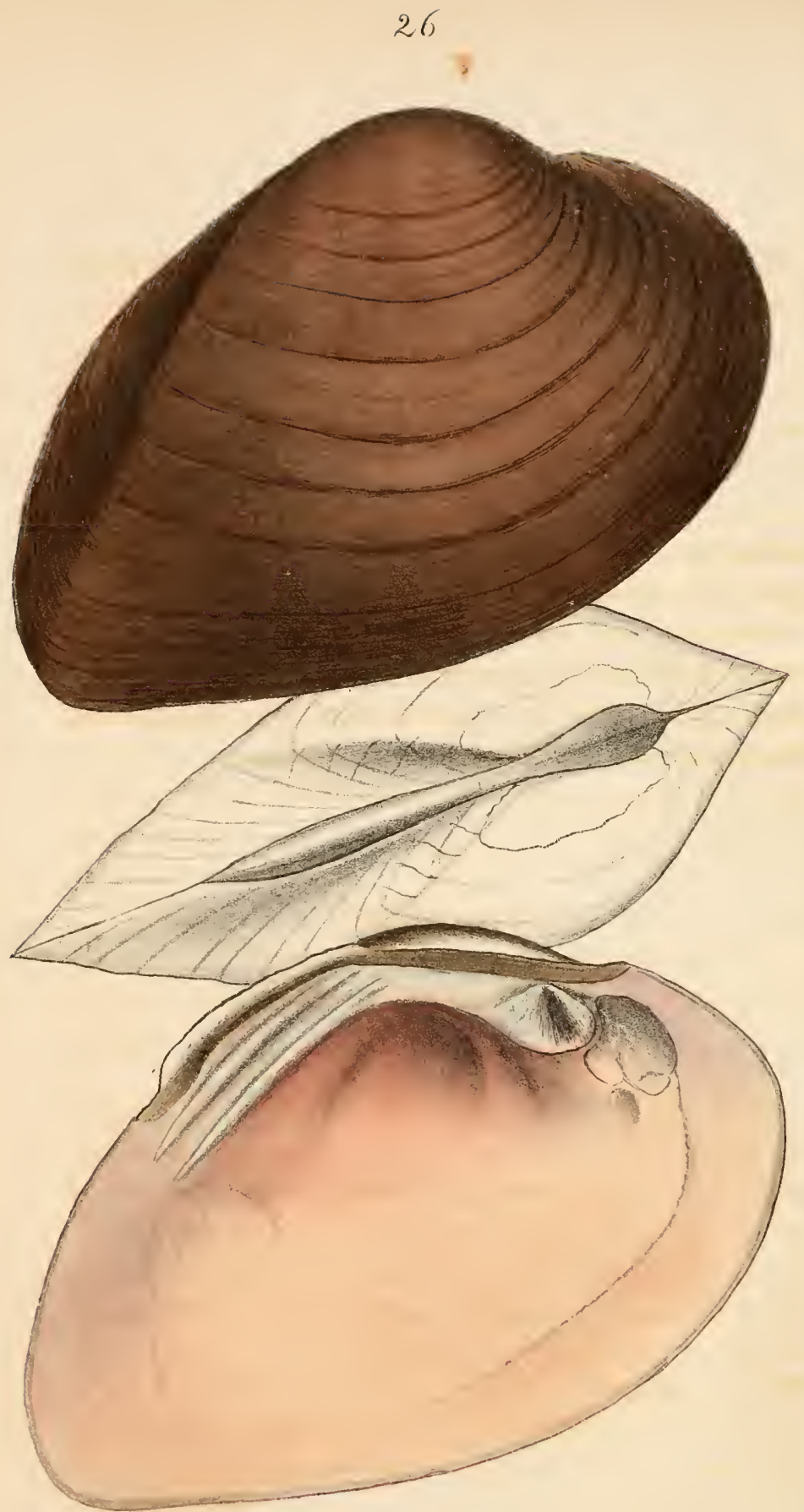

t Lnon wiger $^{2} R \| f$ 
OBSERVATIONS.

I formerly supposed this shell a variety of mytiloides, but the differences are so constant in a great number of specimens, that it may be useful to introduce it to conchologists by the name which Rafinesque has bestowed upon it. It differs from mytiloides in not being oblique, in being about as long as it is high, in having the beaks distant from the anterior margin, and never in any stage of growth having the posterior side prolonged obliquely downwards.

Inhabits the Ohio and its tributaries. The specimen figured belongs to the cabinet of Mr. Featherstonhaugh, and is from Cumberland river, Tennessee. It connects $\boldsymbol{U}$. mytiloides with $\boldsymbol{U}$. undatus.

\section{UNIO NIGER.}

\section{Plate XXVI.}

DESCRIPTION.

Shell elliptical; with age, subovate, or subtriangular; thick and ponderous; disks somewhat flattened; posterior lunule with short, oblique, vermicular raised lines; posterior side compressed, cuneiform; umbo broad, flattened, summit obtusely rounded; umbonial slope angulated; epidermis reddish-brown, frequently rayed; within purple or salmon colour; cardinal teeth direct, prominent; lateral teeth thick, distant from the cardinal teeth; posterior muscular impression slightly impressed; cavity of the beak shallow. 
SYNONYMES.

U. niger, Ruf. Ann. gen. des Sc. Phys. vol. v. p. 25. Poulson's trans. p. 15. Say. Amer. Conch. No.6. Ferr. Mag. de Zool.

U. CRASSIDENS, var. b. Lam.

U. cuneatus, Barnes. Silliman's Journ. vol. vi. p. 263.

Cab. A. N. S. No. 2400, 2401, 2402.

OBSEKVATIONS.

In the observations on $\boldsymbol{U}$. congarceus, I compared that species with the niger, but however the young of both may resemble each other exteriorly, the cardinal teeth of the latter are always more robust and less oblique, and the interior very often dark purple, which is never the case with the congarcus. It differs most obviously from $\boldsymbol{U}$. dilatatus, in being comparatively much shorter, and in the raised lines on the posterior lunule.

Common in the western streams, and very abundant in the Black Warrior and Alabama rivers. In Detroit river, Michigan, it has been obtained by Dr. Sager.

\section{UNIO GIBBOSUS.}

Plate XXVII.-Fig. 1.

DESCRIPTION.

Shell subovate, oblique, with a submedial nodulous ridge projecting at base; concentric sulci very distinct; posterior side with a wide furrow; umbonial slope angulated; umbo prominent; posterior end and 


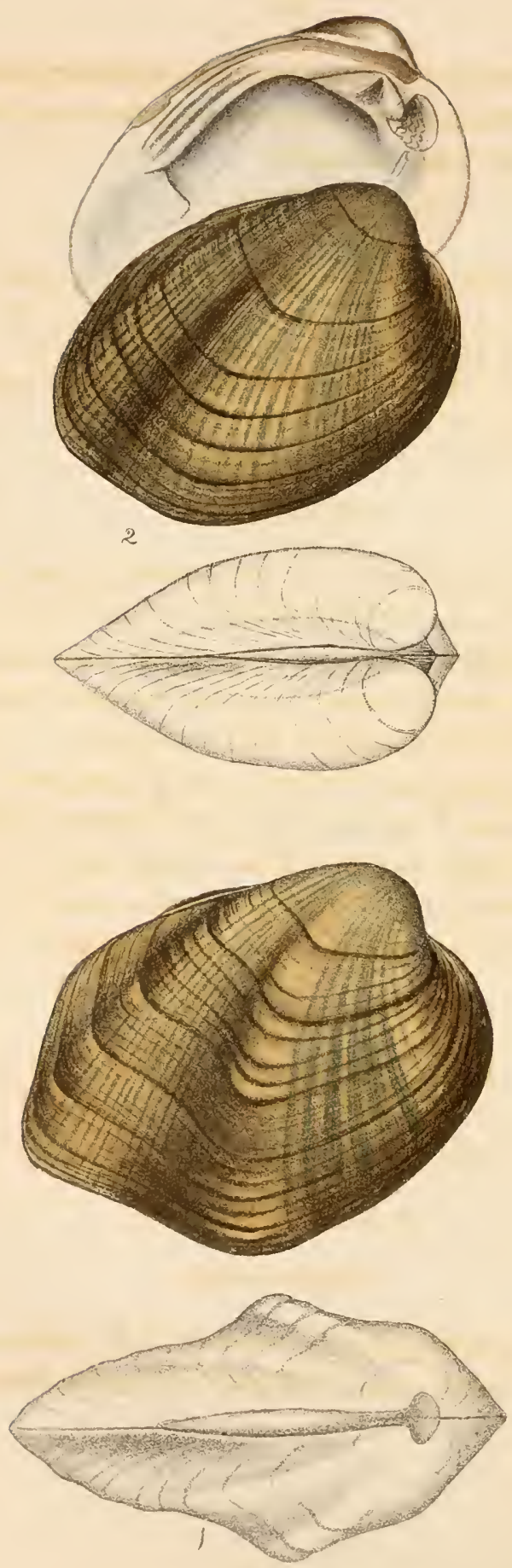
posterior basal margin emarginate; epidermis smooth, shining, yellowish with numerous green rays; within white, rarely rose coloured.

\section{SYNONYMES.}

U. grbbosus, Raf. Ann. gen. des Sc. Phys. vol. v. p. 49. Poulson's trans. p. 56 .

U. torulosus, Raf. Ib. p. 48 . Poulson's trans. p. 56.

U. Perplexus, Lea. 'Trans. Amer. Philos. Soc. new series, vol. iv. p. 122, pl. 17 , fig. 42.

Cab. A. N. S. No. 1051.

OBSERVATIONS.

Besides its affinity with the preceding species, this shell has a general resemblance to three others, with none of which, however, can it be confounded by those who are familiar with the subject; these are $U$.flexuosus, $\boldsymbol{U}$. Phillipsii, and $\boldsymbol{U}$. reflexus.

Common in the Wabash and Scioto, and $I$ have found it in the Tennessee river, at Florence, Alabama, but not farther south. The female may be readily distinguished by the dilated margin, which is more profound in this species than in any other.

\section{UNIO GIBBOSUS.}

VARIETY PEROBLIQUUS.

Plate XXVII.-Fig. 2.

OBSERVATIONS.

This is perhaps a mere variety of $\boldsymbol{U}$. gibbosus, Raf., but it is much more oblique, the beaks nearer the 
anterior extremity, the posterior basal emargination much less profound, and the central tubercles are obsolete; in outline it closely resembles $\boldsymbol{U}$. obliquatus, but that species is always of a purple colour within, though the tint is sometimes pale.

Inhabits the Wabash river, Indiana, and Detroit river, Michigan.

\section{UNIO TERES.}

\section{Plate XXVili.}

DESCRIPTION.

Shell narrow—elliptical, subcylindrical, moderately thick; umbo slightly prominent; summit obtusely rounded; umbonial slope abruptly rounded, submarginal; posterior side produced, cuneiform; epidermis yellowish and polished, rarely rayed; within white or pale salmon colour; cardinal teeth double in each valve, subcompressed, very erect; lateral teeth distant from the cardinal teeth.

SYNONYMES.

U. teres, Raf. Ann. gen. des Sc. Phys. vol.v. p. 55. Poulson's trans. p. 68.

U. Anodontoides, Lea. Trans. Amer. Philos. Soc., new series, vol. iv. p. 91, pl. viii. fig. 11.

Cab. A. N. S. No. 1383.

OBSERVATIONS.

A well characterized species, approaching the rcctus in outline, but is comparatively shorter and emi- 


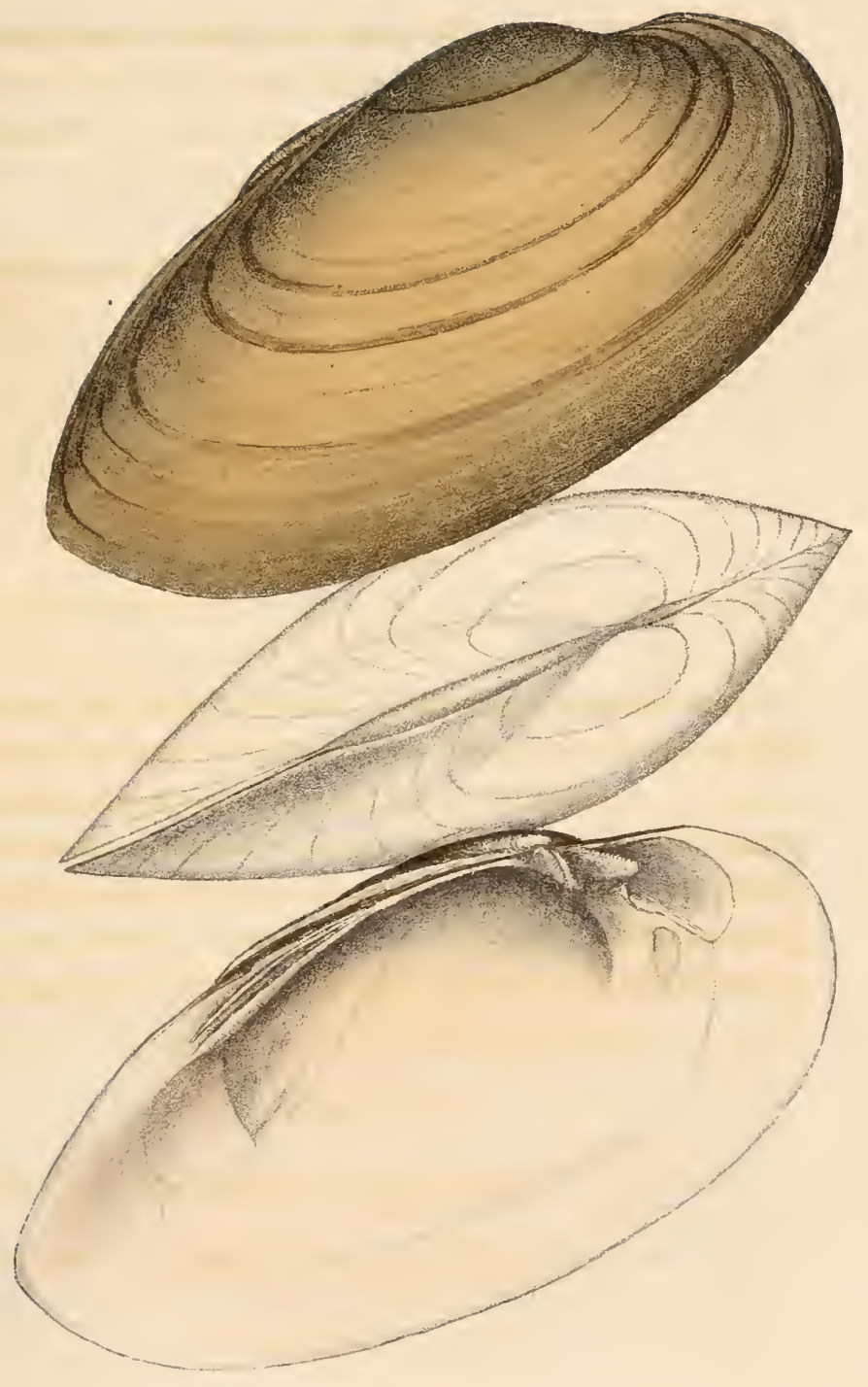

t inno teres. $R a g$. 

nently distinguished by the peculiarity of its pale epidermis. The sexes are well marked by difference of outline.

Not uncommon in the Western rivers, and in Bayou Teche, Louisiana, where it is ornamented with pale green rays. In the Alabama river it is partial to a muddy bed, and rare on the bars.

I have figured a specimen in Mr. Poulson's cabinet, brought from the west and labelled by Rafinesque.

\section{UNIO SAGERI.}

\section{Plate XXIX.--Fig. 1.}

DESCRIPTION.

Shell narrow-elliptical, moderately thick on the anterior and thin on the posterior side; disks slightly contracted from beak to base, causing the basal margin to be slightly sinuous; anterior side short, margin regularly rounded; posterior side produced, somewhat pointed, extrem obtuse; ligament margin elevated; umbo not prominent, flattened; umbonial slope rounded; within bluish-white and iridescent; cardinal tooth in the right valve thick, direct, divided at the summit by a deep groove; in the left valve widely bifid, with a submedial lamelliform elevation; lateral teeth compressed.

\section{OBSERVATIONS.}

This interesting species was found in Detroit river, Michigan, by Dr. Abraham Sager, of Detroit, to whom 
I have a pleasure in dedicating it. The outline of a young specimen is very similar to a variety of $U$. dilatatus, but the thinness of the shell, colour of interior, and particularly the form of the teeth, will readily distinguish it. The old shell might perhaps be mistaken for a variety of the $U$.rectus, but the young has very little resemblance to that of the latter. $\boldsymbol{U}$. dilatatus is found in company with this species, retaining all the peculiarity of habit which it possesses in the Ohio and other tributaries of the Mississippi, which confirms our opinion that the shell we described above is new and distinct.

\section{UNIO LAPILLUS.}

\section{Plate XXIX.-Fig. 2.}

DESCRIPTION.

Shell suboval, thick, yellowish, with very numerous dark green undulated rays; anteriqur margin not very short, rounded; beaks but little elevated, simple; ligament margin declining gradually in an arcuate line; posterior extremity rounded; umbonial slope undefined; basal margin straight or slightly contracted in the middle; within pearly white; cardinal teeth direct, thick; lateral teeth thick, oblique; cicatrices very deep and rounded; cavity of the beaks almost obliterated.

\section{SYNONYMES.}

U. Laprluus, Say. Trans. Journ. of Med. vol. iv. p. 528, Amer. Conch. pl. 41. 

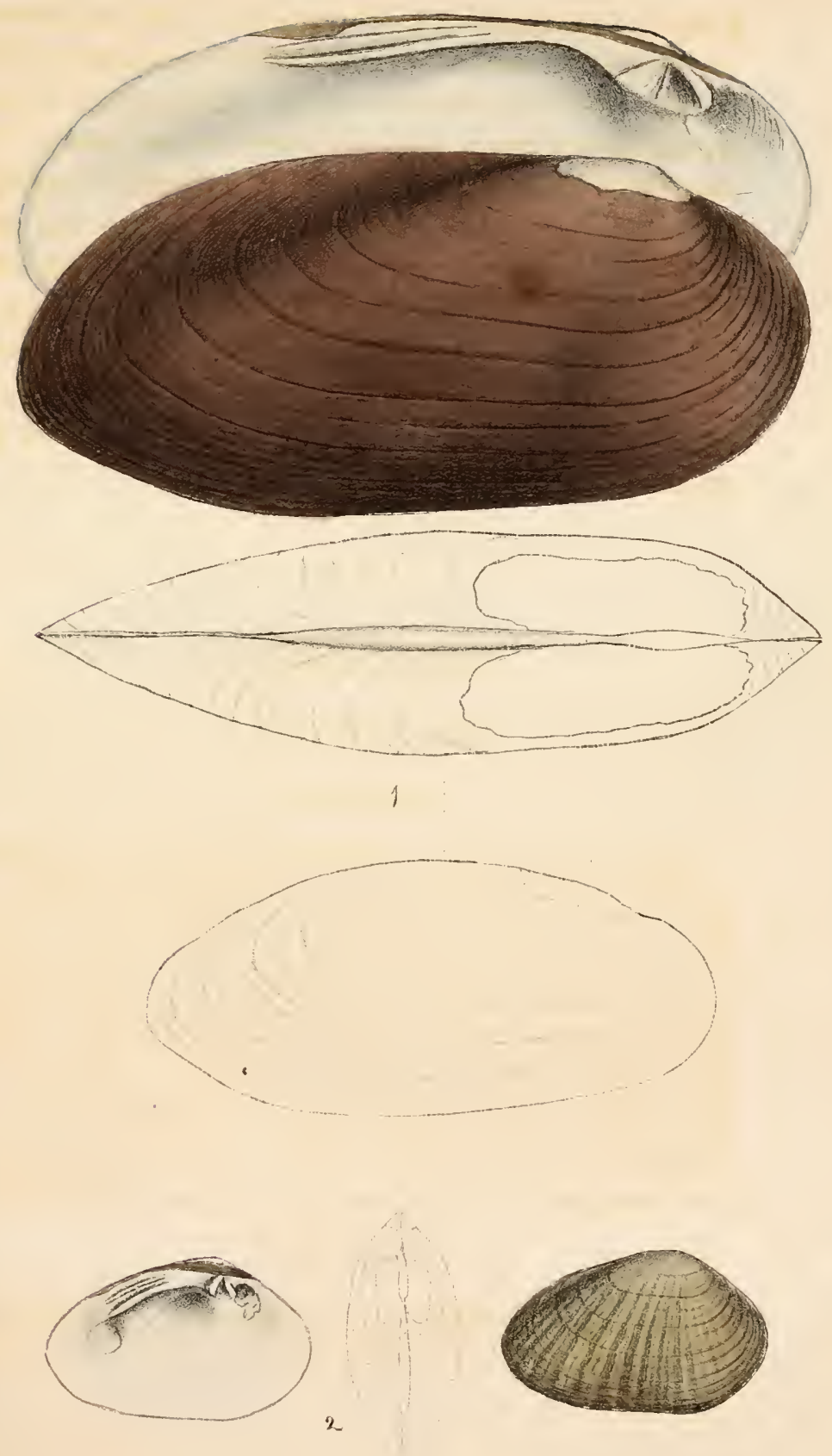

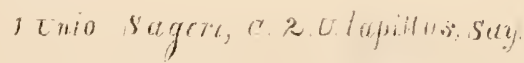




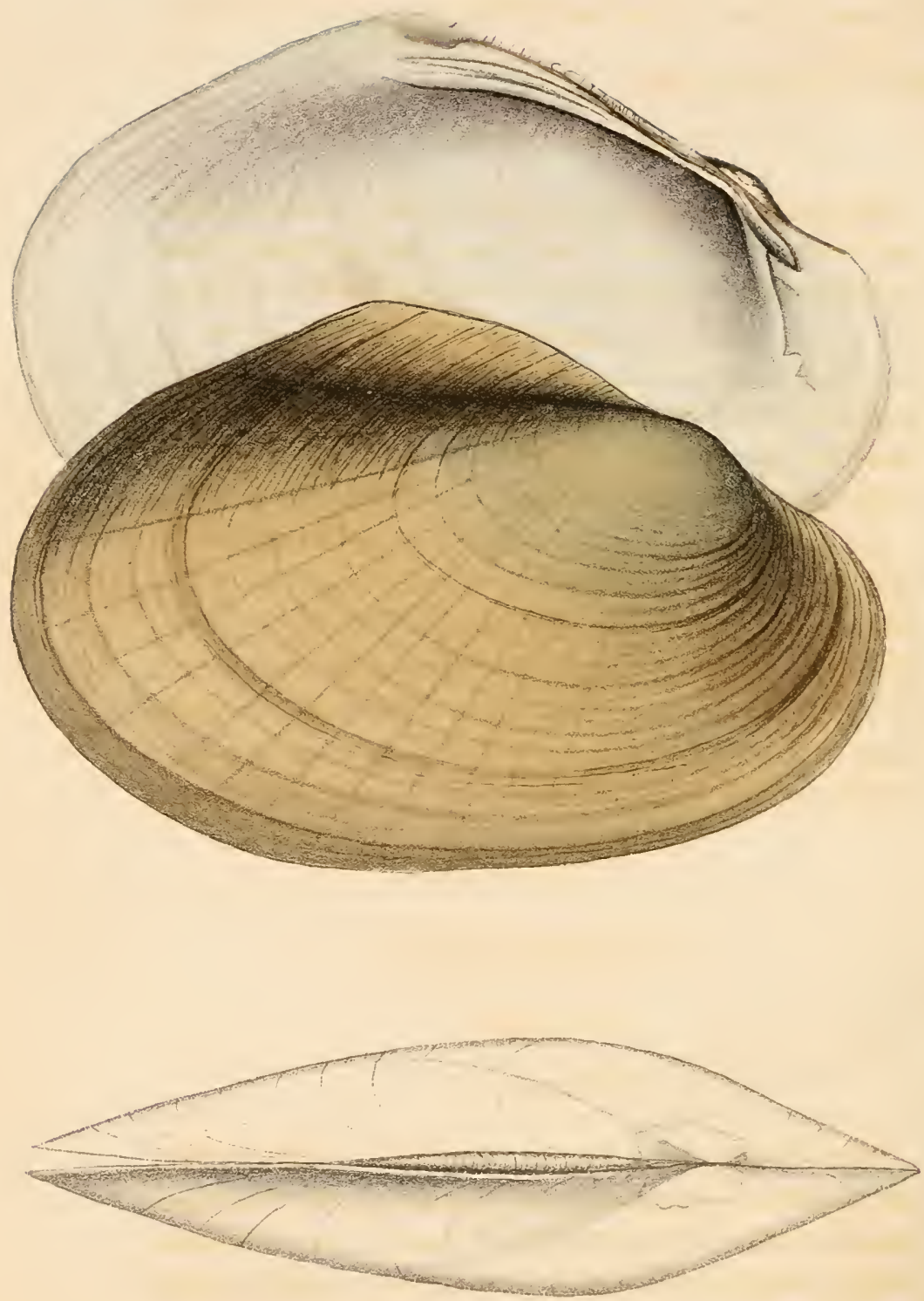

Tnofragilis, Ru 
U. fabalis, Lea. Trans. Amer. Philos. Soc. vol.iv. p. 96, pl. x. fig. 16.

Cab. A. N. S. No. 2404.

\section{OBSERVATIONS.}

Mr. Say observes that "the robust teeth and the thickness of the whole shell have induced many, and myself amongst the number, to consider this shell as the young of gibbosus, Barnes, [dilatatus, Raf.] but a very slight examination serves to show that it is very distinct. The young of that species is always much more elongated transversely, not so thick, with the beaks much undulated," \&c.

It is usually smaller than the specimen represented, and, except the acutissimus, is the least of North American Uniones yet described. Dr. Sager found it in Detroit river, Michigan, and it is not uncommon in the Ohio and its tributaries. The figure represents a fine specimen, of more than ordinary size, which we owe to the politeness of Professor J. Green.

\section{UNIO FRAGILIS.}

\section{Plate XXX.}

DESCRIPTION.

Shell ovate, thin, fragile, somewhat inflated over the umbonial slope; disks flattened towards the base; hinge margin elevated into a large wing, connate; within bluish and highly iridescent; cardinal teeth very oblique, compressed, disposed to be single in each valve; lateral teeth arcuate. 
U. fragilis, Ruf. Ann. gen. des Sc. Phys. vol. v. p. 29. Poulson's trans. p. 22. Say, Amer. Conch. No. 6.

U. gracilis, Barnes. Silliman's Journ. vol. vi. p. 174 .

U. Fragilis, Swains.

Sympinnota gracilis, Lea. Trans. Amer. Philos. Soc. new series, vol. iii. p. 66.

Cab. A. N. S. No. 1657 .

\section{OBSERVATIONS.}

Allied to $U$. alatus, but is longer in proportion, thinner, and lighter coloured in the interior and epidermis. In some localities the wing is small, but in others generally elevated.

Found by Mr. Schoolcraft in Fox river; it inhabits the Detroit river, Michigan, lakes, and the western rivers generally, and I found it common in the Alabama at Claiborne.

\section{UNIO ALATUS.}

\section{Plate XXXI. \\ DESCRIPTION.}

Shell triangular, ovate, moderately thick; disks flattened anteriorly, and inflated over the umbonial slópe; anterior side narrow, margin obliquely rectilinear above; posterior side profoundly dilated, and rising into an elevated connate wing; umbo oblique, inclined, not prominent; posterior lunule with two subangulated lines; umbonial slope regularly rounded; wing emarginate inferiorly; posterior end biangulated; 


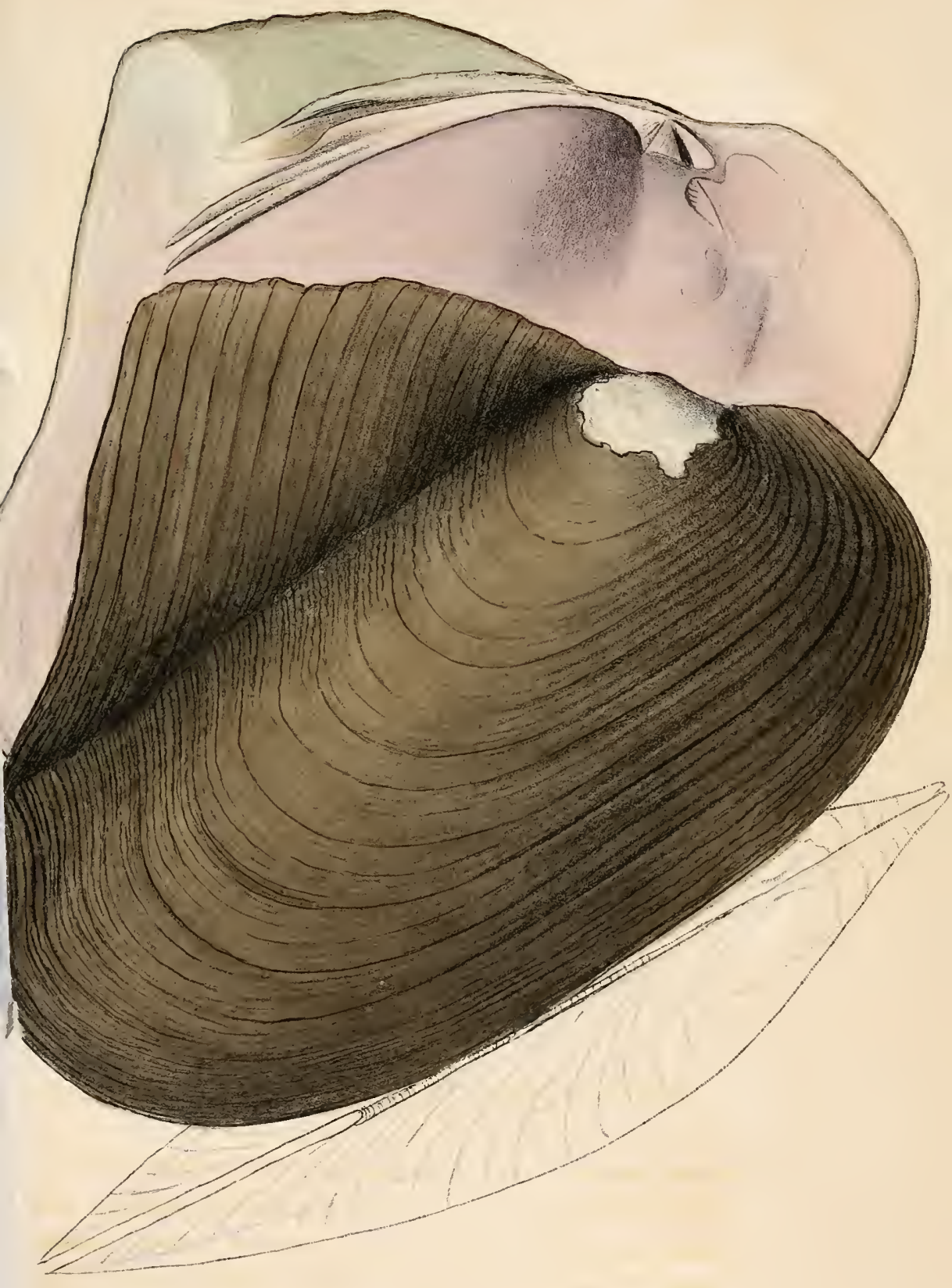




32

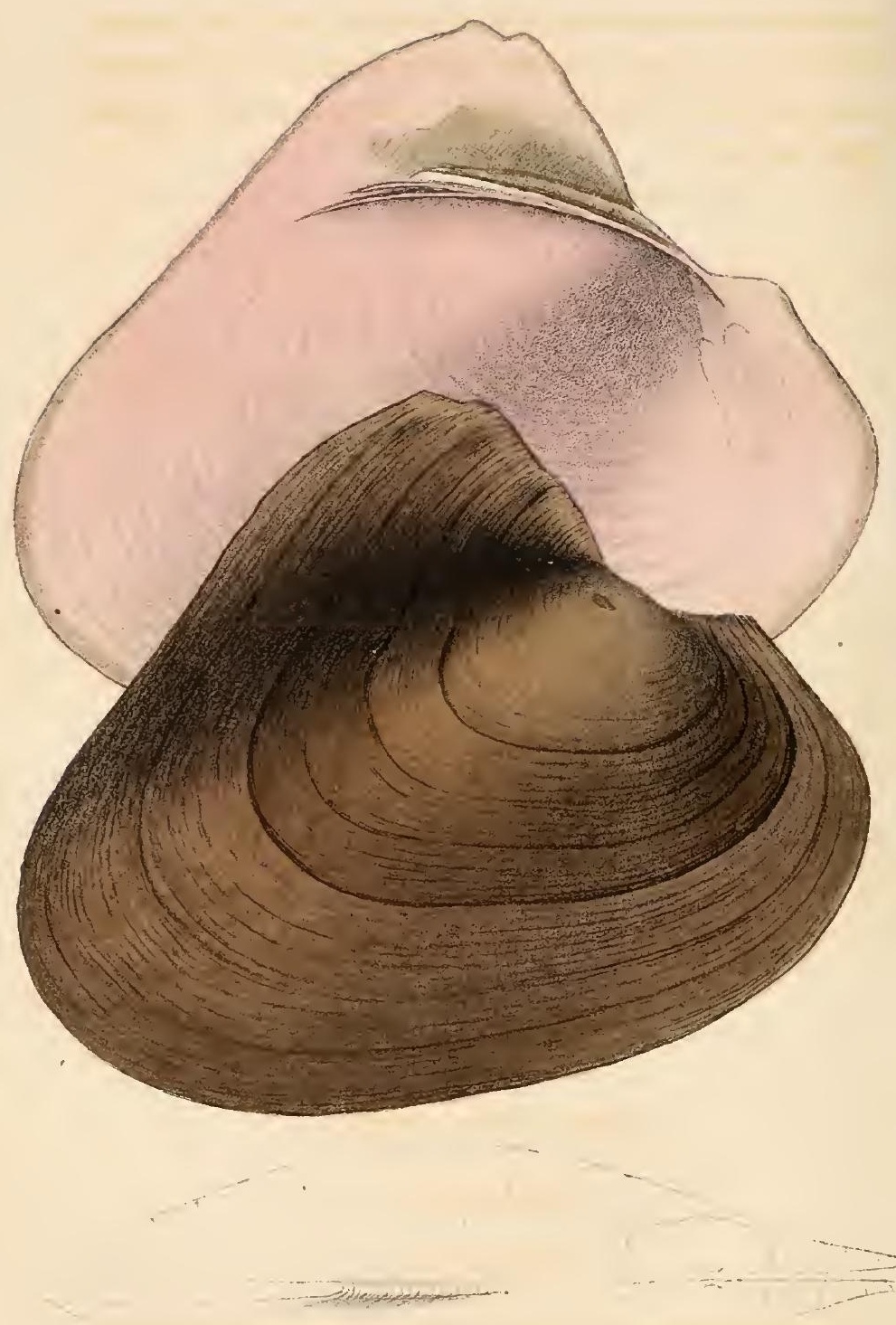


epidermis dark green-olive, wrinkled; wrinkles lamelliform posteriorly; within reddish-purple, iridescent; cardinal teeth direct, double in each valve; lateral teeth arcuate.

\section{SYNONYMES.}

U. alatus, Say. Nich. Enc., Am. ed., art. Conch.

U. (metaptera) megnptera, Raf. Ann. gen. des Sc. Phys., vol. v. p. 299.

Srmphynota alata, Lea. 'Trans. Amer. Phil. Soc., (new series,) vol. iii. p. 448.

Cab. A. N. S. No. 20409.

\section{OBSERVATIONS.}

This well known species approaches a variety of $\boldsymbol{U}$. purpuratus, Lam., but is less inflated and has a more elevated wing. From the fragilis it can be distinguished by its larger size, dark epidermis, purple nacre, thicker cardinal teeth, \&c.

Inhabits Fox and Ouisconsin rivers, North-West Territory, Mr. Barnes; Detroit river, Michigan, Dr. Sager; western streams generally, and the great lakes. It is extremely rare in South Alabama.

\section{UNIO INFLATUS.}

\section{Plate XXXil.}

DESCRIPTION.

Shell triangular, ovate, thin; contracted obliquely from beak to base; inflated over the umbonial slope; valves elevated into a small wing anteriorly and into 
a broad high wing posteriorly, and connate in botli; posterior margin of the wing arcuate, and sliglitly emarginate or angulated at base; beaks slightly prominent; cardinal teeth single in both valves, and lamelliform; lateral teeth arcuate, prominent towards the extremity; nacre purple.

SYNONYMES.

Sruphyota inflita, Lea. 'Trans. Amer. Phil. Soc., new series, vol. iv. p. 99, pl. xiv. fig. 28.

U. Arabamexsis, Nob. New Fresh Water Shells, p. 6r.

Cab.A.N. S. No. 20405.

OBSERVATIONS

Differs from $U$. (Symphynota) lavissimus in the inflated umbonial slope and more elevated wing. It was discovered near Claiborne, Alabama, by Judge Tait, and sent to Mr. Lea. I have since found it very abundantly a few miles soutl of Claiborne, but it is rare in the upper part of the Alabama and in the Black Warrior rivers, and has not hitherto been found elscwhere.

\section{UNIO LEPTODON.}

Plate XXXIII.

DESCRIPTION.

Shell narrow-elliptical, very thin and fiagile, compressed anteriorly, and slightly inflated over the unbonial slope; beaks very small, approximate; posterior 


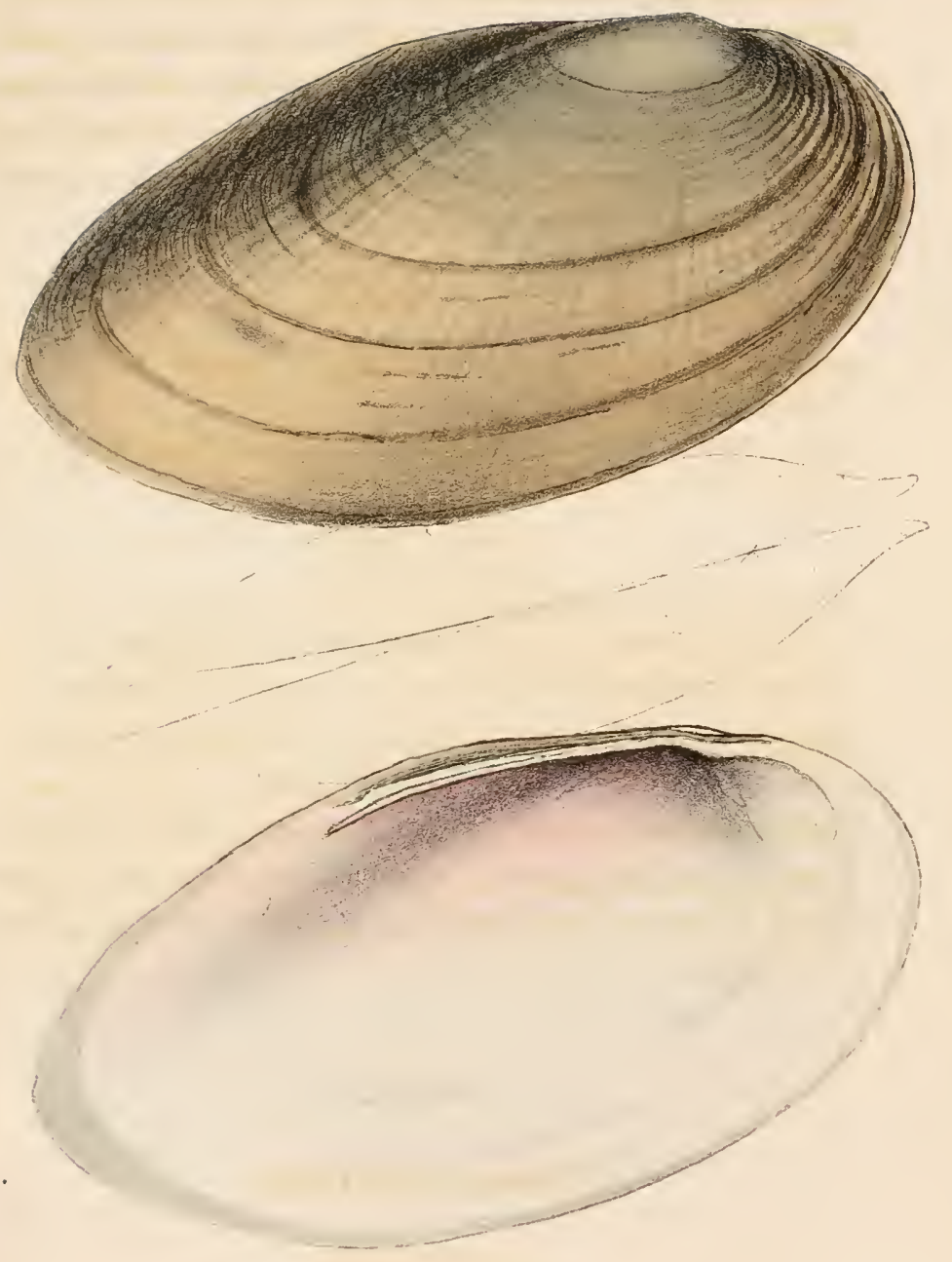

Unen leplodon, Ruf: 

side produced, pointed; hinge margin elevated; posterior margin very oblique, extremity acutely angular, and much above the line of the base; basal margin regularly arcuate; epidermis olive-yellow, with very oblique narrow rays; within bluish, tinged with violet above, highly iridescent; cardinal teeth obtuse, smooth, nearly obsolete; lateral teeth single in each valve.

\section{SYNONYMES.}

U. r.eptodox, Raf. Ann. gen. des Sc. Phys., vol. v. p. 295. Poulson's trans., p. 21. Say, Amer. Conch. No. 6. Ferr. Mag. de Zool.

U. planus, Barnes. Silliman's Journal, vol. vi. p. 272.

Anodonta purpurascens, Swainson.

Symphynota tenuissima, Leu. 'Trans. Amer, Philos. Soc., (new series,) vol. iii. p. 453 , pl. xi. fig. 21.

Cab. A. N. S. No. 20406.

OBSERVATIONS.

This shell has an exterior much resembling that of an Anodonta, but the teeth are generally sufficiently developed to constitute it a true Unio. It is allied to $U$. fragilis, but differs widely in the teeth, in being pointed posteriorly, and in not being alated. It is connate when perfect.

Inhabits the Ouisconsin, Mr. Barnes. I found a single specimen in Alabama. The specimen figured is from the Scioto river, and was presented by Dr. William Blanding. 


\title{
UNIO ELLIPSIFORMIS.
}

\author{
Plate XXXIV.-Fig. 1.
}

\section{DESCRIPTION.}

Shell elliptical, slightly ventricose, produced posteriorly, moderately thick; disks slightly contracted anteriorly; umbonial slope rounded; beaks slightly prominent, approximate, simple; basal margin dilated posteriorly to the middle; within bluish; cardinal teeth thick, direct.

\section{OBSERVATIONS.}

This species I have seen only in the cabinet of Mr. John Phillips, who received it from Michigan. It is very similar in outline to $\boldsymbol{U}$. lienosus, but the short, thick, direct teeth, simple beaks, and bluish nacre, form a very distinctive character.

\section{UNIO LIENOSUS.}

\section{Plate XXXIV.--Fig. 2.}

DESCRIPTION.

Shell elliptical, inflated, slightly furrowed or contracted from beak to base; substance of the shell thickened towards the base; posterior dorsal and posterior basal margin rounded, extremity subangulated; beaks pointed, approximate, slightly prominent, 

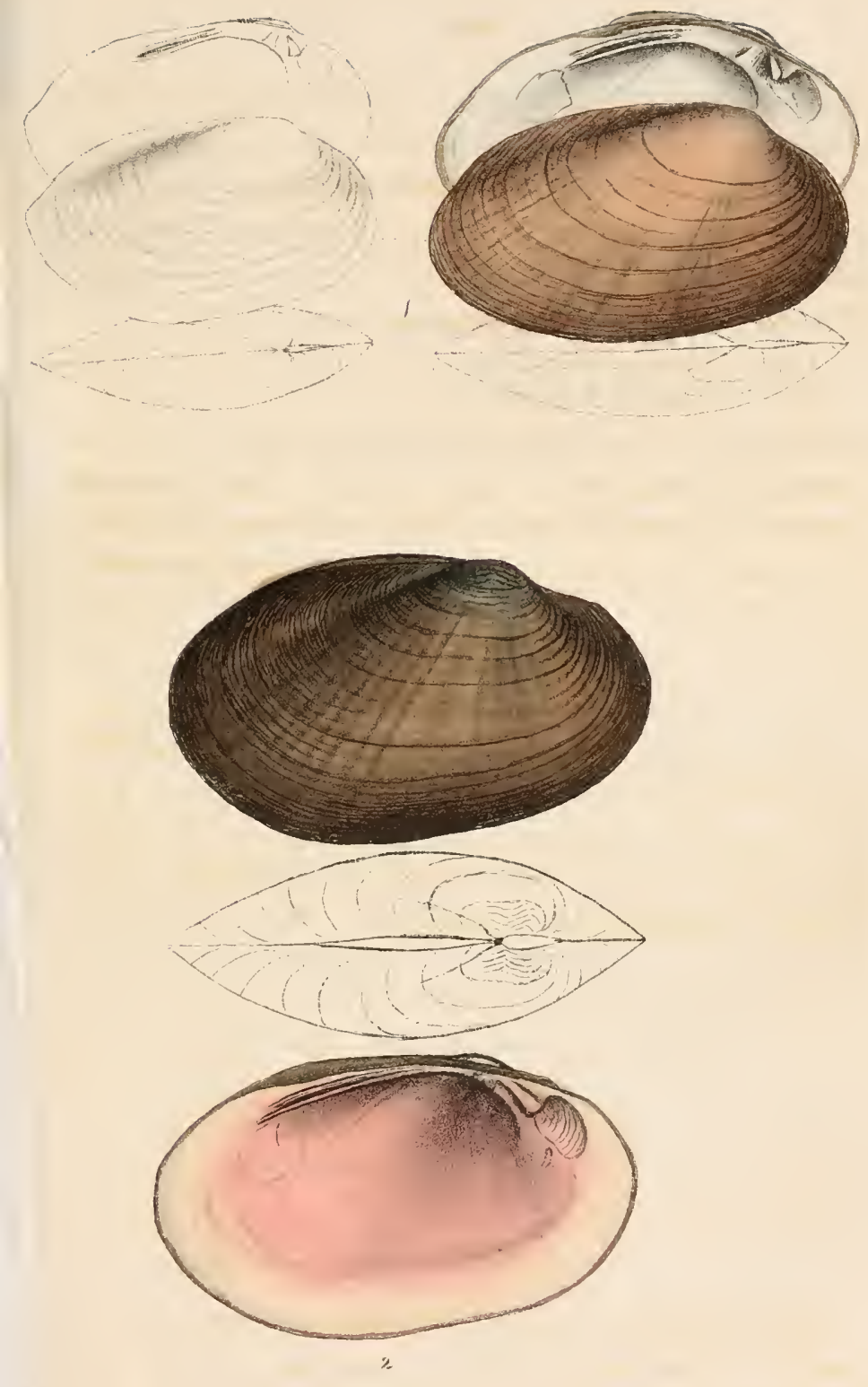

1. Unio ellipsiformis, C. Z. V.lienostus, C. 

with interrupted undulations; concentric lines prominent; epidermis dark olive, obscurely rayed, wrinkled on the margins; cardinal teeth double in both valves, slightly compressed, oblique, striated; nacre varying from bluish white to deep salmon or purple; cavity most capacious under the umbonial slope.

SYNONYMES.

U. Lienosus, Nob. Silliman's Journal, vol. xxv. p. 339, pl. 1, fig. 4.

U. Nashvillyanus, Lea. Trans. Amer. Phil. Soc., (new series, vol. v. p. 100, pl. xiv. fig. 43.

Cab. A. N. S. No. 20407.

\section{OBSERVATIONS.}

This shell is remarkable for inhabiting exclusively the small streams, and is common in Greene county, Alabama. It is a variable species, sometimes not easily recognised, and the sexual distinctions are as obvious as in $\boldsymbol{U}$. siliquoideus. The colour of the interior is remarkably inconstant, but a purple approaching to salmon is the most prevailing tint, and the margin is bluish-white. The affinities are $U$. parvus, Barnes, and $\boldsymbol{U}$. glans, Lea, but it is much larger than either, has very different beaks, and does not inhabit the same waters with those species. 

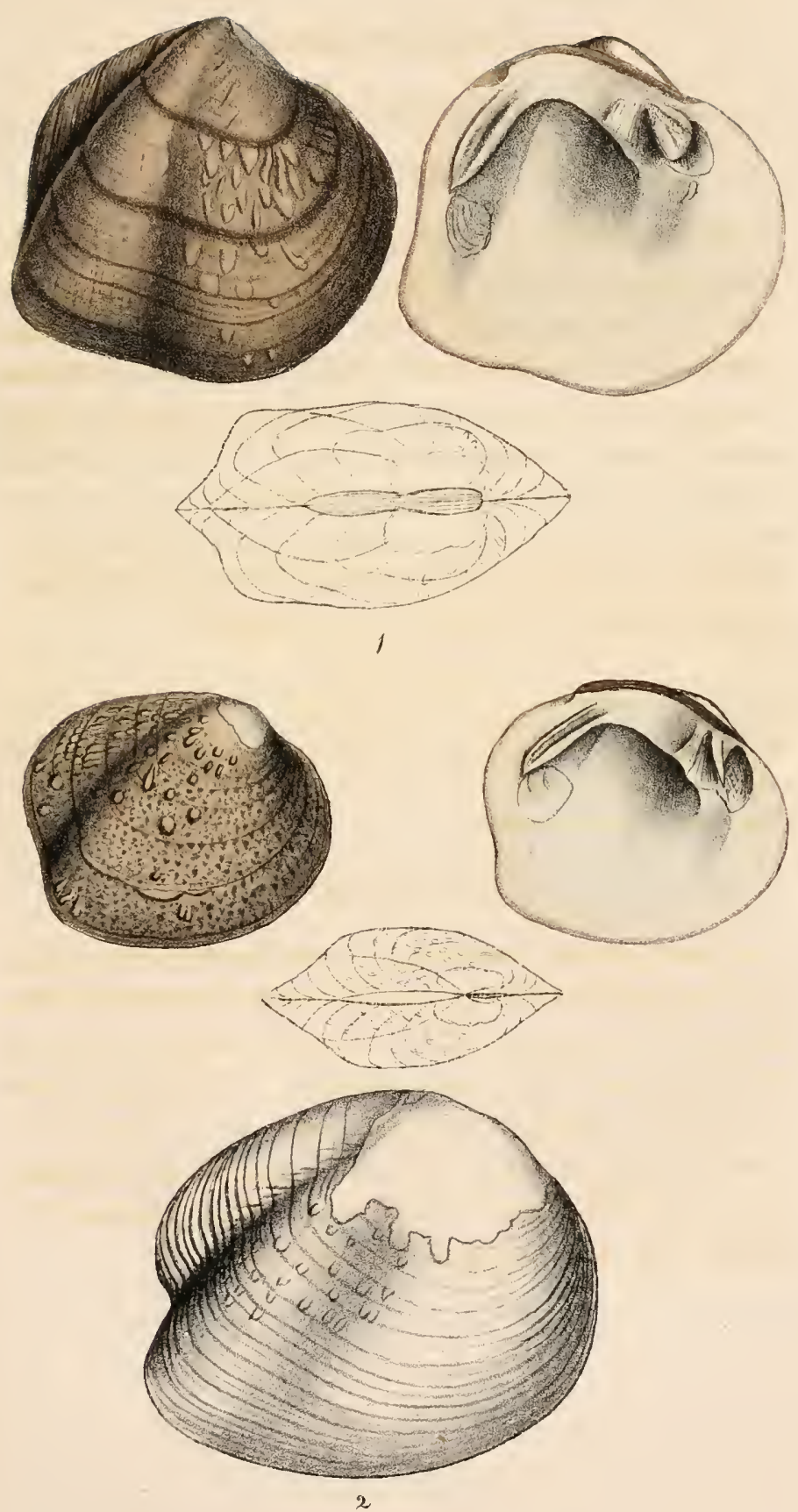

2

1. Unio stupes Led 2. Tintermedius. conrad. 



\title{
UNIO INTERMEDIUS.
}

\author{
Plate XXXV.-Fig. 2.
}

DESCRIPTION.

Shell suboval, compressed; disks flattened or slightly furrowed from beaks to base, covered, except on the posterior side, with small slightly elevated tubercles, which are rib-shaped on the posterior slope; umbonial slope not prominent, and rounded or subangulated; posterior slope obtusely angulated; beaks oblique, not prominent; ligament margin long, arcuate; posterior margin direct, emarginate; within white; cardinal teeth direct.

\section{OBSERVATIONS.}

Three specimens of this species were obtained by Dr. S. Blanding, of Columbia, S. C., from Nolachucky river, Tennessee, and were kindly submitted to my inspection. They differ from the preceding in being somewhat oblique, in having less prominent beaks, a wider posterior slope, but particularly in being destitute of tubercles anteriorly. From the metanevra it is easily distinguished by the want of a swelled umbonial slope. It is so evident a link between these two species, that $I$ have given it the name of intermedius, suggested by my friend Mr. John Phillips. In a young specimen which I have figured, the epidermis is covered with small crowded angular green spots, but in the old shell they disappear. The latter becomes distinctly angulated or furrowed on the pos- 
terior slope, and profoundly emarginate posteriorly, as represented in the outline, fig. 3 .

\title{
UNIO OCCIDENTALIS.
}

\author{
Plate XXXVI.-Fig. 1.
}

DESCRIPTION.

Shell elliptical, convex, anterior margin very regularly rounded; anterior dorsal margin elevated; basal margin straight and parallel with the ligament margin; posterior margin oblique, extremity rounded; umbonial slope undefined; beaks slightly prominent, with undulated grooves; summit rounded; epidermis yellowish, with narrow green rays, which are obsolete or wanting on the anterior side; within bluish; cardinal teeth direct, prominent, acute; lateral teeth lamelliform.

\section{OBSERVATIONS.}

This shell has an outline similar to that of $U$.complanatus. It differs from that species in its yellow epidermis, the peculiarity of its rays, more elevated anterior margin, lamelliform lateral teeth, \&c.

Inhabits Currant river, Arkansas, whence it was brought by Mr. Featherstonhaugh, to whose kindness I owe the use of this and several rare and beautiful species. 

36
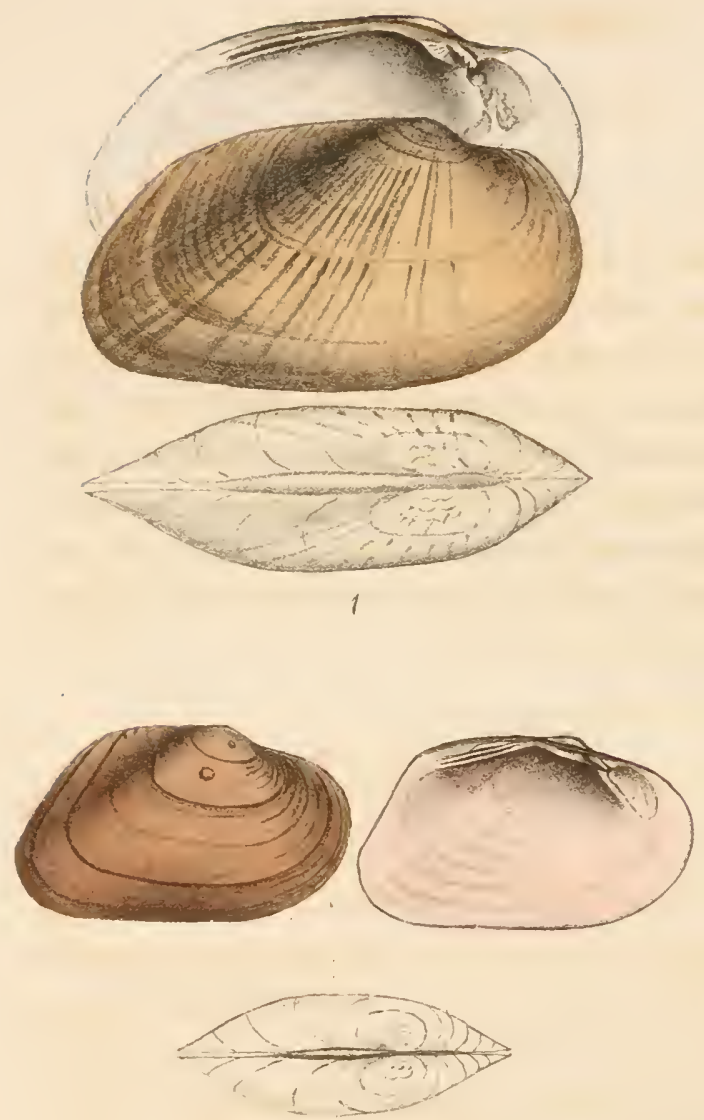

2

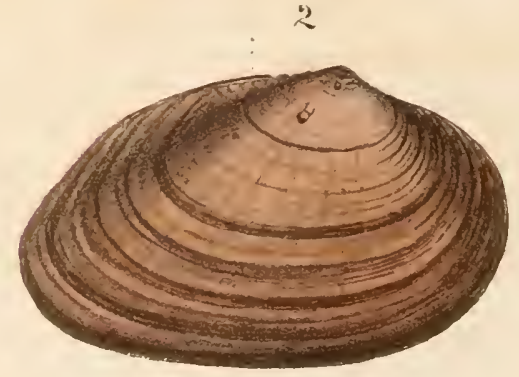

I. Inin occidentrlis, $c$ 2. U. collinus, con. 


\title{
UNIO COLLINUS.
}

\author{
Plate XXXVI.-Fig. 2.
}

\section{DESCRIPTION.}

Shell elliptical, rather thin, with coarse concentric lines; umbonial slope rounded; posterior side slightly produced, and rapidly narrowed to the extremity, which is rounded; basal margin straight near the middle; beaks small, slightly prominent, approximate, undulated; umbones with two or three small tubercles posterior to the middle; epidermis yellowish-brown, obscurely rayed; within white or pale rose colour; cardinal teeth oblique, robust.

Cab. A. N. S. No. 20408.

\section{OESERVATIONS.}

This species may readily be known by the small tubercles on the umbones. The female, when young, closely resembles $\boldsymbol{U}$. heterodon in outline, but the usual formation of the lateral teeth and the tubercles eminently distinguish it. Inhabits North river, a branch of James river, Virginia, where it was found by Mr. Constant Newkirk, of Washington College, from whom I received three specimens. 


\title{
UNIO SOWERBIANUS.
}

\author{
Plate XXXVII.--Fig. 1.
}

\section{DESCRIPTION.}

Shell ovate, convex, with concentric furrows; disks slightly gibbose in the middle; posterior side with a furrow from beak to base; a slight groove on the posterior submargin; raised radiating lines extend from the angle of the larger furrow to the posterior extremity, which is direct and slightly retuse; basal margin retuse posteriorly; epidermis glabrous, with faint filiform brown rays; within purple or rose colour; cardinal teeth very large and prominent, double in each valve.

\section{SYNONYME.}

U. sowerbianus, Lea. Trans. Amer. Phil. Soc., new series, vol. v. p. 68, pl. x. fig. 28 .

\section{OBSERVATIONS.}

The fine specimen of this beautiful and very distinct species which I have figured, was kindly loaned for the purpose by Mr. Featherstonhaugh, who procured it from Cumberland river, Tennessee. I found one in the sunimer of 1833 on the bank of Elk river, Alabama, and judging from Mr. Lea's figure of the pileus, I supposed it to be that species.* The specimen is in the cabinet of Mr. Poulson.

The Sowerbianus is remarkable for its highly polished epidermis and raised lines on the posterior side.

* New Fresh Water Shells, p. 69, note. 

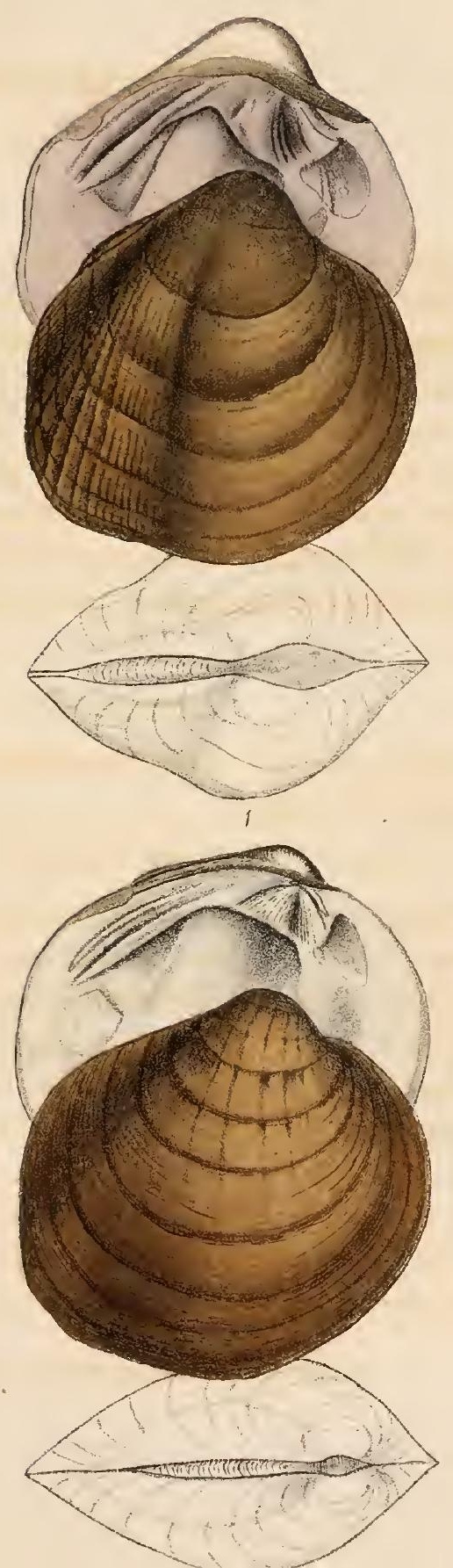


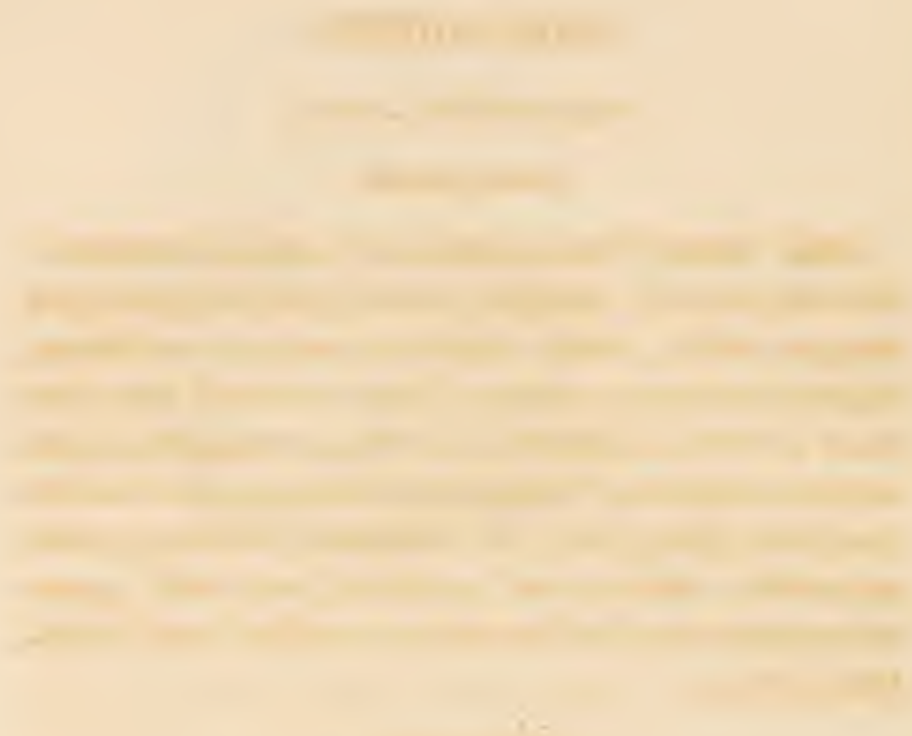




\section{UNIO POLITUS.}

\section{Plate XXXVII.-Fig. 2.}

\section{DESCRIPTION.}

Shell suborbicular, convex, with slight concentric furrows; anterior margin obtusely rounded; posterior margin nearly direct; ligament margin rectilinear, slightly declining; umbonial slope rounded; disks flattened or very indistinctly furrowed posteriorly; basal margin rounded, or slightly gibbous in the middle; epidermis glossy, with fine concentric wrinkles; umbo prominent, smooth and polished, with dark green interrupted rays; within white; cardinal teeth thick, very direct.

\section{SYNONYMES.}

U. politus, Say. Amer. Conch., No. 6.

U. subrotundus, Lea. Trans. Amer. Phil. Soc., new series, vol. iv. p. 117 , pl. xviii. fig. 45.

Cab.A. N. S. No. 20409.

\section{OBSERVATIONS.}

Related to $U$. Kirtlandicus, Lea, from which it differs in being proportionally more elevated and much less compressed. It is also a smaller species. The name of subrotundus has necessarily been abandoned, as it is preoccupied for a different species. 


\section{UNIO NEXUS.}

Plate XXXViII.-Fig. 1.

DESCRIPTION.

Shell triangular, sub-rhomboidal, much inflated, thick; umbo prominent; posterior slope much depressed, with a broad, shallow groove, which extends from the beak to the posterior margin; posterior margin forming nearly a right angle with the base, obtusely emarginate in the middle by the termination of the groove; umbonial slope carinated, in consequence of the depression of the posterior side; lunule very short; epidermis yellowish-brown, obsoletely radiated; within white; cardinal teeth direct; lateral teeth short, with but little obliquity.

\section{SYNONYMES.}

U. xexus, Say. 'Trans. Journ., vol. iv. p. 527, 1831. Amer. Conch., pl. li.

U. Arcrforyis, Lea. Trans. Amer. Phil. Soc., new series, vol. iv. p. 116, pl. xvii. fig. 44.

Cab. A. N. S. No. 20410.

\section{OBSERVATIONS.}

Mr. Say remarks that this species is "related to triqueter, Raf., but differs in the greater prominence of the superior portion of the anterior [posterior] margin." There is also a great difference in the teeth and in the markings of the epidermis, which in the nexus are filiform rays, but in the triqueter generally sagittate spots. Not uncommon in the Cumber- 


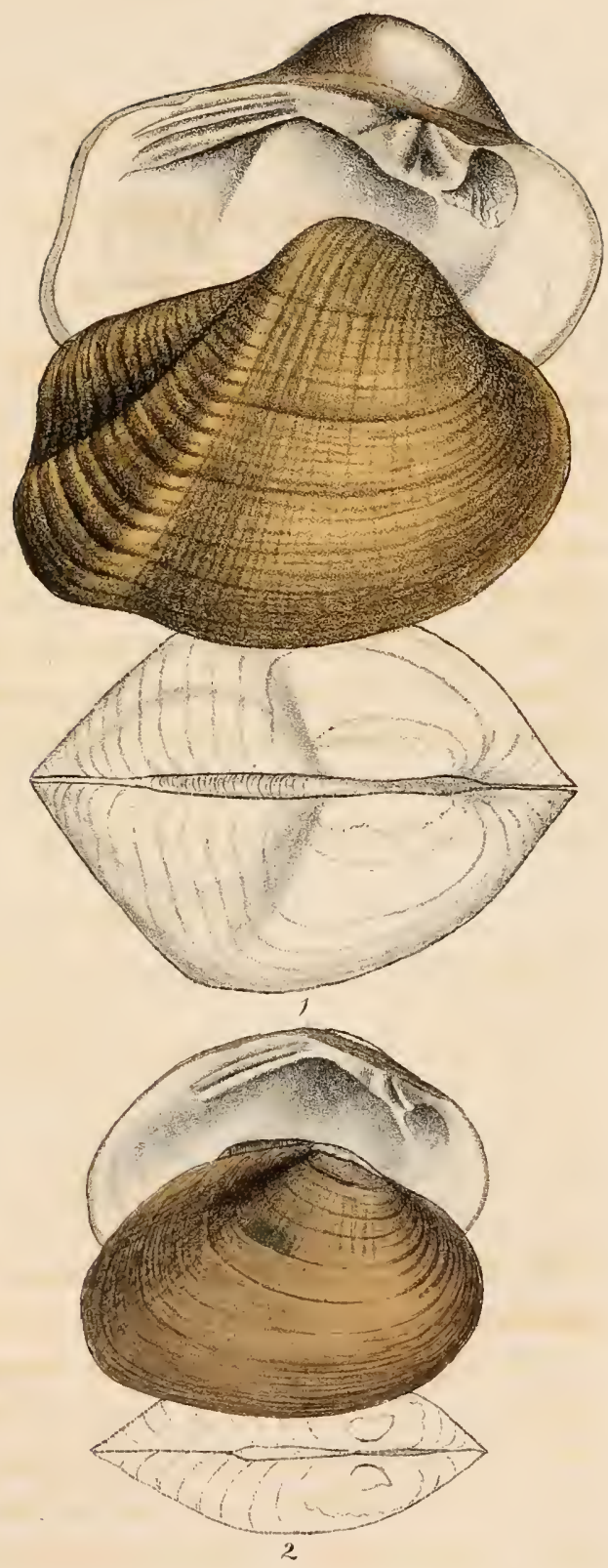

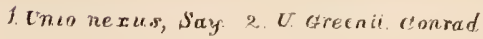




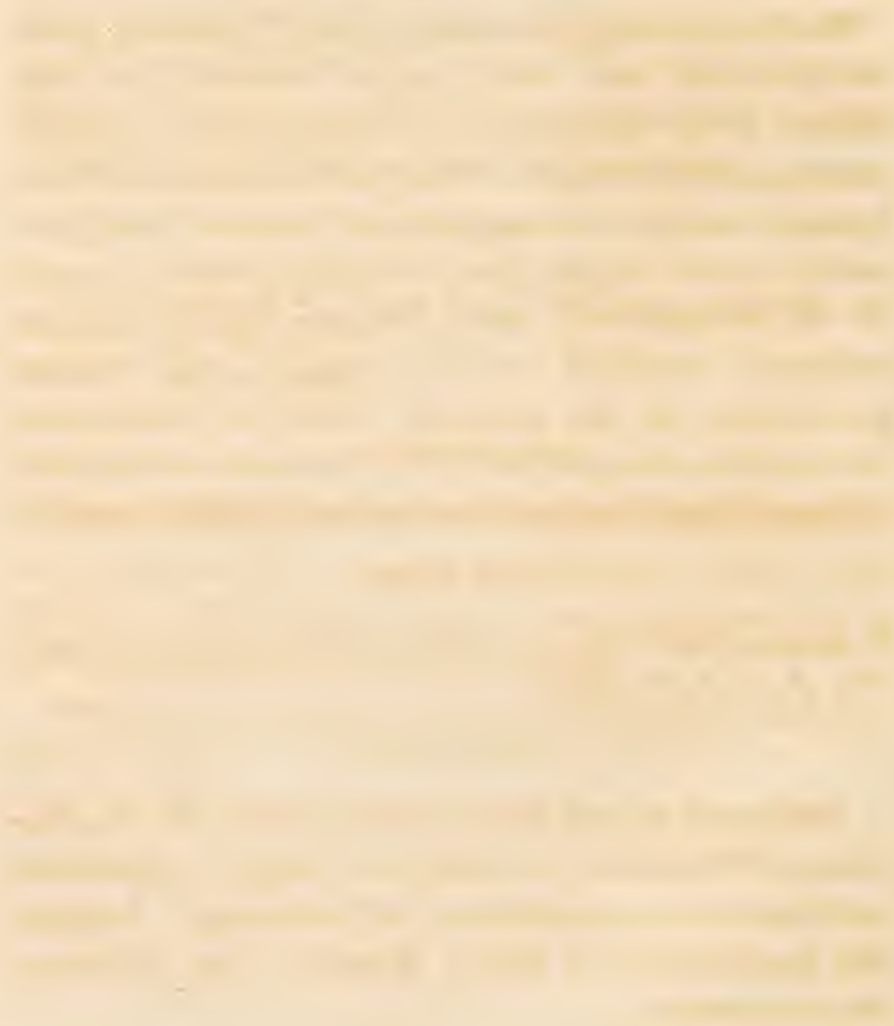


land river, and it seems chiefly confined to the waters of Tennessee-I saw none in Alabama. The figure is from a specimen in the cabinet of $\mathrm{Mr}$. Featherstonhaugh.

\section{UNIO GREENII.}

Plate XXXVIII.-Fig. 2.

DESCRIPTION.

Shell sub-triangular; disks slightly flattened; anterior side not very short, margin rounded, not very obtuse; umbo flattened, not elevated; beaks eroded; umbonial slope straight, subangulated; ligament short, ligament margin forming with the posterior margin a nearly regular arcuate line; extremity obtusely rounded or subtruncated; basal margin slightly arcuate; epidermis wrinkled on the margins, with narrow green rays on the posterior slope and interrupted rays on the umbo; within white; cardinal teeth slightly oblique; lateral teeth oblique and very slightly curved.

\section{SYNONYME.}

U. greenir, Nob. New Fresh Water Shells, p. 32, pl. iv. fig. 1. Cub. A. N. S. No. 2041 .

\section{OBSERVATIONS.}

Dedicated to my friend Jacob Green, M. D., Professor of Chemistry in Jefferson College, a gentleman well known as a contributor to Conchology. Inhabits the head waters of Black Warrior river, Alabama; not uncommon. 


\title{
UNIO SHEPARDIANUS.
}

\author{
Plate XXXIX. \\ DESCRIPTION.
}

Shell profoundly elongated, sinuous, compressed, tapering to the posterior extremity, which is truncated; valves rather thin, with concentric lines, profound over the umbonial slope, which is slightly elevated; a carinated line passes between the umbonial slope and posterior dorsal margin; beaks very small, hardly raised above the dorsal line; within purple; lateral teeth long and rectilinear, somewhat dilated or thickened near the anterior termination.

\section{SYNONYME.}

U. shepardianus, Lea. 'Trans. Amer. Phil. Soc., new series, vol. v. p. 95, pl. xiii. fig. 38 .

Cab. A. N. S. No. 20411.

\section{OBSERVATIONS.}

This is perhaps the most elongated, proportionally, of any known Unio, except the Grayanus, and differs chiefly in this respect from $U$. angustatus, which is the species most nearly related to it.

Inhabits Alatamaha river, near Hopeton and Darien, Georgia. 
39
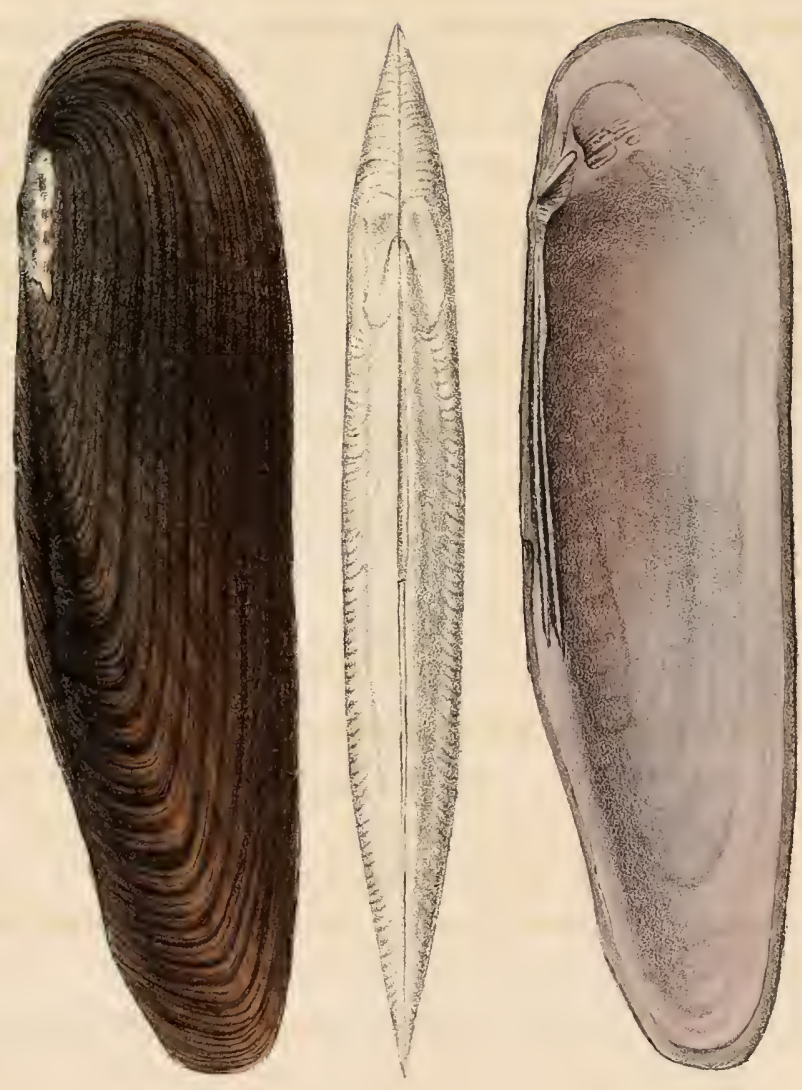

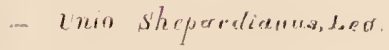




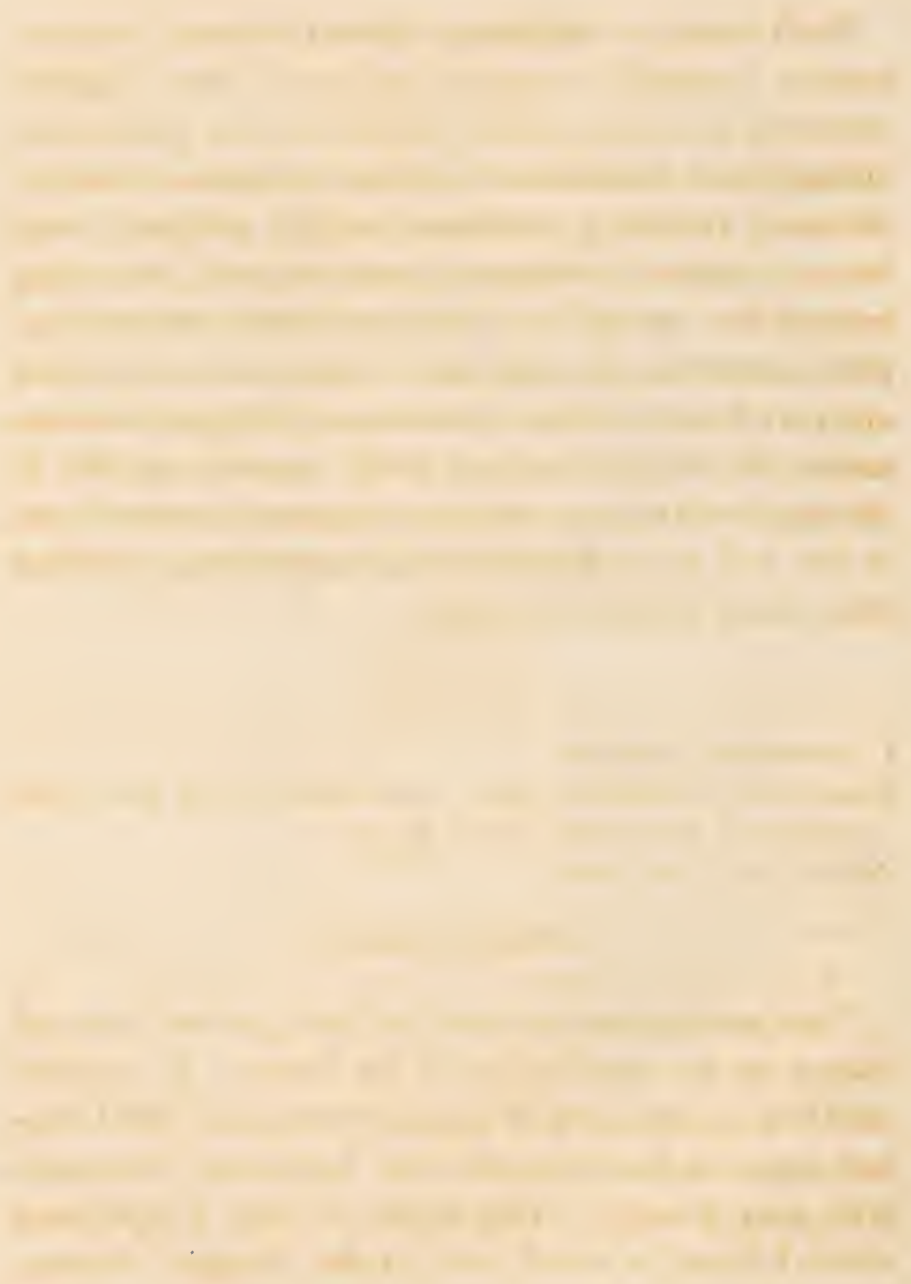




\title{
UNIO COMPRESSUS.
}

\author{
Plate XL.-Fig. 1.
}

DESCRIPTION.

Shell oblong or elliptical; disks flattened; anterior margin regularly rounded; umbonial slope slightly elevated, rounded; beaks undulated, not prominent, distant from the anterior extremity; ligament margin elevated, connate; posterior margin oblique, rectilinear, extremity truncated and slightly projecting beyond the line of the base; epidermis ochraceous, with numerous unequal green rays, some of which are very broad; within white, tinged with pale salmon under the beaks; cardinal tooth scarcely double in the right valve, very oblique, elongated, rather thick; in the left valve widely trifid, compressed, posterior lobe rather behind the apex.

\section{SYNONYMES.}

U. compressus, Deshayes.

Symphynota compressa, Lea. 'Trans. Amer. Phil. Soc., (new series, ) vol. iii. p. 450 , pl. xii. fig. 22.

Cab. A. N. S. No. 1098.

\section{OBSERVATIONS.}

This species can at once be distinguished from all others by the peculiarity of its hinge. It inhabits the Ohio, Scioto, and Wabash rivers; also Oak Orchard creek, in the State of New York, and Norman's Kill, near Albany. The figure is from a specimen which I found in a mill pond at the village of Adams, 
Jefferson county, New York, where the species is extremely abundant.

\section{UNIO CAPSFFORMIS.}

Plate XL.-Fig. 2.

DESCRIPTION,

Shell sub-oval, slightly ventricose, moderately thick; posterior side flattened or very slightly grooved; umbonial slope obtusely angulated; basal margin rounded medially, straight or slightly emarginate posteriorly; posterior extremity direct, truncated, narrowed, slightly produced; summits obtusely rounded, not prominent; epidermis yellowish, with numerous narrow unequal green rays; within white; cardinal teeth very erect and prominent.

\section{SYNONYME.}

U. capsefformis, Lea. Trans. Amer. Philos. Soc., new series, vol. iv. p. 145, pl. ii. fig. 4.

Cab. A. N. S. No. 20414.

OBSERVATIONS.

Inhabits Cumberland river near Nashville, Tennessee. I have found it in the Tennessee river at Florence, Alabama. It bears a slight resemblance to the young of $\boldsymbol{U}$.flexuosus, and is a very distinct species. The female is represented in figure 3. Between the sexes the difference in outline is greater than in any species with which we are acquainted, except $\boldsymbol{U}$. gibbosus, Raf. 

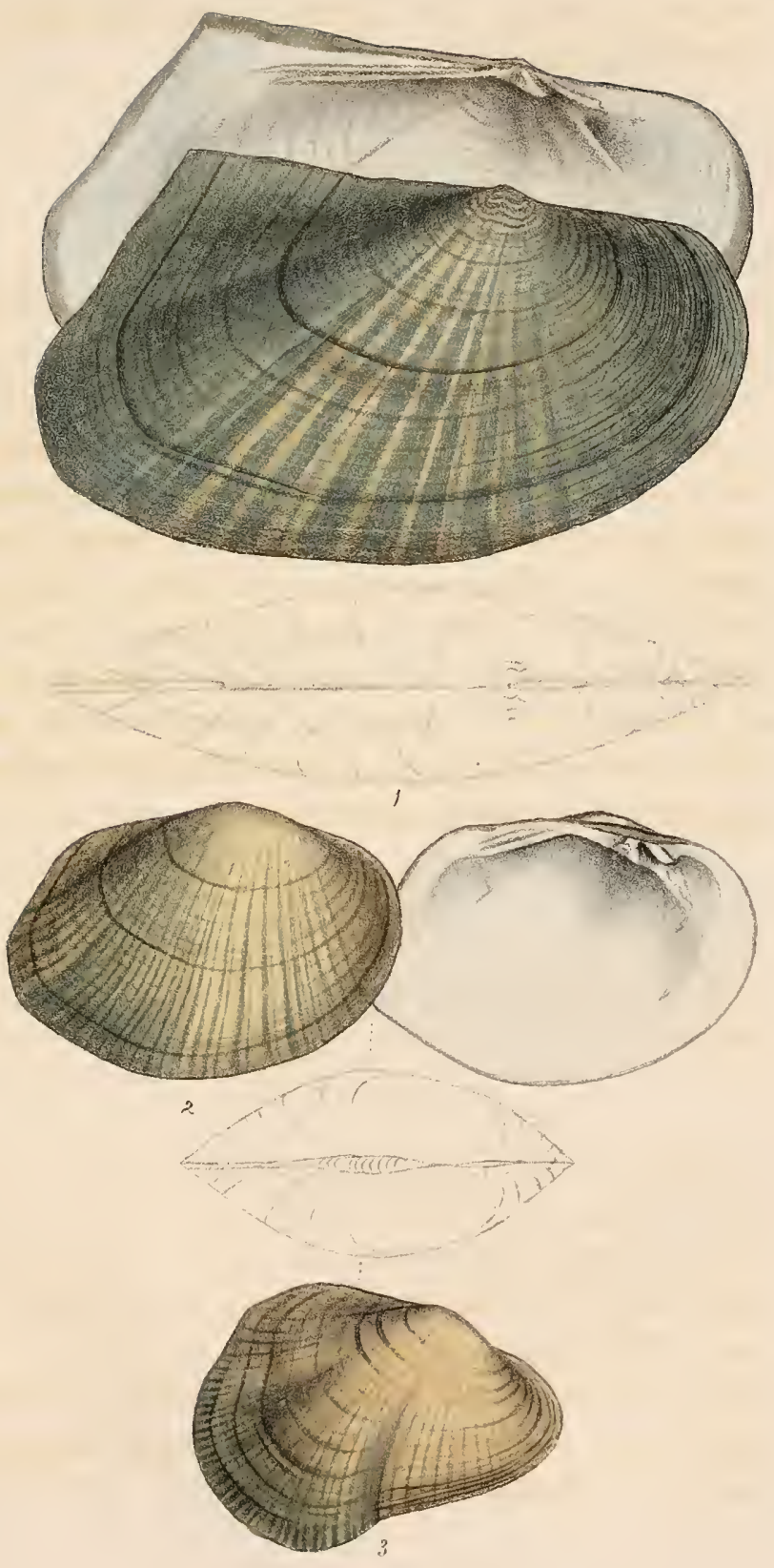

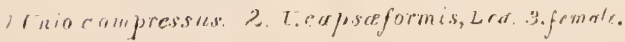





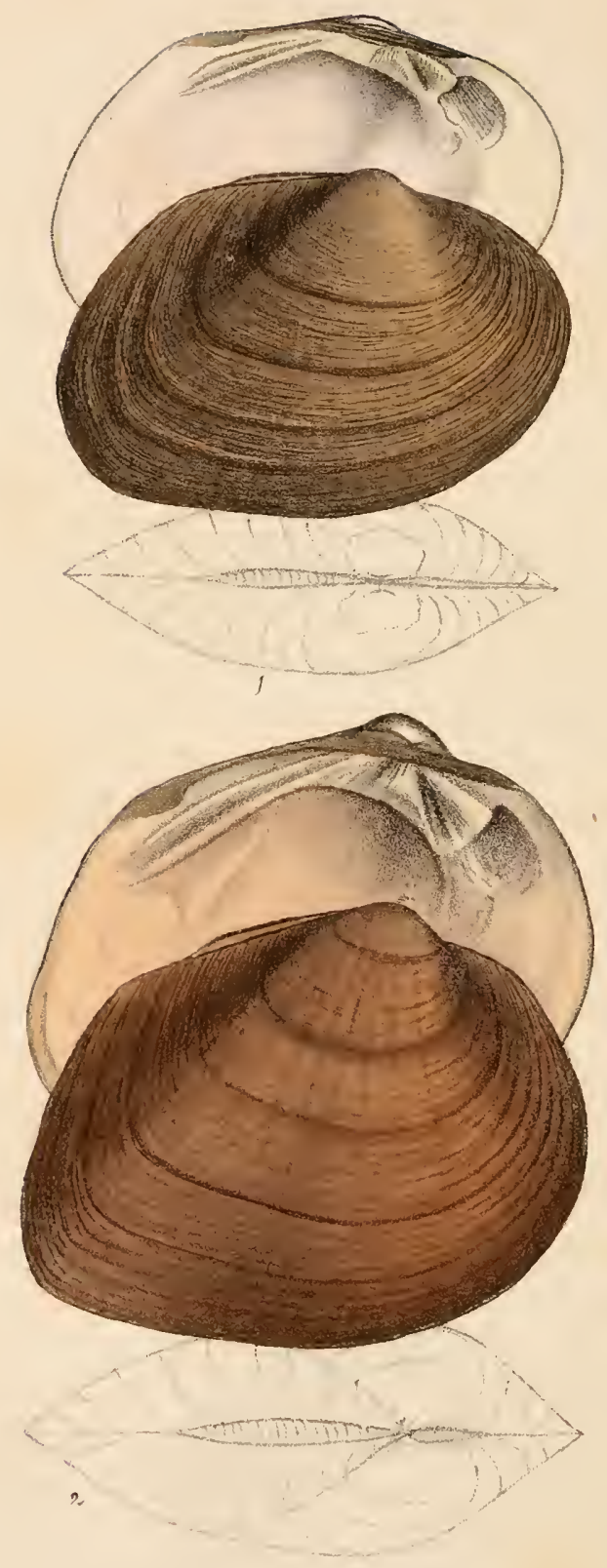

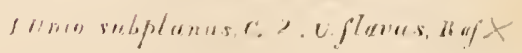


The two fine specimens figured belong to the splendid collection of Mr. Poulson. They were sent from Nashville, Tennessee.

\section{UNIO SUBPLANUS.}

Plate XLI.-Fig. 1.

DESCRIPTION.

Shell sub-oval; disks flattened; anterior margin regularly rounded, obliquely descending; umbonial slope rounded; posterior slope dilated; beaks not prominent, distant from the anterior extremity; ligament margin elevated, slightly oblique; posterior extremity truncated; epidermis yellowish-brown, with numerous fine concentric wrinkled lines; within pale rose colour; cardinal teeth oblique; lateral teeth rectilinear.

Cab.A. N. S. No. 20412.

OBSERVATIONS.

I have recently received several specimens of this shell from Lexington, Rockbridge county, Virginia, where they were found by Mr. Newkirk in a branch of the James river. Approaches $\boldsymbol{U}$. Masoni, but is more compressed and elongated, and cannot be confounded with it. 


\section{UNIO FLAVUS.}

Plate XLI.-Fig. 2.

DESCRIPTION.

Shell sub-triangular, moderately thick; disks flattened on the posterior side; anterior margin obtusely rounded; ligament margin oblique, rectilinear; posterior margin wide, straight, nearly direct; extremity obtuse; basal margin straight from the posterior extremity to beyond the middle; umbonial slope carinated; umbo rather prominent; beaks flattened, with a few obtuse oblique undulations; within salmon colour; cardinal and lateral teeth large and very prominent.

\section{SYNONYMES.}

U. Frava, $R f$. Aun. gen. des Sc., vol. v. p. 59. Poulson's trans., p. 38.

U. rubiginosus, Lea. Trans. Amer. Phil. Soc., new series, vol. iii. p. 41, pl. viii. fig. 10 .

Cab. A. N. S. No. 1126.

\section{OBSERVATIONS.}

This shell is so distinctly described and even figured by Rafinesque, that no honest inquirer can refuse him credit for the species. He remarks that he found "it only in the small rivers falling into the Kentucky, Salt or Green rivers." This peculiarity of habitat is remarkable, and I was unable to find a specimen in either the Alabama, Tombeckbe, or Black Warrior rivers, although several were found in a small mill stream in Greene county, Alabama. Rafinesque re- 



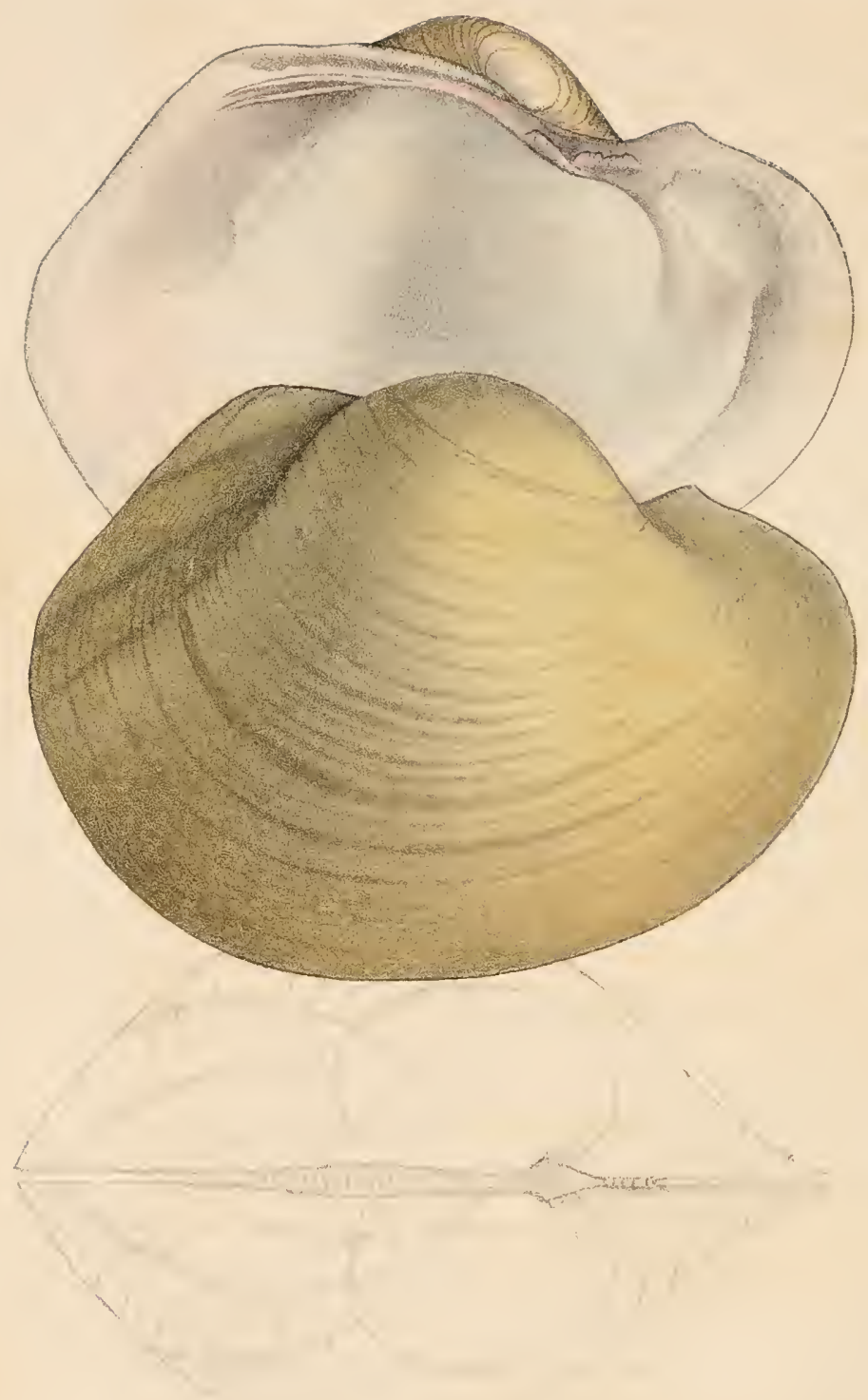

Uruen respast rovers. 
marks that the "young shells are almost yellow, and the animal of a deep or orange-yellow colour," which accords with my own observation. I do not, however, consider the colour of the animal any safe guide in specific distinction, as I have found the same species, particularly $\boldsymbol{U}$. decisus, to contain in some specimens an orange coloured, and in others a perfectly white animal.

\section{UNIO CAPAX.}

\section{Plate XLII.}

DESCRIPTION.

Shell very globose; valves rather thin, translucent, connate; umbones tumid, summit obtusely rounded, prominent, distant from the anterior margin; epidermis straw colour, polished, with two faint green rays on the posterior slope; within white and iridescent; cardinal teeth lamellar, prominent, double in the right valve, crenate and single in the left; lateral teeth arcuate.

\section{SYNONYMES.}

U. capax, Green. Cab. of Nat. Hist., vol. ii. p. 290. 1832.

Symphynota globosa, Lea. 'Trans. Amer. Phil. Soc., new series, vol. iv. p. 153, pl. iv. fig. 12. 1834.

Cab. A. N. S. No. 122\%.

OBSERVATIONS.

The most ventricose of all the Unios known, and, when young, one of the most delicate and beautiful. 
distiuctir

It most nearly resembles $U$. cardium, Raf., but the tumid umbones will always prove a diftrytutive character. Dr. Green was the first to recognise this as an undescribed species, and his name, having priority, must necessarily be adopted. He observes, "I now describe a fine large shell, which seems to luave escaped the notice of our conchologists. The first specimens of this shell which I observed were from the Falls of St. Anthony. I afterwards received it from the Bayou Teche, but I never discovered or ascertained that it exists in the Ohio." Mr. Lea, on the authority of Col. Long, informs us that it inhabits the Ohio, 150 miles below Louisville, $\mathbf{K y}$.

\section{UNIO RUDIS.}

Plate XliII.-Fig. 1.

DESCRIPTION.

Shell ovate-acute, thick anteriorly; diameter greatest at the umbones; beaks eroded; posterior side cuneiform; ligament and posterior margins arcuate, extremity subangulated; epidermis brown, wrinkled inferiorly; within white; cardinal teeth small, direct; lateral teeth slightly arcuate.

\section{SYNONYME.}

U. ravenelianus, Lea. 'Trans. Amer. Phil. Soc., ncw series, vol. iv. p. 144, pl. iii. fig. 5.

Cul. A. N. S. No. 20415.

OBSERVATIONS.

Inhabits French Broad river, North Carolina, Dr. 


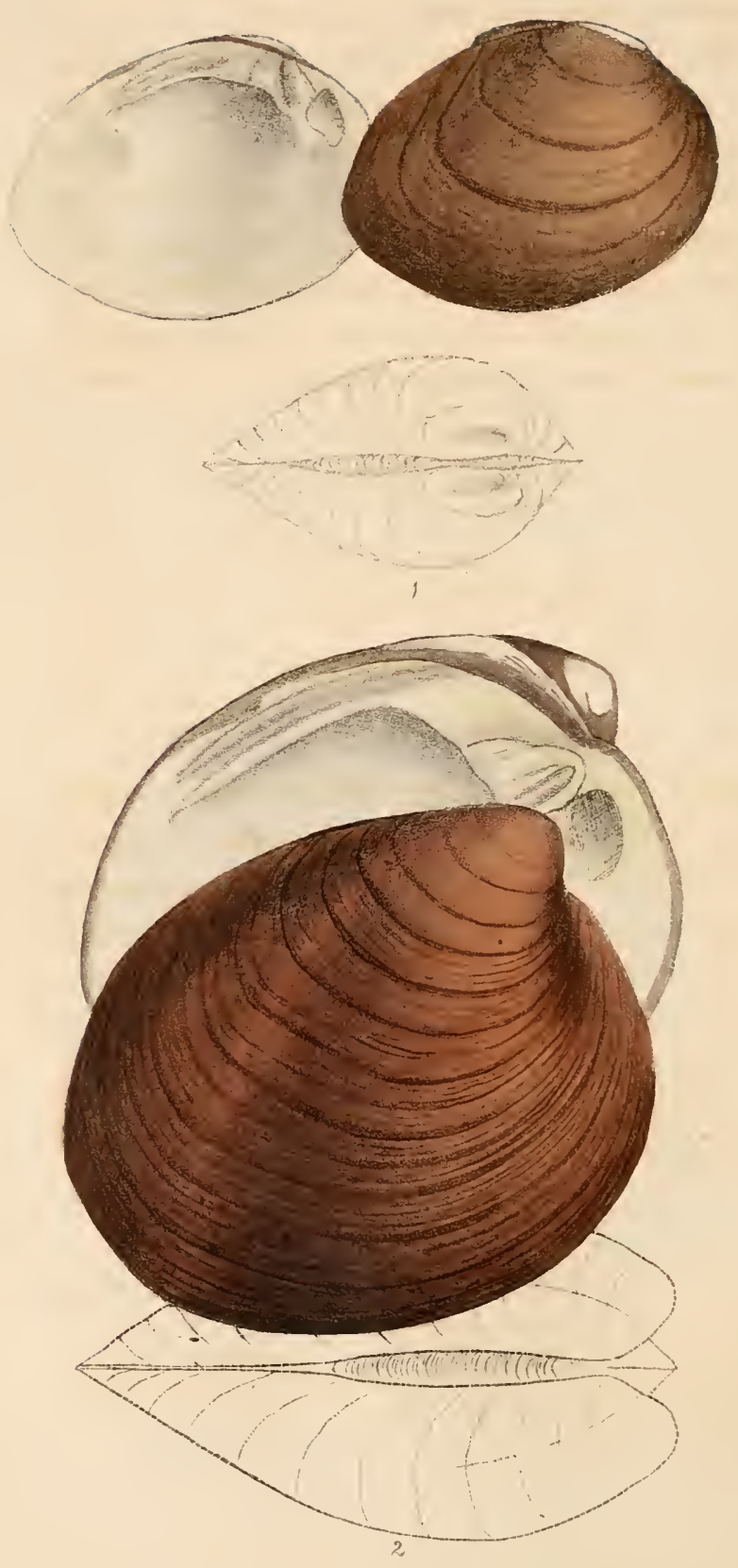

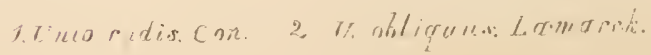


Ravenel. I found it in the upper part of the Black Warrior river, Alabama, where it is rare.

Resembles $U$. perovatus in outline, but the shell is far greater in diameter through the umbones, and the beaks nearer the anterior extremity. The most striking character, perhaps, is the accurate wedgeshaped form of the posterior side. Mr. Lea first published this species under the name of Ravenelianus, but as I had previously published a different species with the same name, I am compelled to substitute another.

\section{UNIO OBLIQUUS.}

Plate XliII.-Fig. 2.

DESCRIPTION.

Shell ovate-rotundate, oblique; disks with a slight narrow furrow on the posterior side; umbonial slope carinated; posterior slope with an obtuse carinated line; ligament and posterior margins arcuate; posterior extremity obliquely truncated; beaks very prominent, curving forward; lunule sagittate; within white; cardinal teeth directed obliquely backwards; lateral teeth arcuate; cardinal plate much thickened under the cardinal teeth, contracting the cavity of the umbo.

SYNONYMES.

U. obliqua, Lam. An. sans Vert., vol. vi. p. 72. Ferus. Mag. de Zool.

U. ebenus, Lea. Trans. Amer. Phil. Soc., new scries, vol. iii. p. 94, pl. ix. fig. 14. Cab. A. N. S. No. 1259. 
OBSERVATIONS.

Inhabits the Black Warrior and Alabama rivers, where I found it in abundance; also the Ohio and its tributaries.

The ovate form of this species and its obliquity will distinguish it at a glance from undatus, Barnes. The young is remarkable for being of yellow colour behind the umbonial slope, which soon disappears in general as the shell increases in size.

Mr. Lea appears to be ignorant of the true distinctive character of this species, since he affirms that I have published it under the name of mytiloides; the latter is destitute of the callosity of the cardinal plate which characterizes the obliguus, has a very different lunule, and is dissimilar in outline to that species. Those who are conversant with the two shells will not confound them.

Mr. Lea considers the obliqua of Lamarck to be identical with undatus of Barnes, but Lamarck's description is wholly inapplicable to the latter, whilst it agrees with the ebonus of Lea, with which it is identical, according to Ferussac.

\section{UNIO APICULATUS.}

Plate XLIV.-Fig. 1.

DESCRIPTION.

Shell subquadrate, compressed; summits not very prominent; hinge margin declining; disks with a dilated not deeply impressed furrow; umbonial slope 

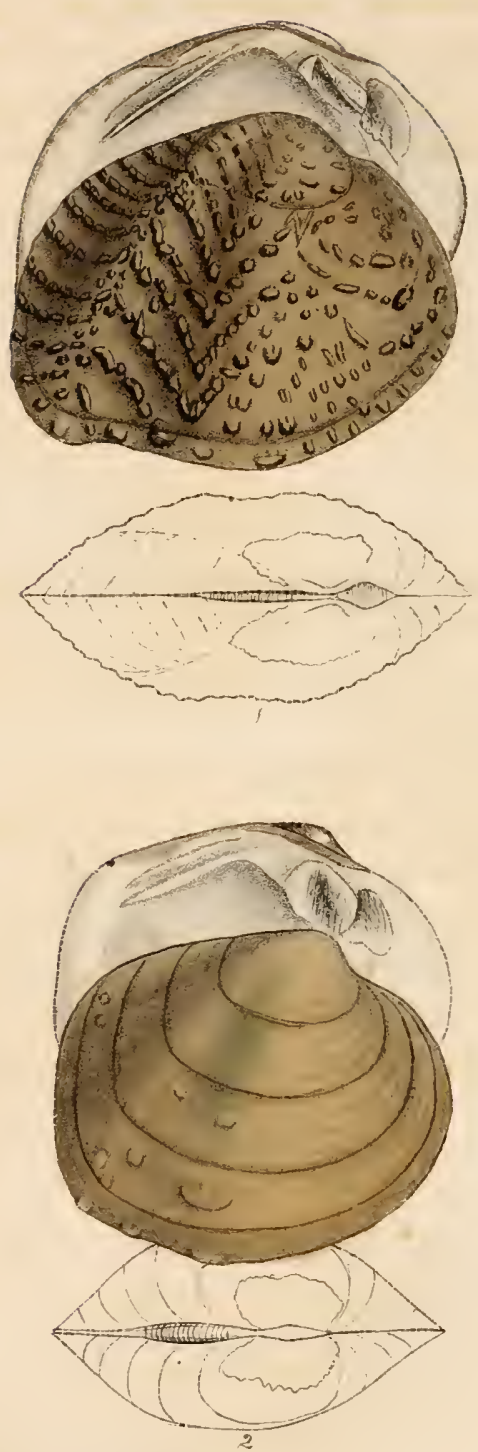

1. Une apreulatu.s, say. 2.1 prasimus, can. 
arcuate, carinated; posterior margin dilated, direct, produced, and rounded or subtruncated at base; disks covered with small subequal tubercles, arranged more or less in symmetrical lines; within white.

SYNONYMES.

U. apiculatus, Say. Disseminator, 1829. American Conch. pl. 52.

U. Asper, Lea. Trans. Amer. Phil. Soc., new series, vol. iii. p. 95, pl. ix. fig. 15, 1832.

Cab. A. N. S. No. 1877.

OBSERVATIONS.

Inhabits the Alabama river, near Claiborne, where I found specimens, but they were not numerous nor comparable in beauty to those which inhabit Bayou Teche in Louisiana.

Mr. Say thinks this may prove to be a variety of $U$. quadrulus, but although it is nearly related to that species we believe it to be very distinct. Old shells become proportionally more elongated and produced at the posterior extremity of the basal margin, and the tubercles nearly disappear on the inferior half of the disks. The figure is from a specimen from Bayou Teche.

\section{UNIO PRASINUS.}

Plate XLIV.--Fig. ¿.

DESCRIPTION.

Shell suborbicular, compressed, with distant concentric impressed lines; anterior margin obtusely 
rounded; posterior margin wide, direct; basal margin straiglit, parallel with the ligament margin; summits rather prominent; disks smooth, with a few very small tubercles on the posterior side; epidermis oliveyellow, very broadly rayed with green; within white.

\section{SYNONYMES.}

U. prasinus, Nob. New Fresh Water Shells, p. 44. May, 1834.

U. sciroolcraftersis, Lea. 'Trans. Amer. Phil. Soc., new series, vol. iv. p. 149, pl. iii. fig. 9. Sept. 1834.

Cab. A. N. S. No. 1128.

\section{OBSERVATIONS.}

Inhabits the Scioto river, Indiana.

The specimen of this shell in the cabinet of the Academy of Natural Sciences was brouglit by Mr. Schoolcraft from Fox river, of Green Bay-others are in the collection of Mr. Hyde. The species differs from $\boldsymbol{U}$.bullatus, Raf., in being of a suborbicular outline, more compressed, with much less prominent beaks and fewer tubercles. Some specimens have a few rather large tubercles near the base.

\section{UNIO NODULATUS.}

\section{Plate XlV.--Fig. 1.}

DESCRIPTION.

Shell suborbicular, slightly ventricose, moderately thick; posterior margin direct, retuse in the middle; ligament margin straight, elevated, scarcely declining; disks with two series of distant prominent tubercles; 

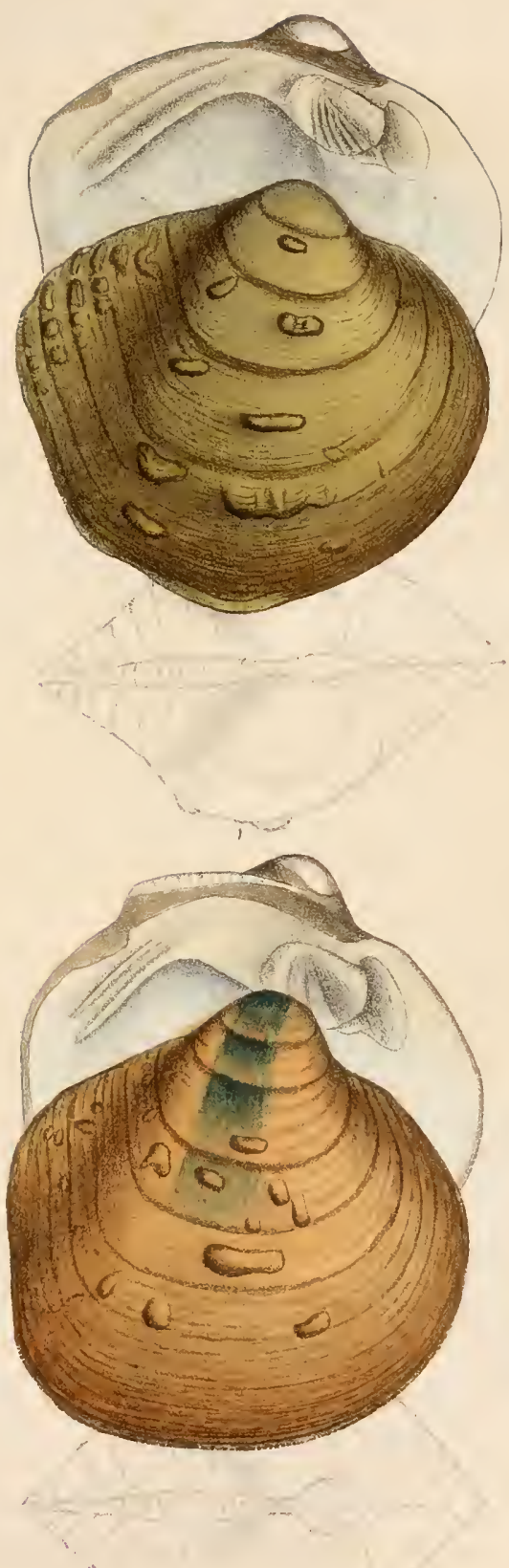

posterior slope dilated, with nodules towards the margin; beaks slightly elevated, granulate at tip; epidermis olive-brown and rather smooth; within white; cardinal teeth large and prominent; lateral teeth subrectilinear.

\section{SYNONYMES.}

U. Nodulata, Raf. Ann. gen. des Sc. Phys., vol.v. p. 41, pl. lxxxi. figs. 17, 18. Poulson's translation, p. 42. Say. Amer. Conch., No.6. Ferrus. Mag. de Zool.

U. pustulatus, Lea. Trans. Amer. Phil. Soc., new series, vol. iv. p. 79, pl. vii. fig. 9 .

Cab. A. N. S., No. 1755 .

\section{OBSERVATIONS.}

Inhabits the Ohio river and its tributaries. It is related to $\boldsymbol{U}$. bullatus and $\boldsymbol{U}$. Mortoni. From the former it differs in the regularity of its tubercles, in the dilatation of the posterior slope, and in the absence of the broad green ray on the umbo. From the latter it may be distinguished by the same characters, and, in addition, by the want of a broad depression or furrow, which characterizes $U$. Mortoni. Rafinesque's outlines of this shell, though rude, are characteristic enough; and his description, though short, perfectly clear and applicable to this species only. 


\section{UNIO BULLATUS.}

\section{Plate Xliv.-Fig. 2.}

\section{DESCRIPTION.}

Shell elevated, equilateral, inflated, irregularly tuberculated on the middle and posterior slope; medial tubercles generally large; substance of the shell thick; beaks elevated and granulated at tip; ligament slope descending, short; posterior margin direct, nearly straight; epidermis bright brown, a single broad interrupted green ray passes from the apex to the middle of the disk; within white; lateral teeth very short, straight, thick and oblique.

SYNONYMES.

U. bullata, Raf. Ann. gen. des Sc. Pliys., vol.v.p. 41. Poulson's trans., p. 43.

U. verrucosus albus, Hill. Silliman's Journ., vol. xiv. p. 289.

U. pustulosus, Lea. 'Trans. Amer. Phil. Soc., new series, vol. iv. p. 76 , pl. vii. fig. 7 .

Cab. A. N. S., No. 1175 .

OBSERVATIONS.

Inhabits the Ohio and its tributaries, Alabama and Black Warrior rivers. This common species is easily recognised, and will be found to differ constantly from $U$. prasinus by its more elevated and ventricose form and more numerous tubercles. It wants the furrow of the Mortoni, and is besides distinguished by its green ray and larger tubercles. The white colour of the nacre is remarkably constant, 
as I have never found it to vary in a great number of specimens, which is seldom the case in most other species. A variety is remarkably abundant in the Black Warrior river, at Erie, Alabama.

Mr. Say has referred this species to $U$. nodulosus, Wood, but the figure of that shell in Wood's Conchology appears to me to represent a very different species.

\section{UNIO STEGARIUS.}

\section{Piate XIVVI,-Fig. 1.}

DESCRIPTION.

Shell elevated, ovate; valves thick, with concentric furrows and ridges; disk with a narrow, not deeply impressed furrow from beak to base; umbo and beaks inclining forward; lunule large, ovate-acute, very distinct; beaks pointed and incurved; umbonial slope carinated over the umbo; epidermis yellowish-brown, with crowded, fine, green dotted rays, and broad rays, composed of large dots; posterior margin direct; within white; cardinal plate greatly dilated; cardinal teeth direct, deeply sulcated; muscular impressions small.

\section{SYNONYMES.}

U. stegaria, Raf. Ann. gen. des Sc. Phys., vol. v. p. 46. Poulson's translation, p. 51. Say, Amer. Conch., No. 6. Ferr., Mag. de Zool.

U. irroratus, Lea. Trans. Amer. Phil. Soc, new series, vol. iii. p. 269 , pl. v. fig. 5 . Cab. A. N. S., No. 1122. 
OBSERVATIONS.

Inhabits the Ohio, Scioto, Wabash, and more rarely the rivers of Tennessee. I have not observed it so far south as the Tennessee river, in Alabama. It is a very beautiful species, remarkable for its very numerous dotted rays and its regular and graceful outline, which approaches that of $\boldsymbol{U}$. retusus.

\section{UNIO DROMAS.}

Plate XlVi.-Fig. 2.

\section{DESCRIPTION.}

Shell obliquely ovate; disks flattened above, and with a very prominent concentric angular ridge in the middle; a slight furrow from beak to base on the posterior side; beaks prominent, summit rather wide, flattened; lunule angular; epidermis yellowish-brown, with very numerous green interrupted capillary rays, and a few broad rays; within white; cavity shallow.

\section{SYNONYME.}

U. promas, Lea. Trans. Amer. Phil. Soc., new series, vol. v. p. 182, pl.x. fig. 29.

Cab. A. N. S., No. 20416.

\section{OBSERVATIONS.}

Inhabits Harpeth and Cumberland rivers, Tennessee; Elk river, near the muscle shoals, Alabama. I have not found it further south.

My father, many years since, received this elegant 


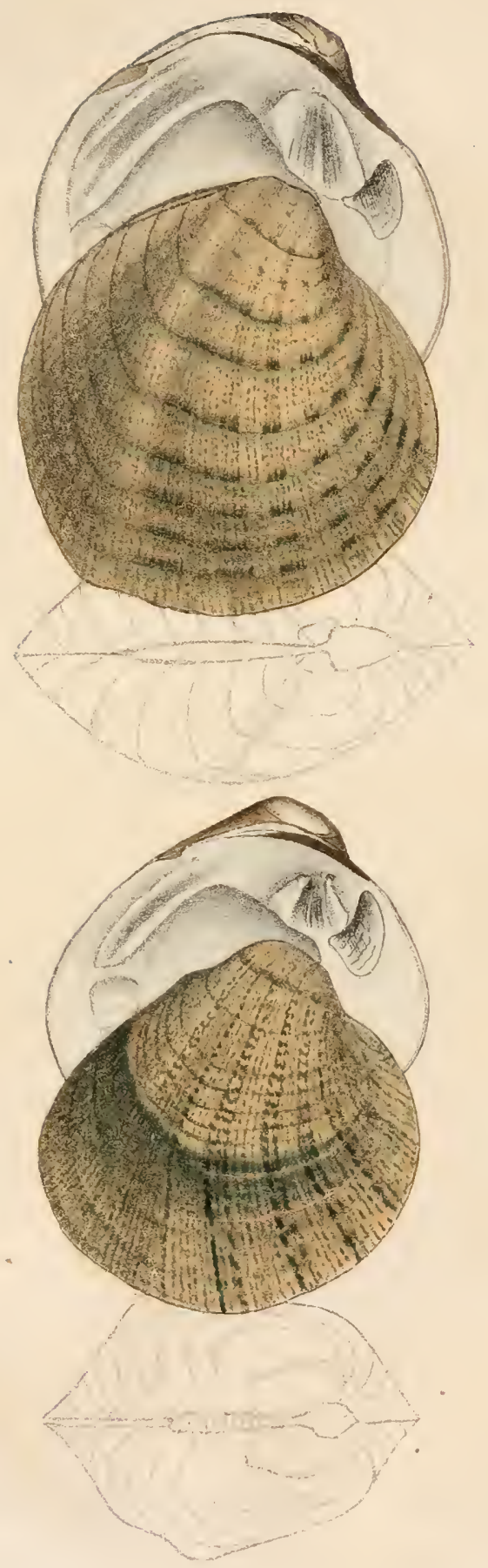



species from Harpeth river, Tennessee. It cannot be confounded with $\boldsymbol{U}$. stegarius, in consequence of its remarkable gibbose disk. The rays are more strongly marked than those of the latter species; the disk is never tuberculated, whilst the stegarius is sometimes covered with tubercles, as Mr. Lea has stated in his remarks upon the dromas. A single valve in my cabinet measures about four inches from beak to base.

\title{
UNIO SUBTENTUS.
}

\author{
Plate XI.VII.-Fig. 1.
}

DESCRIPTION.

Shell oblong-suboval, very widely and slightly contracted at base; summits hardly elevated, decorticated, obtusely rounded; posterior basal angle a little prominent, rounded; posterior dorsal slope with numerous subramose, slightly arcuate, oblique, parallel costæ; epidermis with broad interrupted green rays, sometimes obsolete; within reddish-fulvous; cavity of the umbo not deep; cardinal teeth somewhat direct, not transverse; lateral teeth slightly arcuate.

SYNONYME.

U. subtentus, Say. Jour. Acad. Nat. Sc., vol. v. p. 130. Amer. Conch., pl. xv.

Cab. .A. N. S., No. 20417.

OBSERVATIONS.

Mr. Say observes, "in general outline, this shell 
has some resemblance to $U$. purpurcus, Nob.; but it is distinguished by many characters, and more obviously by the character of the anterior costated margin. It is a native of South Carolina, ${ }^{*}$ and was sent to me by Professor Vanuxem, who obtained it from the North Fork of the Holston river."

Dr. William Blanding presented me with specimens from Nollichucky river, Tennessee, the largest of which is nearly destitute of the posterior ribs. I found a few dead shells on the bank of Elk river, near the muscle shoals, Alabama.

\section{UNIO ACUTISSIMUS.}

Plate XLVII.-Fig. 2.

DESCRIPTION.

Shell narrow-elliptical; posterior side produced, gradually narrowed to a point; valves thin; posterior side with parallel furrows extending from the umbonial slope to base; posterior slope with slightly arcuate ribs and furrows; umbonial slope carinated; beaks not elevated above the dorsal line; epidermis yellowish, with green dotted rays; within yellowish, highly polished, exhibiting the ribs of the exterior.

SYNONYME.

U. acutissimus, Lea. Trans. Amer. Phil. Soc., new series, vol. iv. p. $89, \mathrm{pl}$. x. fig. 18 .

Cab. A. N. S., No. 20418.

* Mr. Vanuxem informs me that he found it in Virginia. 


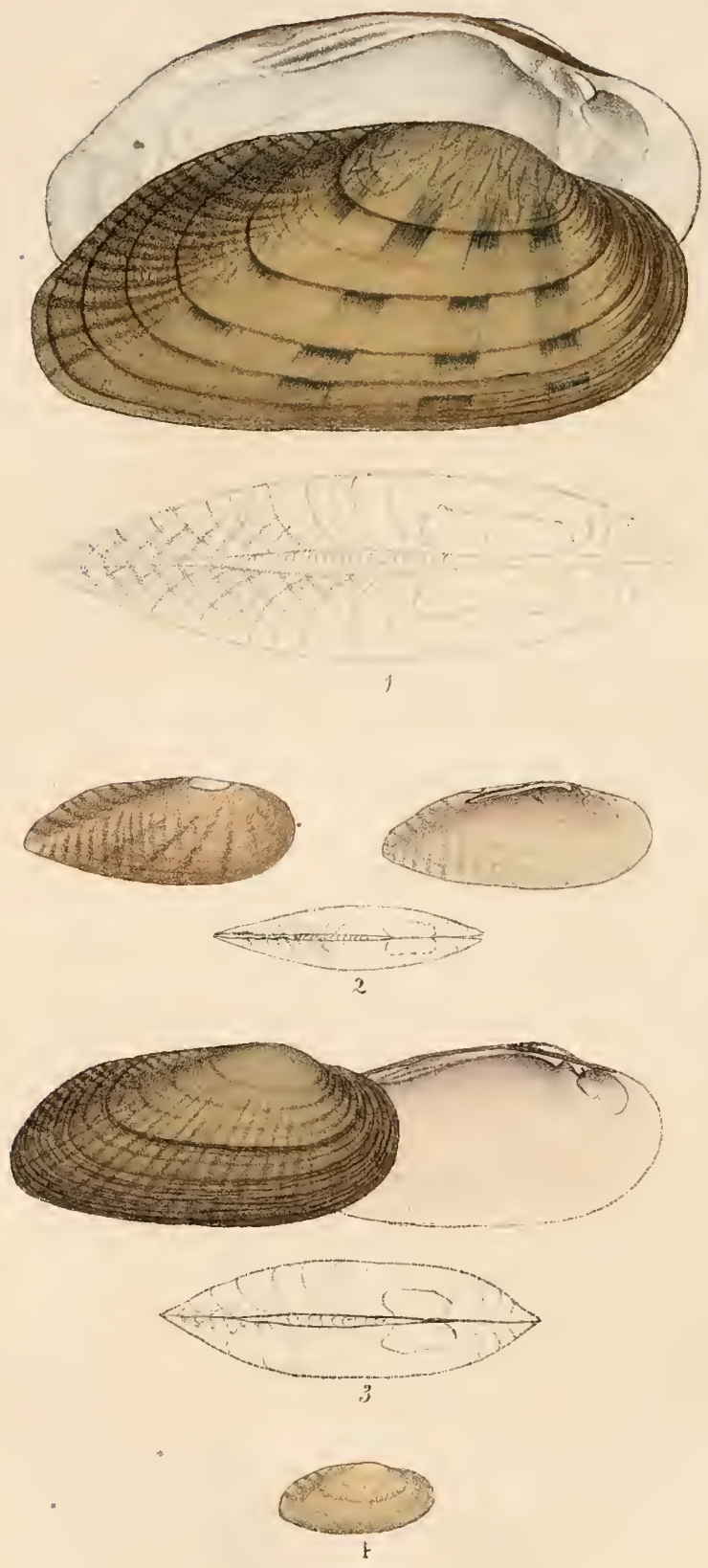

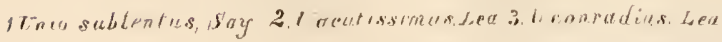


Inhabits the Alabama and Black Warrior rivers: rare.

This is one of the smallest species of Unio, and resembles the young of the conradius, but is much more elongated. Mr. Lea observes that the lateral teeth are single in each valve; but the specimens before me have the usual form of a divided tooth in the left valve. The epidermis is marked with pale green zig-zag lines, and the furrows on the disk are sometimes obsolete or wanting. I found two fine individuals at the village of Erie, Greene county, Alabama, on a bar in the Black Warrior river.

\section{UNIO CONRADIUS.}

\section{Plate XLVII.-Fig. 3.}

DESCRIPTION.

Shell elliptical, basal margin straight or slightly emarginate; ligament margin slightly declining; valves rather thin, with undulations on the posterior side, sometimes obsolete; posterior slope with arcuate ribs; beaks very slightly prominent and undulated, decorticated; epidermis finely wrinkled, yellowishbrown, with numerous green rays; within inclining to salmon colour; very iridescent and furrowed posteriorly.

\section{SYNONYME.}

U. conradius, Lea. Trans. Amer. Phil. Soc., new series, vol.v. p. 63 , pl. ix. fig. 23.

Cab. A. N. S., No. 20419. 
OBSERVATIONS.

Inhabits Flint river, Alabama, near its junction with the Tennessee river, and is common in the vicinity of Nashville, Tennessee. This small species is related to $U$. subtentus, but is very obviously distinct. It is proportionally shorter than the acutissimus, and has more obvious beaks, but young individuals much resemble the latter species, as may be observed in fig. 4. In some specimens the posterior undulations are large and profound, in others more numerous and not so distinct.

\section{UNIO INTERRUPTUS.}

\section{Plate XLVIII.}

\section{DESCRIPTION.}

Shell subtriangular, disks flattened; umbones broad, flattened, summits obtusely rounded; posterior slope much depressed; umbonial slope abruptly rounded, nearly terminal; epidermis brownish-yellow, wrinkled, except on the umbo; rays numerous, narrow, interrupted, of a dark olive colour; on the umbonial and posterior slopes consisting of series of small quadrangular spots; within white; cardinal and lateral teeth very robust; anterior and posterior muscular impressions deeply impressed.

\section{SYNONYMES}

U. interrupta, Ruf. Ann. gen. des Sc. Phys., vol. v. p. 36. Say. Amer. Conch., No. 6. Ferr. Mag. de Zool.

U. brevidens, Lea. Trans. Amer. Phil. Soc., new series, vol. iv. p. 75 , pl. vi. fig. 6 .

Cab. A. N. S., No. 1114. 

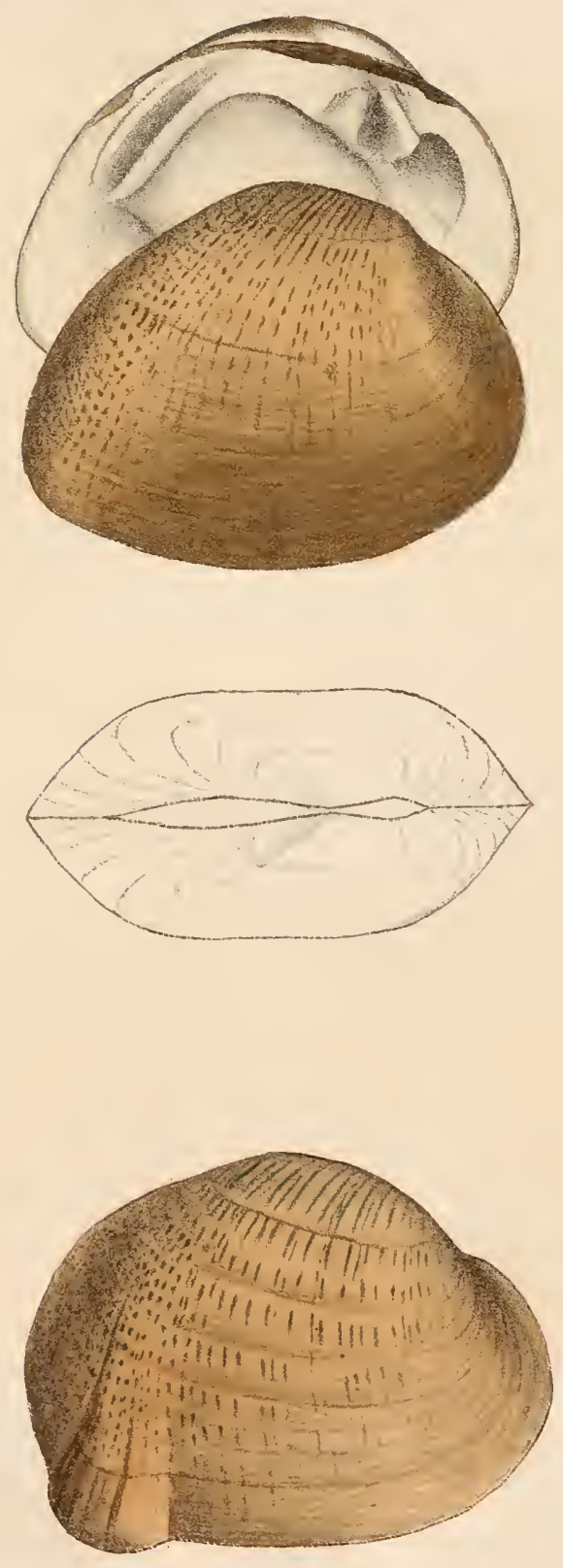

L interruptus, Rafinesure. 



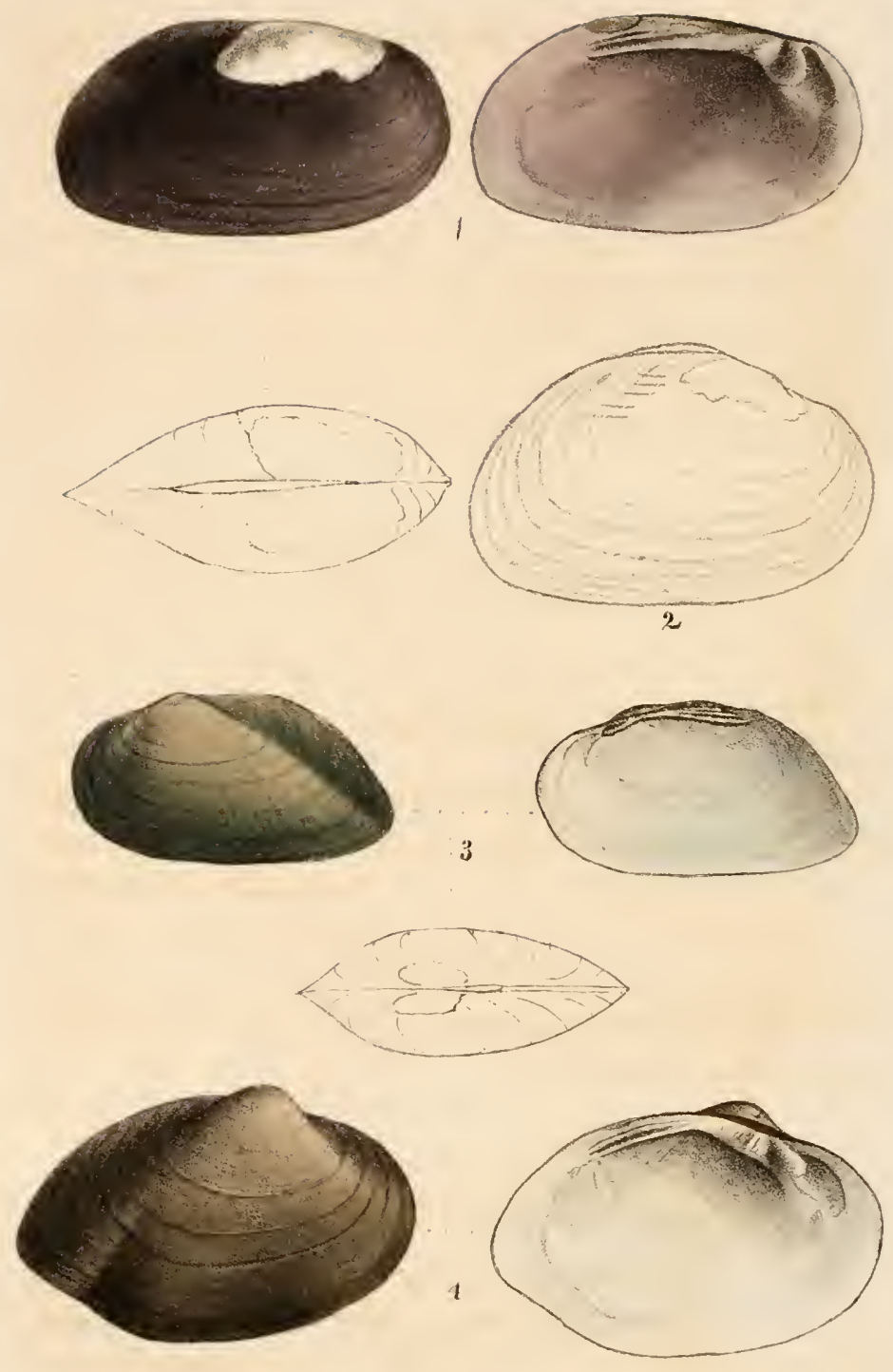

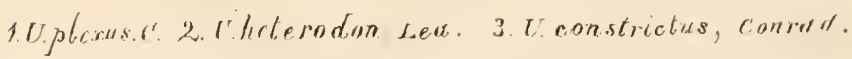


OBSERVATIONS.

Inhabits Cumberland river near Nashville, Tennessee, and Elk river, near the muscle shoals, Alabama.

In outline it somewhat resembles Unio lineolatus, but more nearly approaches the penitus. The rays, very wide umbo, and the proportionally shorter outline distinguish it from the latter species. The lower figure represents the female.

\section{UNIO PLEXUS.}

Plate XlaIX.-Figs. 1, 2.

DESCRIPTION.

Shell suboval, ventricose; posterior margin truncated or obtusely rounded; posterior slope with narrow ribs; umbo flattened, with longitudinal undulations; umbonial slope subangulated; beaks eroded, not prominent; epidermis nearly black, wrinkled; within purple; cardinal teeth direct; anterior muscular impression very rough.

Cab. A. N. S., No. 20421.

OBSERVATIONS.

This species was sent from Vera Cruz by the American consul, Dr. Marmaduke Burrough. I am unacquainted with its habitat. The larger specimen, of which an outline is given on the plate, much resembles $U$. niger, but the undulations on the umbones, the proportional length in the smaller speci- 
men, and other characters, render it sufficiently distinct. It has, perhaps, more general resemblance to Unio trapezoides than to any other species.

\section{UNIO HETERODON.}

Plate XLIX.-Fig. 3.

DESCRIPTION.

Shell rhomboidal-ovate, ventricose, valves thin; ligament margin short, elevated, parallel with the basal margin; umbonial slope rounded; beaks decorticated; basal margin straight in the middle; posterior extremity rounded or very obtusely angulated, a little above the line of the base; within bluish; cardinal tooth in the left valve trilobed; in the right valve, single, elongated, oblique, compressed; lateral teeth slightly curved, double in the right valve.

\section{SYNONYME.}

U. heterodon, Lea. Trans. Amer. Phil. Soc., new series, vol. iii. p. 428, pl. viii. fig. 11 .

Cab. A. N. S., No. 20425.

\section{OBSERVATIONS.}

Inhabits the Schuylkill and other rivers in Pennsylvania. This interesting little species was first found by Messrs. Mason and Hyde, and my father suggested the name of heterodon, which Mr. Lea has adopted. It is related to $U$. viridis and compressus, but the double cardinal teeth being in the right valve will distinguish it from every other species. 


\section{UNIO LIENOSUS.}

VARIETY CONSTRICTUS.

Piate XLIX.-Fig. 4.

DESCRIPTION.

Shell elliptical, ventricose; beaks rather prominent, undulated, distant from the anterior margin; posterior side furrowed, contracted at base; posterior angle much above the line of the base; epidermis obscurely rayed; within white; cardinal teeth robust.

Cab. A. N. S., No. 20423.

OBSERVATIONS.

Inhabits North river, Rockbridge county, Virginia. Several specimens of this variety exhibit the peculiar groove on the posterior side, which has suggested the name. . In other respects it agrees with $\boldsymbol{U}$. lineosus of the south-western streams, except that the cardinal teeth are more robust.

\section{UNIO STRAMINEUS.}

Plate L.-Fig. 1.

DESCRIPTION.

Shell ovate, ventricose; disk with coarse prominent lines of growth; umbo with numerous undulated plicæ; umbonial slope undefined; ligament margin elevated; 
anterior side slightly contracted or furrowed from beak to base; basal margin slightly emarginate; epidermis straw-coloured, polished; within white; cardinal teeth double in each valve; lateral teeth slightly arcuate.

SYNONYME.

U. stramineus, Nob. New Fresh Water Shells, pl. vii. fig. 3. Cab. A. N. S., No. 20420.

OBSERVATIONS.

Inhabits brooks or mill streams in Greene county, Alabama.

This species may be compared to some varieties of siliquoideus, but is sufficiently distinct, being destitute of rays on the disk, and having remarkably prominent lines of growth. The siliquoideus has not been found in Alabama.

\section{UNIO PATULUS.}

\section{Plate L.-Fig. 2.}

DESCRIPTION.

Shell ovate; convex anteriorly, and compressed and cuneiform posteriorly; substance of the shell thick on the anterior and thin on the posterior side; beaks not terminal, prominent, undulated, almost contiguous; umbonial slope undefined or obtusely rounded; epidermis brownish-yellow, with broad interrupted green rays composed of fasciculi of hair like lines; within white; cardinal teeth, in the left valve pro- 
50
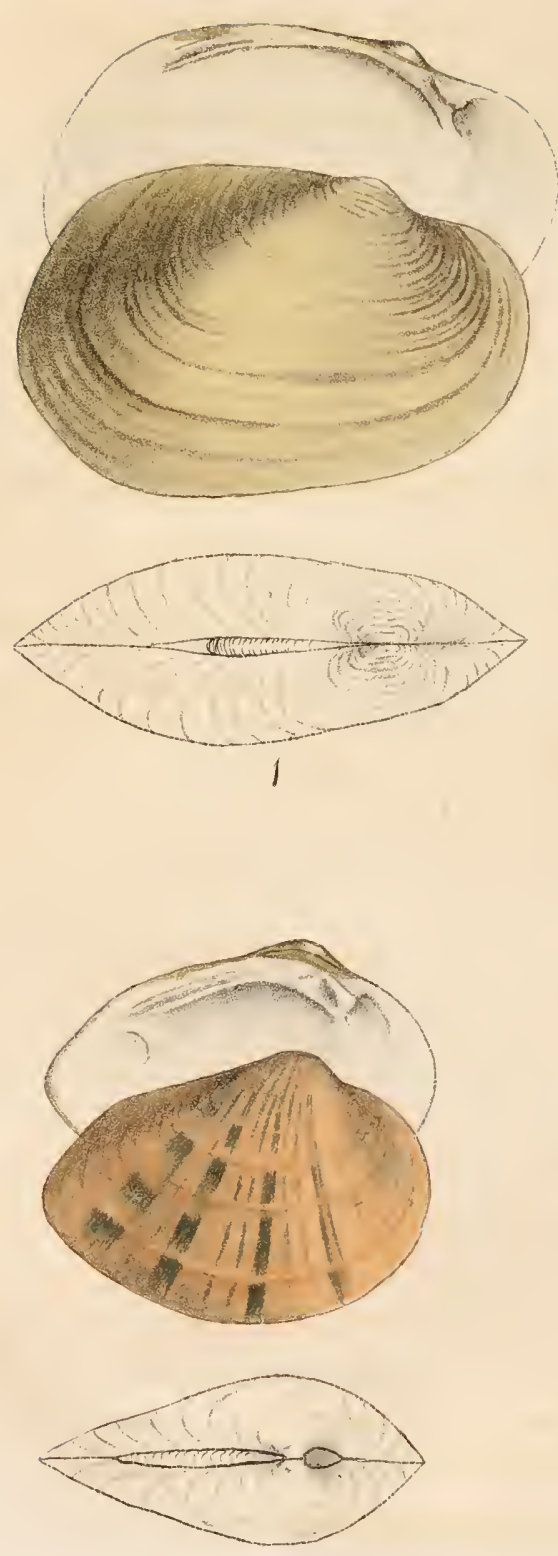

2

1.U. strainineus, c: 2. L' putulus, loca o 


.) 1
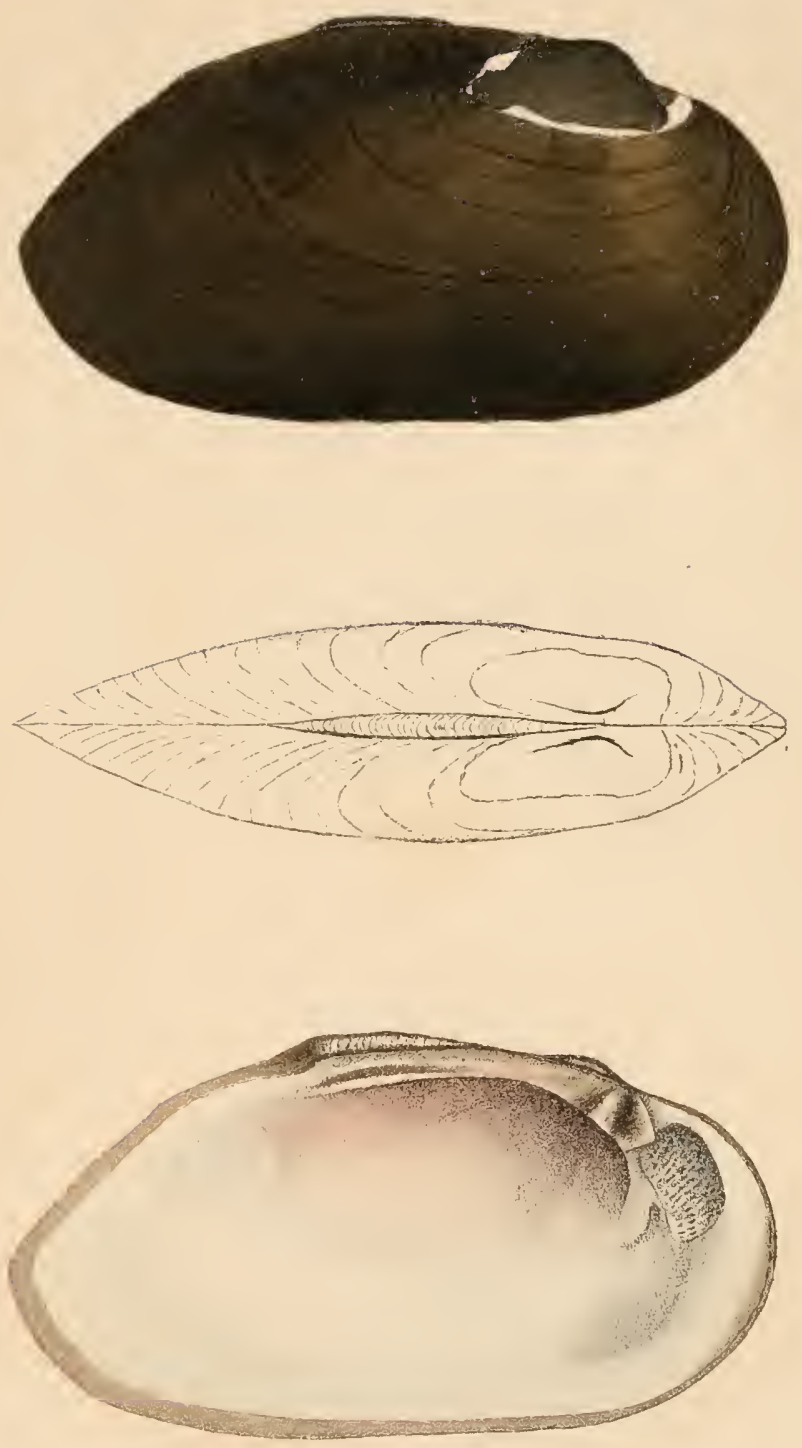

Umer) Hembele, Conrosel. 
foundly diverging; in the right valve single, robust, sulcated; lateral teeth rectilinear.

\section{SYNONYME.}

U. Patulus, Lea. 'Trans. Amer. Phil. Soc., new series, vol.iii. p. 441, pl. xii. fig. 20.

Cab. A. N. S., No. 20424.

OBSERVATIONS.

Inhabits the rivers of Tennessee and Kentucky, and appears to be comparatively rare. It may be distinguished from $U$. clava by its less oblique and more compressed form; and the beaks are less prominent and not terminal. The beaks are acutely pointed at the apex, and nearly touch each other; and they are somewhat flattened on the summit and have tubercular undulations. It is probable that $U$. oviformis is but a variety of this species.

\section{UNIO HEMBELI.}

Plate Li.-Fig. 1.

DESCRIPTION.

Shell elliptical, convex, posterior extremity angular, much above the line of the base; posterior slope with obtuse undulations; beaks eroded, scarcely elevated above the dorsal line; umbonial slope undefined; epidermis dark brown, becoming black with age, much wrinkled; within white; cardinal teeth robust, double in each valve, direct, profoundly striated.

Cab. A. N. S., No. 20422. 
OBSERVATIONS.

Many specimens of this shell was sent from New Orleans in company with the declivis, Mortoni, purpuratus, \&c., but the locality was not given. It has some affinity with the subtentus, but is thinner in substance, and differs widely in the posterior angle. It is never rayed, whilst that species has well marked interrupted rays. Some specimens which are destitute of the undulations on the posterior slope might be confounded with $\boldsymbol{U}$. complanatus.

It is named in compliment to my friend William Hembel, Esq., Vice-President of the Academy of Natural Sciences of Philadelphia. 


\section{N D E X .}

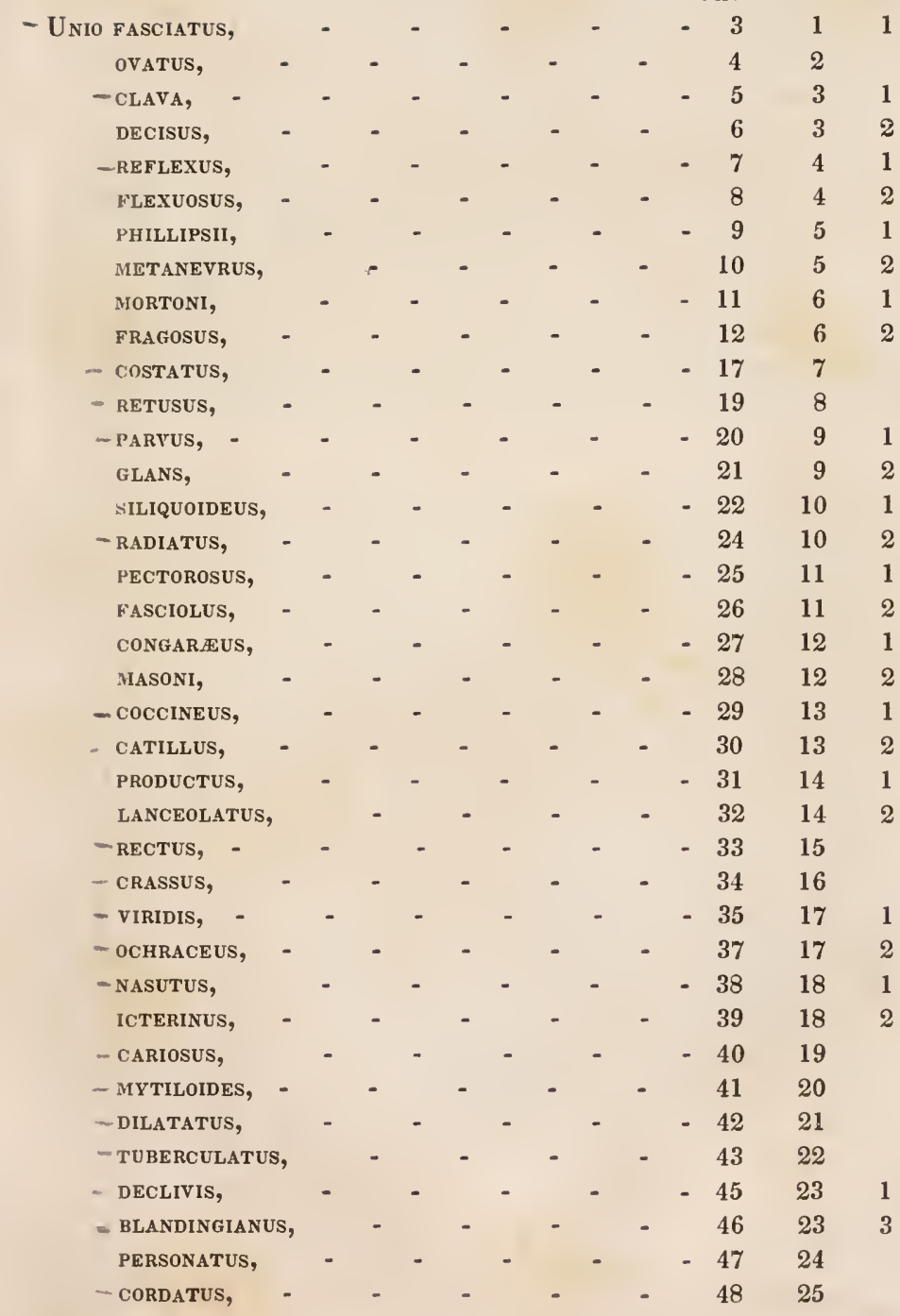




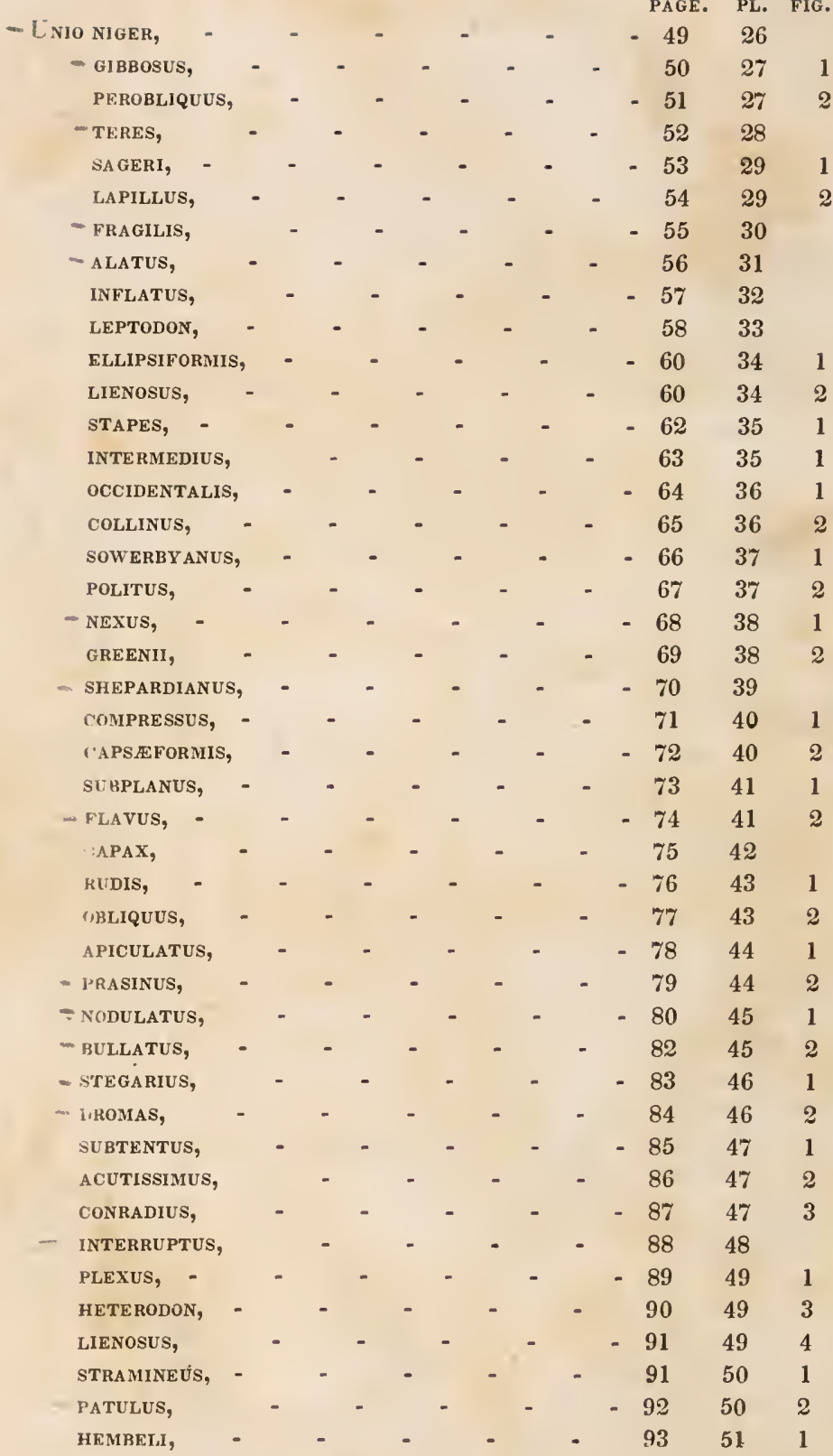




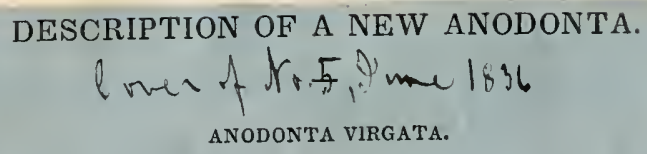

Description.

Shelì subovate, thin and fragile, inflated; umbo prominent, distant from the anterior extremity; beaks pointed, incurved, undulated; umbonial slope angulated; posterior margin arcuate, extremity angulated; basal margin dilated posteriorly; within bluish and iridescent; cavity very capacious.

\section{Observations.}

This pretty Anodonta is related to $A$. undulata, $\mathrm{S}_{\mathrm{AY}}$, but can be known by the posterior dilatation of the basal margin, which inclines the outline to an ovate form, and by the rays, which are very numerous and unequal, of a beautiful dark green, or the epidermis is green with narrow pale rays, and much resembles Anodonta radiata, nob.; it is comparatively shorter than that species.

This species was afforded me for description by Dr. Jacob Green, Professor of Chemistry in Jefferson College. Mr. William Mason has specimens from Buck Creek, Clarke county, Ohio.

$V_{4} y$ DESCRIPTION OF A NEW ANADONTA.

Shell narrow, elliptical, compressed, thin and fragile; anterior side narrow, rounded at the extremity; posterior side produced, subcuneiform, truncated at the extremity; hinge margin long, straight, elevated or slightly ascending, from anterior to the posterior extremity; beaks not elevated above the dorsal line; basal margin straight in the middle; colour of epider mis olive-green inferiorly, darker above; hinge margin without a callous. Lengtli, $2 \frac{1}{2}$ inches; height, $1 \frac{1}{8}$ inch. Inhabits rivers in Kentucky.

This species is in the fine collection of my friend Mr. John Phillips, who informs me that it is from the Ohio or one of its tributaries below Louisville. It has much the outline of Unio carinifera of Lam. (the common variety of $U$. complanatus, ) but is proportionally more elongated, and the posterior extremity resembles that of Unio declivis, except that it is truncated at the tip.

Unio gibbosus, var. perobliquus, pl. xxvii. fig. 2, I have ascertained to be a species; it will therefore take the name of Unio perobliguns. 










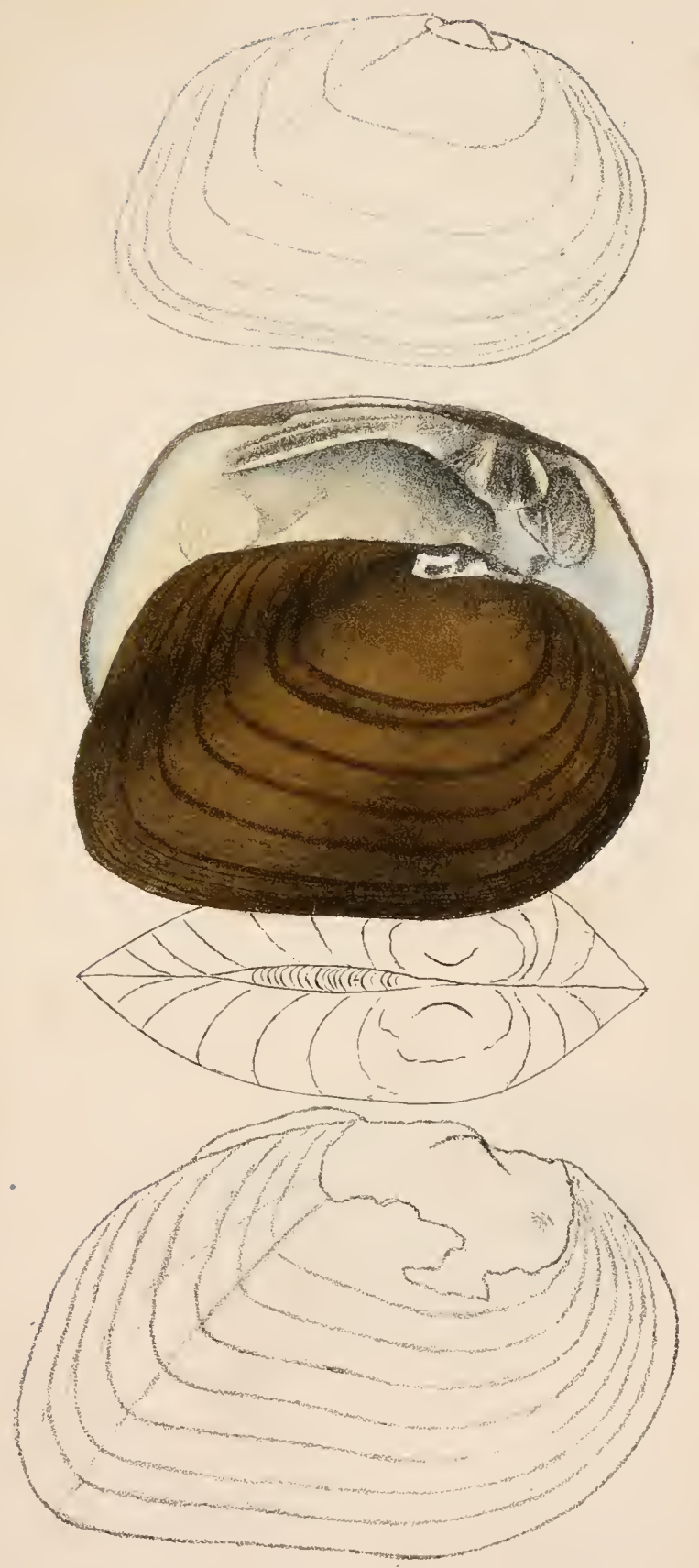

Unio eserinus, Coutud. 

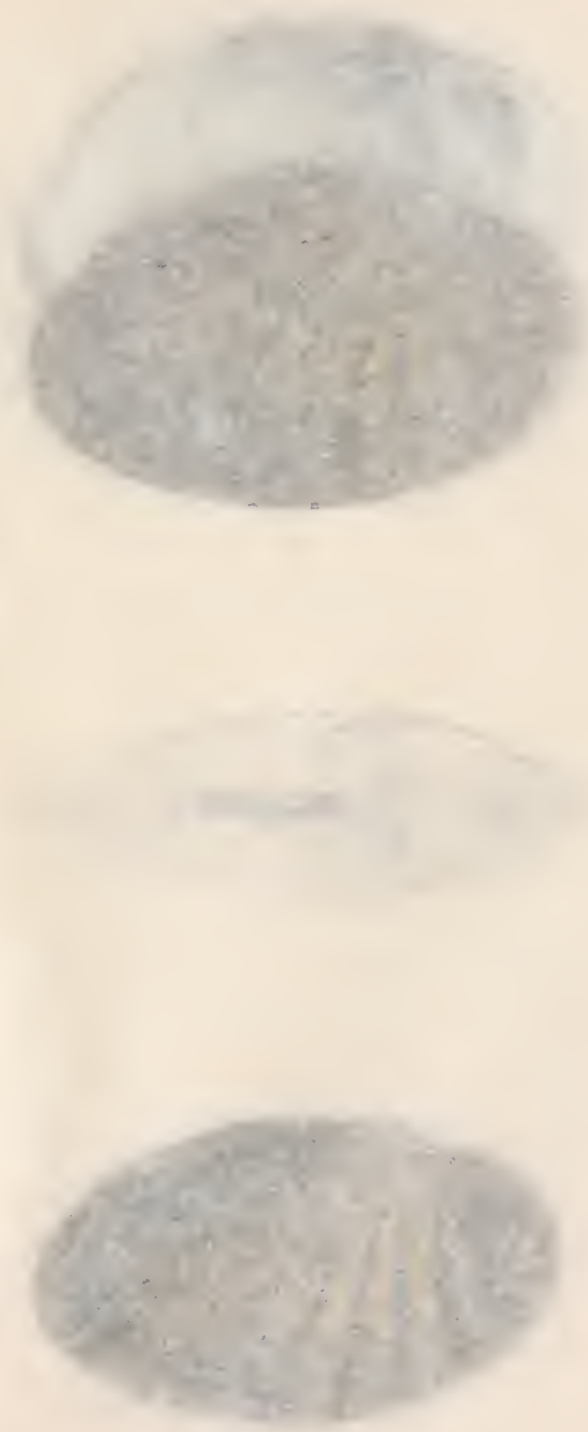


\section{5}
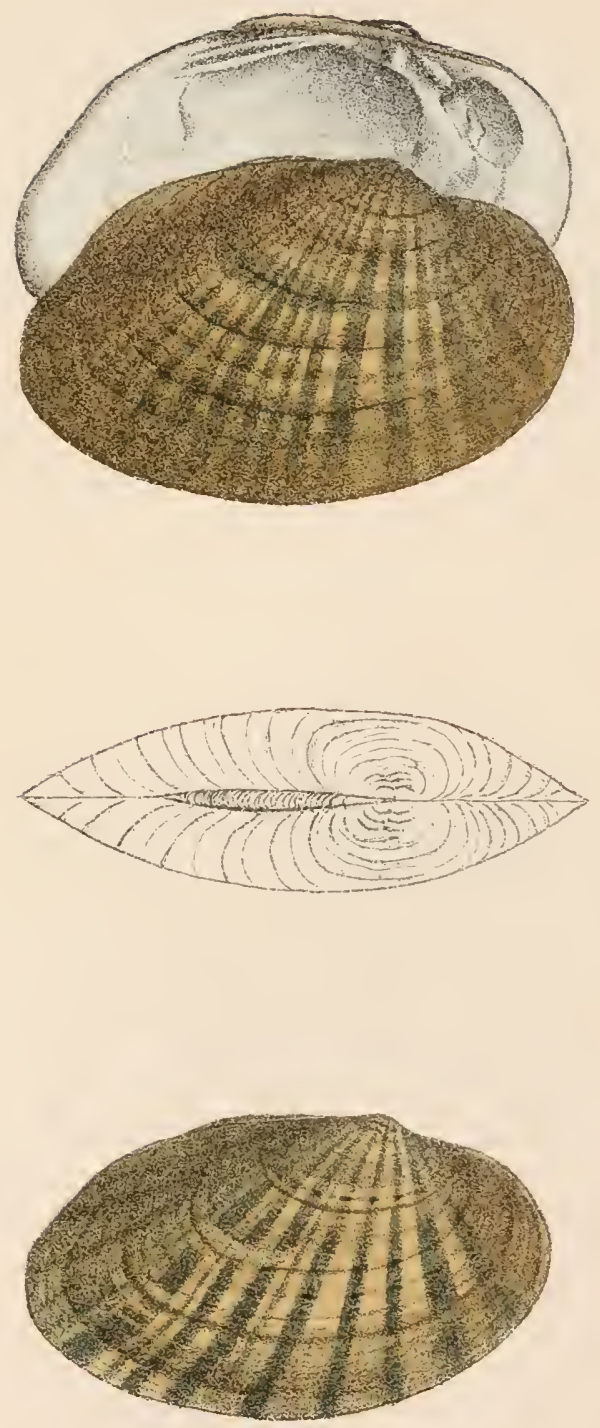

Inio Latirudirtus, Con. 

54
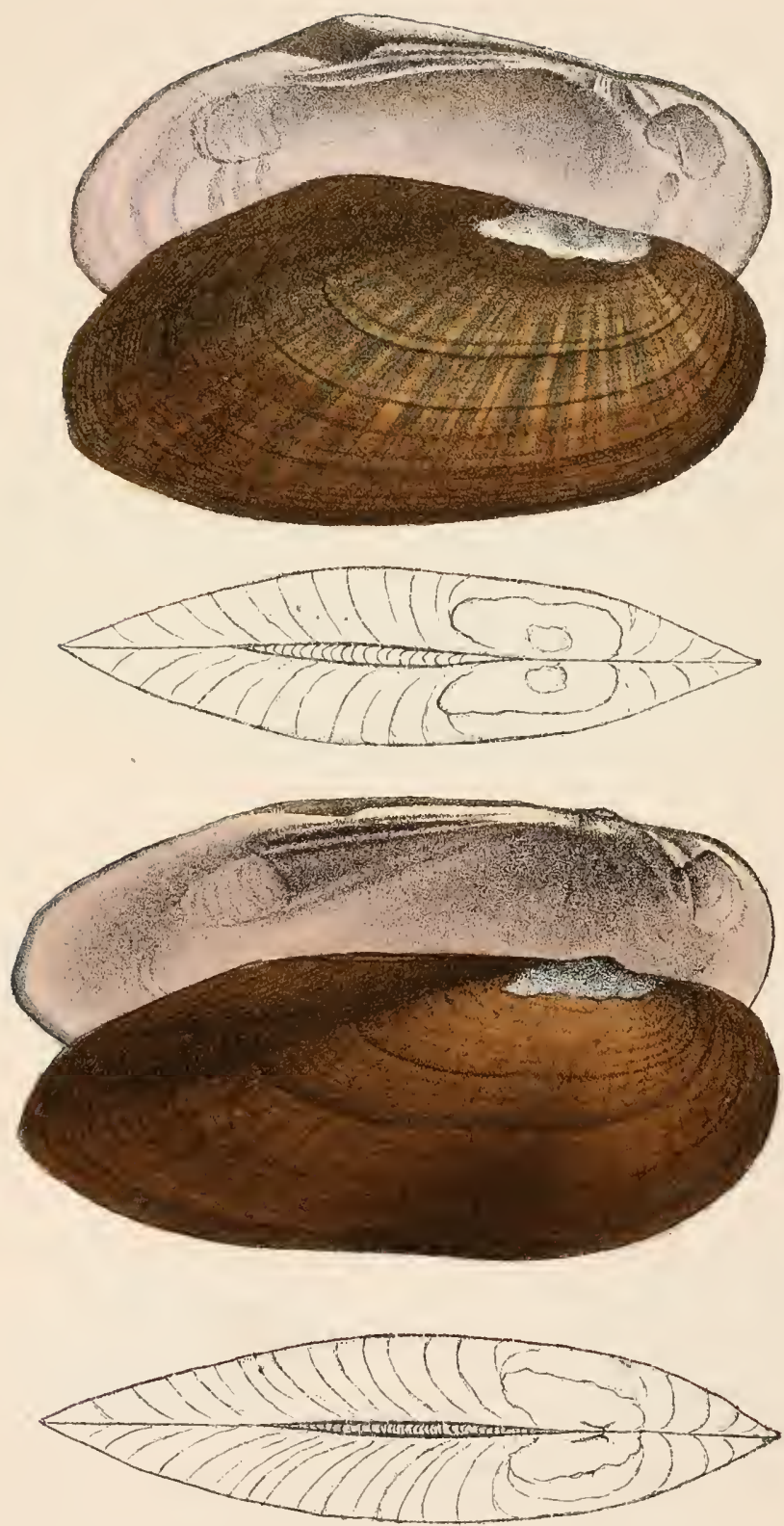

1. Uruis subinflatus, C. 2. IJ angustatus; Lex. 

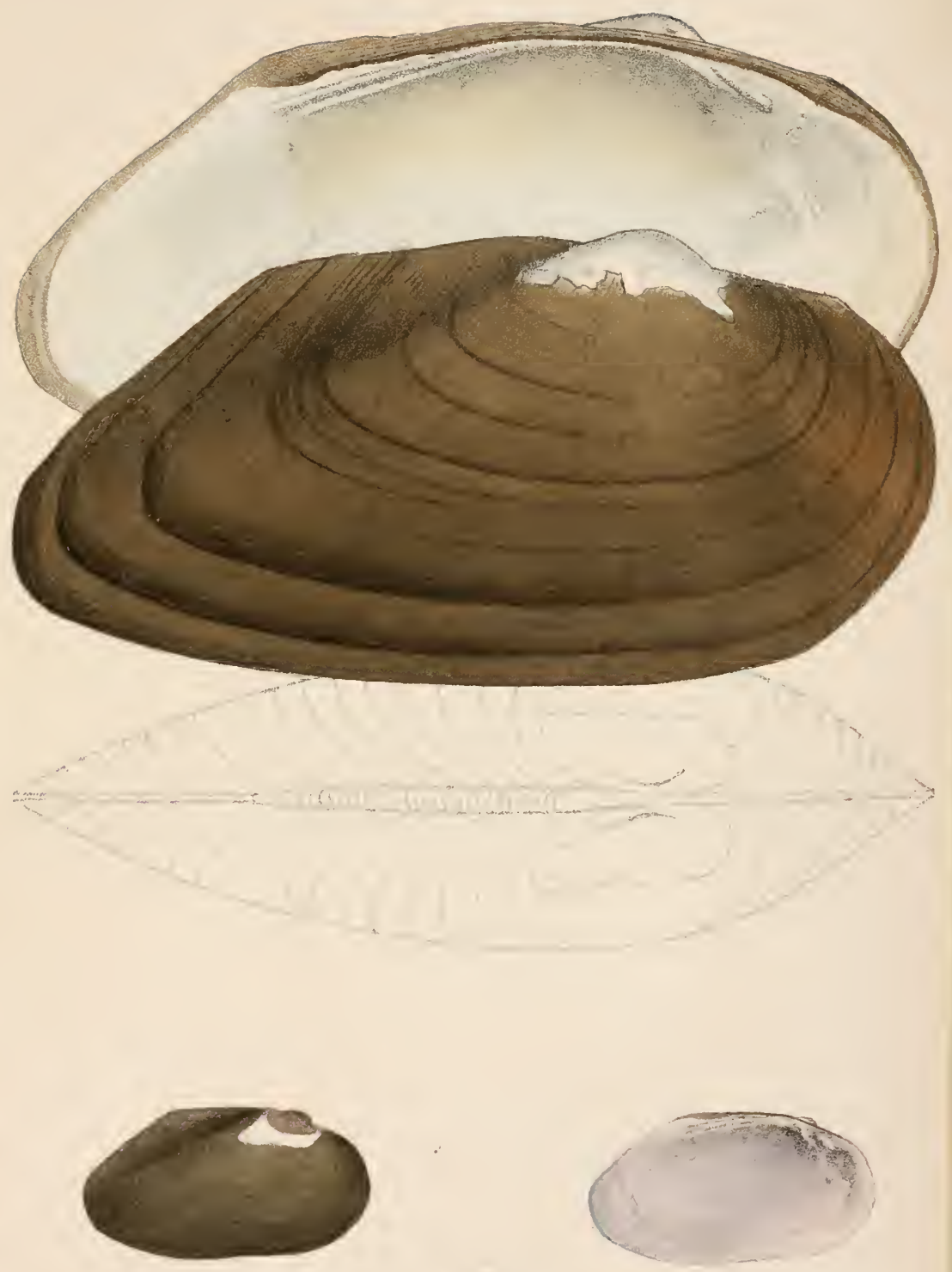

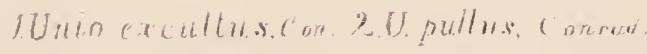








